\title{
Epigenetic geochemical dynamics and driving mechanisms of chemical elemental distribution patterns in soil in Southwest China*
}

\author{
(c) Hangxin Cheng ${ }^{\mathrm{a}}$, Min Peng ${ }^{\mathrm{b}}$, Chuandong Zhaoc, Wei Hand, Huiyan Wange, \\ Qiaolin Wang ${ }^{f}$, Fan Yang ${ }^{g}$, Fugui Zhang ${ }^{\mathrm{h}}$, Chengwen Wangi, Fei Liuj, \\ Yalong Zhouk, Shiqi Tang', Kuo Li ${ }^{\mathrm{m}}$, Ke Yang ${ }^{\mathrm{n}}$, Zheng Yang ${ }^{\circ}$, \\ Xiaomeng Cheng ${ }^{p}$, Ziwan Chen ${ }^{q}$, Hua Zhang ${ }^{r}$, Chunhu Mos \\ a-p Institute of Geophysical \& Geochemical Exploration, \\ Chinese Academy of Geological Sciences, Langfang, China \\ ${ }^{b}$ China University of Geosciences (Beijing), Beijing, China \\ aYunnan Institute of Geological Survey, Kunming, China \\ rSichuan Geological Survey, Chengdu, China \\ ${ }^{s}$ Guizhou Geological Survey, Guiyang, China
}

\begin{abstract}
The Earth's surface is a complex system involving mutual interactions of its many components, including mountains, rivers, forests, farmlands, lakes and grasses. The interaction and mutual feedback of chemical elements in Earth's surface layer can drive changes in chemical elemental distribution patterns. In this study, we evaluated the mechanisms and interactions driving the distribution patterns of macroelements, probiotics, halogens and heavy metals in soils in Southwest China, based on a systematic geochemical land-quality survey at a scale of 1:250000. The results showed that the parent material determines the natural state of chemical elements in land resources. Epigenetic geochemical dynamics reshapes the distribution patterns of chemical elements in top soil; biogeochemical processes drive the evolutionary trends of land quality; and human activities, such as mining, disrupt the natural evolution of chemical elemental distribution patterns. The establishment of an epigenetic geochemical dynamics theory allows the construction of a framework for understanding the Earth's surface layer and promoting technological innovations for the comprehensive geochemical investigation of land resources.
\end{abstract}

Keywords: epigenetic geochemical dynamics, driving mechanisms, distribution pattern of elements in soils, Southwest China

Acknowledgments: During the project, more than 100 researchers and workers from the Yunnan Geological Survey, Sichuan Geological Survey and Guizhou Geological Survey participated in the field work. More than 20 researchers from the Central Laboratory of the Institute of Geophysical and Geochemical Exploration of the Chinese Academy of Geological Sciences participated in the sample analysis and testing processes. The authors would like to thank all participants for their contributions to this work.

Information about the article: Received July 08, 2020; revised August 10, 2020; accepted September 04, 2020.

For citation: Cheng Hangxin, Peng Min, Zhao Chuandong, Han Wei, Wang Huiyan, Wang Qiaolin, et al. Epigenetic geochemical dynamics and driving mechanisms of chemical elemental distribution patterns in soil in Southwest China. Nauki o Zemle i nedropol'zovanie = Earth sciences and subsoil use. 2020;43(3):375-417. (In Russ.) https://doi.org/10.21285/2686-9993-2020-43-3-375-417

\footnotetext{
"The article was provided by the Earth Science Frontiers journal within the framework of the agreement between the editorial boards of Irkutsk National Research Technical University (Irkutsk, Russia) and China University of Geosciences (Beijing, China) on the exchange of open access scientific papers.
} 


\title{
Эпигенетическая геохимическая динамика и движущие механизмы закономерностей распределения химических элементов в почвах Юга-Западного Китая*
}

\author{
(c) Хансинь Чэн ${ }^{a}$, Минь Пэн ${ }^{b}$, Чуаньдун Чжаос, Вэй Хань ${ }^{d}$, Хуйянь Ван $^{\mathrm{e}}$, \\ Цяолинь Ван ${ }^{f}$, Фань Ян ${ }^{g}$, Фугуй Чжан ${ }^{\mathrm{h}}$, Чэнвэнь Ван \\ Ялун Чжоу, Шици Тан', Ко Лит ${ }^{\mathrm{m}}$, Кэ Ян ${ }^{\mathrm{n}}$, Чжэн Яно \\ Сяомэн Чэн ${ }^{p}$, Цзывань Чэнь ${ }^{q}$, Хуа Чжан ${ }^{r}$, Чуньху Mos \\ a-рИнститут геофризических и геохимических исследований \\ Китайской академии геологических наук, г. Ланфран, Китай

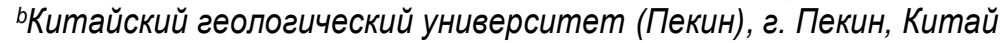 \\ яюньнаньский институт Геологической службы, г. Куньмин, Китай \\ 'Сычуаньская геологическая служба, г. Чэнду, Китай \\ sГеологическая служба Гуйчжоу, г. Гуйян, Китай
}

\begin{abstract}
Резюме: Поверхность Земли представляет собой сложную систему, включающую взаимодействие многих ее компонентов, в том числе гор, рек, лесов, сельскохозяйственных угодий, озер и трав. Взаимодействие и взаимная обратная связь химических элементов в поверхностном слое Земли может привести к изменениям в структуре распределения химических элементов. В этом исследовании авторы оценили механизмы и взаимодействия, определяющие характер распределения макроэлементов, пробиотиков, галогенов и тяжелых металлов в почвах ЮгоЗападного Китая, на основе систематического геохимического исследования качества земли в масштабе 1:250000. Результаты показали, что исходный материал определяет естественное состояние химических элементов земельных ресурсов. Эпигенетическая геохимическая динамика меняет характер распределения химических элементов в верхнем слое почвы, биогеохимические процессы определяют эволюционные тенденции качества земли, а деятельность человека, такая как добыча полезных ископаемых, нарушает естественную эволюционную схему распределения химических элементов. Создание теории эпигенетической геохимической динамики позволяет построить основу для понимания поверхностного слоя Земли и продвигать инновационные технологии для всестороннего геохимического исследования ресурсов земной коры.
\end{abstract}

Ключевые слова: эпигенетическая геохимическая динамика, движущие механизмы, закономерности распределения элементов в почвах, Юго-Западный Китай

Благодарности: В процессе реализации проекта более ста исследователей и сотрудников из геологических служб провинций Юньнань, Сычуань и Гуйчжоу принимали участие в полевых работах. Более двадцати ученых из Центральной лаборатории Института геофизических и геохимических исследований Китайской академии геологических наук были привлечены к анализу и тестированию собранных образцов. Авторы хотели бы поблагодарить всех участников за их вклад в эту работу.

Информация о статье: Поступила в редакцию 08 июля 2020 г.; поступила после рецензирования и доработки 10 августа 2020 г.; принята к публикации 04 сентября 2020 г.

Для цитирования: Чэн Хансинь, Пэн Минь, Чжао Чуаньдун, Хань Вэй, Ван Хуйянь, Ван Цяолинь [и др.]. Эпигенетическая геохимическая динамика и движущие механизмы закономерностей распределения химических элементов в почвах Юга-Западного Китая. Науки о Земле и недропользование. 2020. Т. 43. № 3. С. 375-417. https://doi.org/10.21285/2686-9993-2020-43-3-375-417

\section{Background}

Epigenetic geochemical dynamics explores the driving mechanisms, dynamic processes, and fractionation mechanisms of the distribution, allocation, migration and evolution of chemical elements and isotopes in surface rocks, water bodies, soils, organisms, atmosphere and other media or layers of the Earth. The Earth's surface is a complex system composed of various interact- ing components, such as mountains, water bodies, forests, farmlands, lakes and grasslands. This system controls and regulates the natural habitat and maintains the resources required to sustain life on Earth [1]. The pedosphere is the key interface, at which the lithosphere, hydrosphere, biosphere and atmosphere interact. It plays an important role in the redistribution of elements, and is also an essential interface for

* Статья была предоставлена редакцией журнала Earth Science Frontiers в рамках соглашения между редакциями Иркутского национального исследовательского технического университета (г. Иркутск, Россия) и Китайского геологического университета (г. Пекин, Китай) об обмене научными статьями открытого доступа. 
supporting economic and social developments [2]. Presently, the Earth is facing a serious environmental crisis in history. This has caused dysfunction in the Earth's surface layer and led to major changes in the global environment on which human survival depends. Understanding the behavior of chemical elements within the physical, chemical and biological processes of the Earth's surface, along with human-environmental interactions, has inevitably become a hot topic in exploratory geochemistry. Research in this area can reveal the driving mechanisms behind changes in the content and macroscopic distribution of elements in soil, thereby provide scientific solutions for the rational exploitation and utilization of natural resources.

In this study, we analyzed the mountainous regions near several cities including Zhaotong City in Yunnan Province, Bijie City in Guizhou Province, and Yibin and Luzhou Cities in Sichuan Province, and examined the driving mechanisms of chemical elemental distribution in soil.

\section{Geographical and geological settings}

The study area is located at the junction of Yunnan, Guizhou and Sichuan Provinces (102- $107^{\circ} \mathrm{E}$ and $\left.25-30^{\circ} \mathrm{N}\right)$. The geographical environment of the area is complex, with different climate types co-existing at different elevations, and with significant regional variations. In the last 45 years, the average annual precipitation of the area was $1,885 \mathrm{~mm}$, while temperature, precipitation and evaporation are increasing $[3,4]$.

The study area mainly consists of mountains and valleys, showing strong down-cutting and Karst landforms. The terrain slopes northwards, as behind elevation lowers gradually from the southwest to the northeast by a difference of greater than $3,400 \mathrm{~m}$ (Fig. 1). Farmlands, forests and grasslands accounted for $48.8 \%, 41.4 \%$ and $5.2 \%$ of the total area of the region, respectively, and they represent the major land-use types in the region (Fig. 2).

All strata in the area have different degrees of exposure, where carbonate rocks, such as limestone and dolomite, from various periods, are widely distributed. Basalt, carbonate and sedimentary clastic rocks are the main parent materials of the regional soil (Fig. 3).

Lead $(\mathrm{Pb})$, zinc $(\mathrm{Zn})$ and silver $(\mathrm{Ag})$ constitute the area's dominant mineral resources formed in the Devonian and Permian periods. The ores are

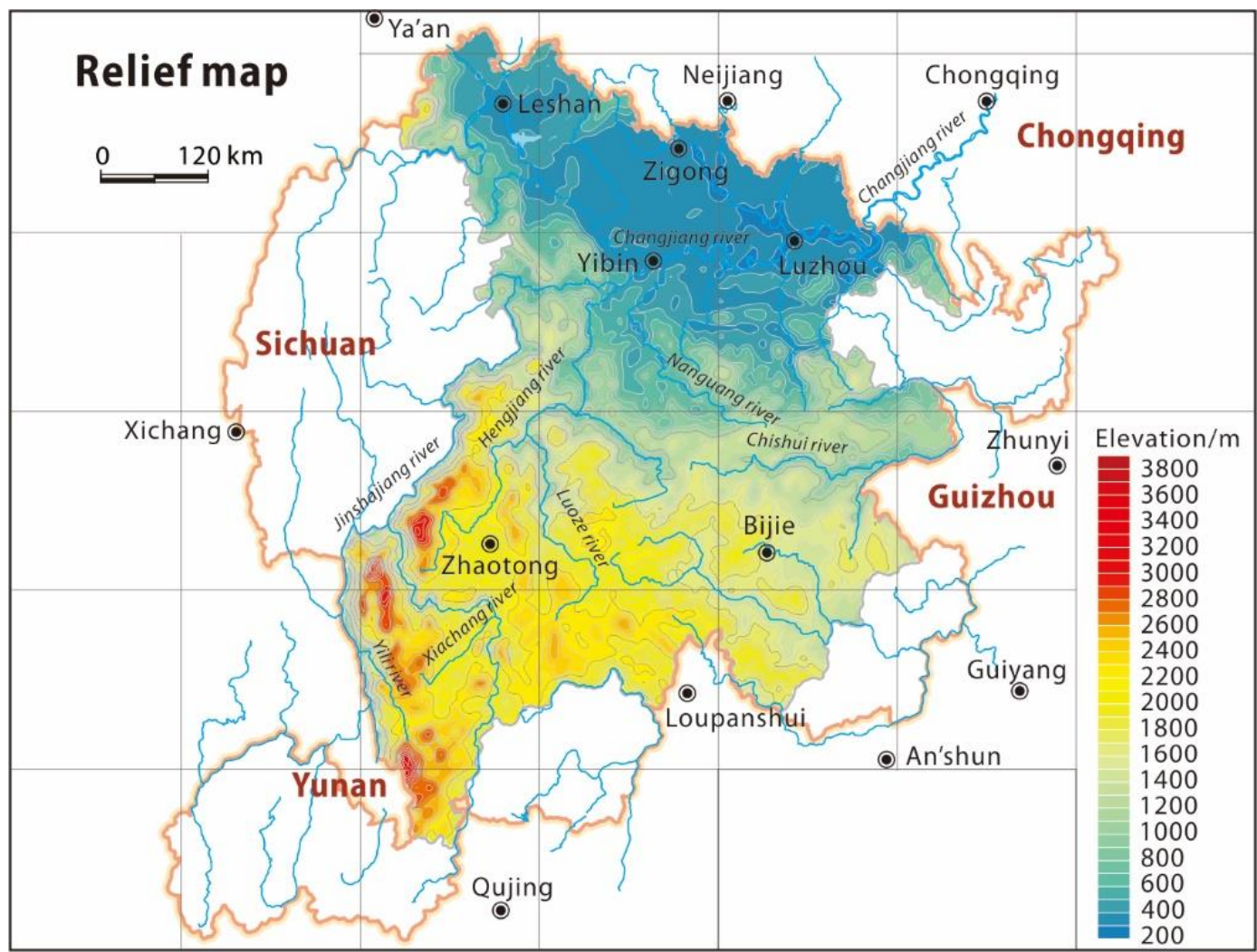

Fig. 1. Terrain distribution in the Zhaotong - Bijie - Yibin - Leshan - Luzhou area

Рuc. 1. Распределение высот рельефа в районе Чжаотун - Бицзе - Ибинь - Лэшань - Лучжоу 


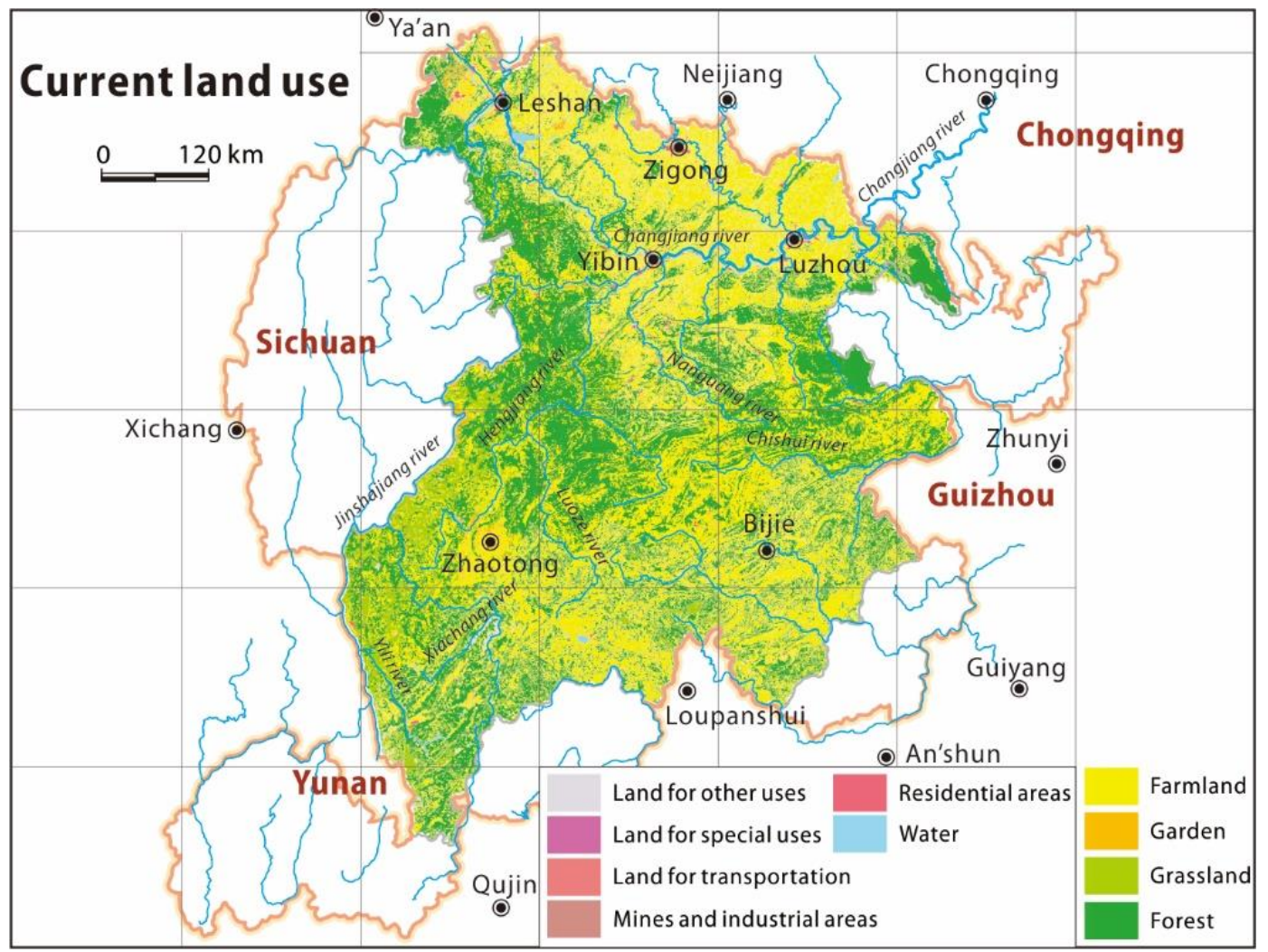

Fig. 2. Land-use types in the Zhaotong - Bijie - Yibin - Leshan - Luzhou area

Puc. 2. Типы землепользования в районе Чжаотун - Бицзе - Ибинь - Лэшань - Лучжоу

usually present in carbonaceous strata, comprising interbedded dolomite, dolomitic limestone, limestone and marl in the area. The area also features paragenetic or associated non-ferrous, rare and precious metal elements such as copper $(\mathrm{Cu})$, iron ( $\mathrm{Fe}$ ), silver, gallium (Ga), cadmium (Cd) and germanium $(\mathrm{Ge})[5,6]$.

Basalt, carbonate and $\mathrm{Pb}-\mathrm{Zn}-\mathrm{Ag}$ deposits are mainly distributed in the mid- and high-elevation mountainous areas above $1,000 \mathrm{~m}$ (Fig. 3). The Emeishan large igneous province (LIP) resulted from a mantle-plume melting event spanning less than $1 \mathrm{Ma}$ at approximately $259 \mathrm{Ma}$ [7]. Spatially, Emeishan basalt is mainly distributed in Yunnan, Sichuan and Guizhou Provinces along the western margin of the Yangtze Craton. This region extends to Guangxi and Chongqing in the east and is bordered by the Ailaoshan - Red River fault to the west and the Longmenshan - Xiaojing River fault to the northwest. As it is near the Sanjiang tectonic belt, the Emeishan LIP's complex geological history includes strong deformation and destructive events that resulted in approximately $0.25 \cdot 10^{6} \mathrm{~km}^{2}$ exposed area. The basalt in the study area is located within the continental rift system in the Emeishan basalt zone [8], where the exposed area covered approximately 8,867 $\mathrm{km}^{2}$ (Fig. 3) or approximately $10.46 \%$ of the total study region; while the exposed carbonate rocks covered $20,934 \mathrm{~km}^{2}$ or approximately $24.70 \%$ of the study area.

The Geochemical Atlas of China ${ }^{1,2}$ and the Geochemical Survey Report of Chinese Farmland ${ }^{3}$ clear show abnormal enrichment of metal elements in the soil and stream sediments in the Emeishan basalt and the southwestern carbonate areas. These areas have high metallic elemental contents relative to elsewhere in China.

Therefore, it is essential to study the epigenetic geochemical processes in these areas and the impact of $\mathrm{Pb}$ and $\mathrm{Zn}$ mining activities on the regional elemental distribution. The findings

\footnotetext{
${ }^{1}$ Xie X., Ren T., Sun H. Geochemical atlas of China. Beijing: Geological Publishing House, 2012. 120 p.

${ }^{2}$ Xie X., Cheng Z., Zhang L., et al. Geochemical atlas of 76 elements in Southwest China. Beijing: Geological Publishing House, 2008. 219 p.

${ }^{3}$ China Geological Survey. Geochemical survey report on China's cultivated land (2015). Available from: http://www.cgs.gov.cn/upload/201506/20150626/gdbg.pdf [Accessed 25 June 2015].
} 


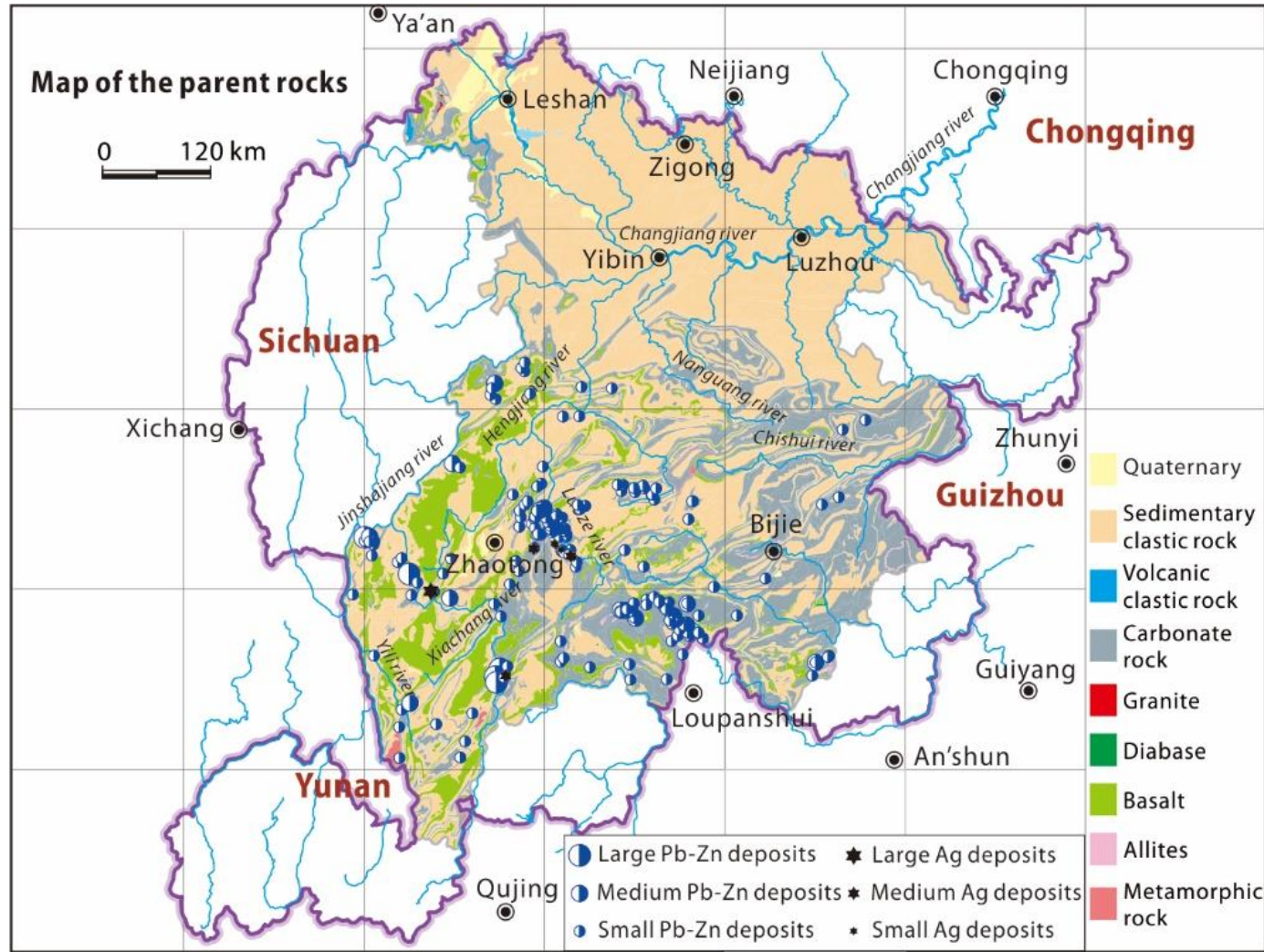

Fig. 3. Distribution map of the parent materials and Pb-Zn-Ag deposits in the Zhaotong - Bijie - Yibin - Leshan - Luzhou area

Puc. 3. Карта распределения материнских горных пород и месторождений Pb-Zn-Ag в районе Чжаотун - Бицзе - Ибинь - Лэшань - Лучжоу

can facilitate the advancements of the theories of epigenetic geochemical dynamics, as well as development of geochemical surveys and monitoring systems for land resources, and applications of exploratory geochemistry in natural resource management.

\section{Data sources}

The data used in this study were obtained through tests in accordance with the "Multi-Purpose Regional Geochemical Survey" specifications $(1: 250,000)$ (DZ/T 0258-2014) ${ }^{4}$. The sampling depths of the top and deep soil samples were 0-20 cm and $150-180 \mathrm{~cm}$, respectively. The samples were analyzed in the Central Laboratory of the Institute of Geophysical and Geochemical Exploration, Chinese Academy of Geological Sciences. The tested elements and indicators included $\mathrm{Ag}, \mathrm{As}, \mathrm{Au}, \mathrm{B}, \mathrm{Ba}, \mathrm{Be}, \mathrm{Bi}, \mathrm{Br}, \mathrm{Cd}$, $\mathrm{Ce}, \mathrm{Cl}, \mathrm{Co}, \mathrm{Cr}, \mathrm{Cu}, \mathrm{F}, \mathrm{Ga}, \mathrm{Ge}, \mathrm{Hg}, \mathrm{I}, \mathrm{La}, \mathrm{Li}, \mathrm{Mn}$, $\mathrm{Mo}, \mathrm{N}, \mathrm{Nb}, \mathrm{Ni}, \mathrm{P}, \mathrm{Pb}, \mathrm{Rb}, \mathrm{S}, \mathrm{Sb}, \mathrm{Sc}, \mathrm{Se}, \mathrm{Sn}, \mathrm{Sr}$,
Th, Ti, TI, U, V, W, Y, Zn, Zr, $\mathrm{SiO}_{2}, \mathrm{Al}_{2} \mathrm{O}_{3}, \mathrm{TFe}_{2} \mathrm{O}_{3}$, $\mathrm{MgO}, \mathrm{CaO}, \mathrm{Na}_{2} \mathrm{O}, \mathrm{K}_{2} \mathrm{O}, \mathrm{TC}$, organic carbon (Corg) and $\mathrm{pH}$. The schemes for analysis and quality control used in this study are as described in the references [9]. A quality assessment of the data, analyzed according to the prescribed procedures, showed that the data are reliable and passed the acceptance and database audits.

\section{Mechanisms driving the macroscopic distribution of major elements}

During complex physical and chemical weathering processes, soil parent materials can form in-situ residual soil. Alluvial and proluvial soils may also appear in downstream areas due to transportation and sedimentation processes when slopes and rivers are present. Deep soil is less affected by industrial and agricultural activities, in which elemental distribution is mainly controlled geologically. Typically, when there is no significant impact from human activities, the

${ }^{4}$ Ministry of Land and Resources of the People's Republic of China. Code for multi-target regional geochemical surveys (1:250000) (DZ/T 0258-2014). Beijing: China Standard Press, 2015. 43 p. 
elemental distribution patterns of the top soil reflects that of the deep soil. However, owing to the extensive and frequent contacts between the top soil and atmosphere, water bodies, organisms or human beings, the elemental distribution patterns in soil can be considerably modified. Emeishan basalt and carbonate rocks are the two most common soil parent materials in the study area. The dynamic processes of surface erosion, transportation and sedimentation, caused by marked elevation changes and biogeochemical effects of extensive forests, are a starting point for characterizing the mechanisms driving the macroscopic distribution of elements in this region.

Main weathering and soil formation processes of basalt and carbonate rocks. Emeishan basalt is mainly composed of basic plagioclase and pyroxene minerals with some olivine, amphibole and biotite. In an epigenetic environment, the physical weathering processes drive basic feldspar ( $\mathrm{Na}\left[\mathrm{AlSi}_{3} \mathrm{O}_{8}\right]-\mathrm{Ca}\left[\mathrm{Al}_{2} \mathrm{Si}_{2} \mathrm{O}_{8}\right]$ ) to fracture along the cleavage planes. Further, the chemical weathering processes cause basic feldspar decomposition, i.e., basic feldspar $\rightarrow$ hydromica $+\mathrm{K}^{+}, \mathrm{Na}^{+}, \mathrm{Ca}^{2+} \rightarrow$ kaolinite (montmorillonite) $+\mathrm{SiO}_{2} \rightarrow$ opal + gibbsite, leading to loss of $\mathrm{K}^{+}, \mathrm{Na}^{+}, \mathrm{Ca}^{2+}$ and $\mathrm{H}_{2} \mathrm{SiO}_{4}$. Olivine $((\mathrm{Mg}$, $\left.\mathrm{Fe})_{2} \mathrm{SiO}_{4}\right)$ and pyroxene $\left(\mathrm{Ca}(\mathrm{Mg}, \mathrm{Fe}, \mathrm{Al})[\mathrm{Si}, \mathrm{Al}]_{2} \mathrm{O}_{6}\right)$ are unstable $\mathrm{Fe}$ and $\mathrm{Mg}$ minerals that are highly susceptible to weathering. During weathering and soil formation, especially under the action of carbonic acid, $\mathrm{Ca}^{2+}, \mathrm{Mg}^{2+}$ and $\mathrm{Fe}^{2+}$ ions are first separated to form bicarbonates during decomposition, then dissolved in water and carried away. Under oxidation, the low-valent iron in these minerals is oxidized to high-valent iron, orming hydrous iron oxides. These minerals remain in-situ to form red-, brown-, and hazelcolored soils.

The main mineral component of carbonate rocks is calcium carbonate. Under the long-term action of $\mathrm{CO}_{2}$-rich rainwater, calcium carbonate undergoes chemical dissolution $\left(\mathrm{CaCO}_{3}+\mathrm{H}_{2} \mathrm{O}+\right.$ $\mathrm{CO}_{2} \rightarrow \mathrm{Ca}^{2+}+2 \mathrm{HCO}_{3}{ }^{-}$). Overall, $90 \%$ of $\mathrm{Ca}^{2+}$, $\mathrm{Mg}^{2+}$ and other dissolved substances are lost due to water transportation. The remaining materials that are insoluble in acids, such as quartz, feldspar, clay and Fe and Al oxides, remain on the surface to form soil. Therefore, the time used by the carbonate rock parent materials to form soil is up to 10 times that used by other parent materials $[10,11]$.

Basalt is located in the continental rift system in the Emeishan basalt area. Compared to its parent rock, the soil that basalt forms was rich in Al and $\mathrm{Fe}$ but depleted in $\mathrm{Ca}, \mathrm{Mg}, \mathrm{Na}, \mathrm{K}$ and $\mathrm{Si}$ (Table 1). During soil formation from carbonate parent materials, approximately $96 \%$ of $\mathrm{Ca}$ and $52 \%$ of $\mathrm{Mg}$ were lost, whereas $\mathrm{Fe}, \mathrm{Al}, \mathrm{Si}, \mathrm{K}$ and $\mathrm{Na}$ were enriched by 164, 5.5, 4, 16 and 2.9 times, respectively (Table 2 ).

Mechanisms driving the macroscopic distribution of Fe and Al. The above-mentioned enrichment and depletion characteristics of major elements during soil formation have been clearly verified through their spatial distributions. The deep and top soils above the basalt and limestone parent materials were considerably enriched in $\mathrm{Fe}$ and $\mathrm{Al}$, indicating significant control by soil parent materials over the distributions

Table 1. Chemical compositions of major elements in Emeishan basalt and soil

Таблица 1. Химический состав основных элементов в Эмейшанских базальтах и почвах

\begin{tabular}{|c|c|c|c|c|c|c|c|}
\hline \multirow{2}{*}{ Statistics } & \multicolumn{7}{c|}{$W_{\mathrm{B}} / \%$} \\
\cline { 2 - 9 } & $\mathrm{SiO}_{2}$ & $\mathrm{Al}_{2} \mathrm{O}_{3}$ & $\mathrm{TFe}_{2} \mathrm{O}_{3}$ & $\mathrm{MgO}$ & $\mathrm{CaO}$ & $\mathrm{Na}_{2} \mathrm{O}$ & $\mathrm{K}_{2} \mathrm{O}$ \\
\hline Number of samples & 859 & 859 & 859 & 859 & 859 & 859 & 859 \\
\hline Minimum & 27.83 & 9.4 & 6.48 & 0.32 & 0.09 & 0.06 & 0.09 \\
\hline Maximum & 67.47 & 25.39 & 31.41 & 8.73 & 14.04 & 3.2 & 3.5 \\
\hline Mean & 42.17 & 17.16 & 17.4 & 1.14 & 0.73 & 0.39 & 1.08 \\
\hline Median & 41.6 & 17.56 & 17.97 & 1.01 & 0.52 & 0.29 & 1.04 \\
\hline Standard deviation & 6.43 & 2.28 & 3.26 & 0.6 & 0.94 & 0.35 & 0.36 \\
\hline $\begin{array}{c}\text { Average chemical composition } \\
\text { of the Emeishan basalt }(n=416)^{*}\end{array}$ & 50.03 & 13.89 & 14.06 & 5.17 & 8.45 & 2.84 & 1.33 \\
\hline Soil / Rock & 0.84 & 1.24 & 1.24 & 0.22 & 0.09 & 0.14 & 0.81 \\
\hline
\end{tabular}

Note. ${ }^{*}$ - see reference [8].

Примечание. * - см. источник [8]. 
Table 2. Chemical compositions of major elements in carbonate rocks and soil Таблица 2. Химический состав основных элементов в карбонатных породах и почвах

\begin{tabular}{|c|c|c|c|c|c|c|c|c|}
\hline \multirow{2}{*}{$\begin{array}{l}\text { Sampling } \\
\text { medium }\end{array}$} & \multirow{2}{*}{ Statistics } & \multicolumn{7}{|c|}{$w_{B} / \%$} \\
\hline & & $\mathrm{SiO}_{2}$ & $\mathrm{Al}_{2} \mathrm{O}_{3}$ & $\mathrm{TFe}_{2} \mathrm{O}_{3}$ & $\mathrm{MgO}$ & $\mathrm{CaO}$ & $\mathrm{Na}_{2} \mathrm{O}$ & $\mathrm{K}_{2} \mathrm{O}$ \\
\hline \multirow{6}{*}{ Carbonate } & Number of samples & 34 & 34 & 34 & 34 & 34 & 34 & 34 \\
\hline & Minimum & 9.75 & 1.9 & 0.01 & 0.03 & 0.1 & 0.02 & 0.01 \\
\hline & Maximum & 96.21 & 4.66 & 0.43 & 7.23 & 55.39 & 0.06 & 1.31 \\
\hline & Mean & 16.13 & 2.62 & 0.05 & 0.93 & 48.33 & 0.04 & 0.06 \\
\hline & Median & 10.03 & 2.49 & 0.01 & 0.37 & 52.19 & 0.04 & 0.01 \\
\hline & Standard deviation & 20.34 & 0.48 & 0.1 & 1.43 & 12.89 & 0.01 & 0.23 \\
\hline \multirow{6}{*}{ Soil } & $\begin{array}{l}\text { Number } \\
\text { of samples }\end{array}$ & 495 & 495 & 495 & 495 & 495 & 495 & 495 \\
\hline & Minimum & 30.72 & 5.88 & 1.79 & 0.13 & 0.12 & 0.05 & 0.17 \\
\hline & Maximum & 87.18 & 26.76 & 24.48 & 1.33 & 22.13 & 0.73 & 3.99 \\
\hline & Mean & 64.34 & 14.36 & 7.54 & 0.45 & 1.99 & 0.12 & 1.01 \\
\hline & Median & 63.99 & 14.24 & 6.81 & 0.43 & 0.37 & 0.09 & 0.78 \\
\hline & Standard deviation & 12.68 & 4.3 & 3.82 & 0.2 & 3.9 & 0.09 & 0.7 \\
\hline \multicolumn{2}{|c|}{ Soil / Rock } & 3.99 & 5.47 & 164.3 & 0.48 & 0.04 & 2.87 & 16.01 \\
\hline
\end{tabular}

of Fe and $\mathrm{Al}$ (Figs. 4 and 5). Furthermore, Fe and Al contents in soil increased with elevation (Fig. 6), suggesting that during soil formation, Fe and Al did not substantially migrate from high elevations to the base of mountains. Therefore, the high $\mathrm{Fe}$ and $\mathrm{Al}$ contents in soil were the result of secondary enrichment due to parent material weathering.

The top soil is in direct contact with the atmosphere and biosphere and affected by industrial and agricultural activities. During soil formation, the soluble base cations in the top soil are more likely to be washed away, resulting in lower $\mathrm{pH}$ (5.82) than the deep soil (6.04). Additionally, irrespective of ground cover types (farmlands, forests, grasslands, etc.), the root system of vegetation is mainly concentrated at a shallow depth of tens of centimeters. Moreover, the root and microbial growth activities of crops can produce large quantities of organic acids, adding to the already highest levels of acid rain in China the study area receives. In acidic environments, $\mathrm{Fe}^{2+}$ and $\mathrm{Fe}^{3+}$ are formed during the weathering of $\mathrm{Fe}$ rich ferromagnesian minerals. The migration capacity of $\mathrm{Fe}^{2+}$ is much greater than that of $\mathrm{Fe}^{3+}$, and exchangeable $\mathrm{Al}$ is more likely to enter the soil solution and migrates with water. Together, these factors were suggested as the main mechanism driving the lowering of $\mathrm{TFe}_{2} \mathrm{O}_{3}$ and $\mathrm{Al}_{2} \mathrm{O}_{3}$ concentrations in the top soil, in this case, by $4.6 \%$ and $4.9 \%$, respectively (Fig. 6), compared to the top soil.
Mechanisms driving the macroscopic distributions of $\mathrm{Na}, \mathrm{K}, \mathrm{Ca}, \mathrm{Mg}$ and $\mathrm{Si}$, and $\mathrm{pH}$. Because $\mathrm{Na}, \mathrm{K}, \mathrm{Ca}$ and $\mathrm{Mg}$ are soluble in water, these elements are prone to being washed away and can easily enter the epigenetic environment during weathering and soil formation. The levels of some elements such as $\mathrm{Ca}, \mathrm{Na}$ (Fig. 7), $\mathrm{K}$ and $\mathrm{Mg}$ (not shown) in the top and deep soils increased rapidly with decreasing elevations (Fig. 7), suggesting that these elements mainly entered the surface water system and migrated from high- to low-elevation areas under the action of hydrodynamic forces.

Owing to their different geochemical properties, the above-mentioned elements have significantly different migration and transportation pathways after entering the epigenetic environment. Although $\mathrm{Na}$ and $\mathrm{K}$ have similar geochemical properties, the hydration energy of $\mathrm{Na}$ (indicating how closely the ions are surrounded by water molecules) is greater than that of $\mathrm{K}$. A larger hydration energy means the ion is more difficult to be adsorbed. Therefore, in an epigenetic environment, $\mathrm{Na}$ is more likely to migrate with water, whereas $\mathrm{K}$ is more easily adsorbed by clay minerals or colloids. This is also the main reason $\mathrm{Na}$ was concentrated near the lowest terrain along the Yangtze River (Fig. 8, a), whereas K only occurred in low concentrations in the same area (Fig. 8, b). 

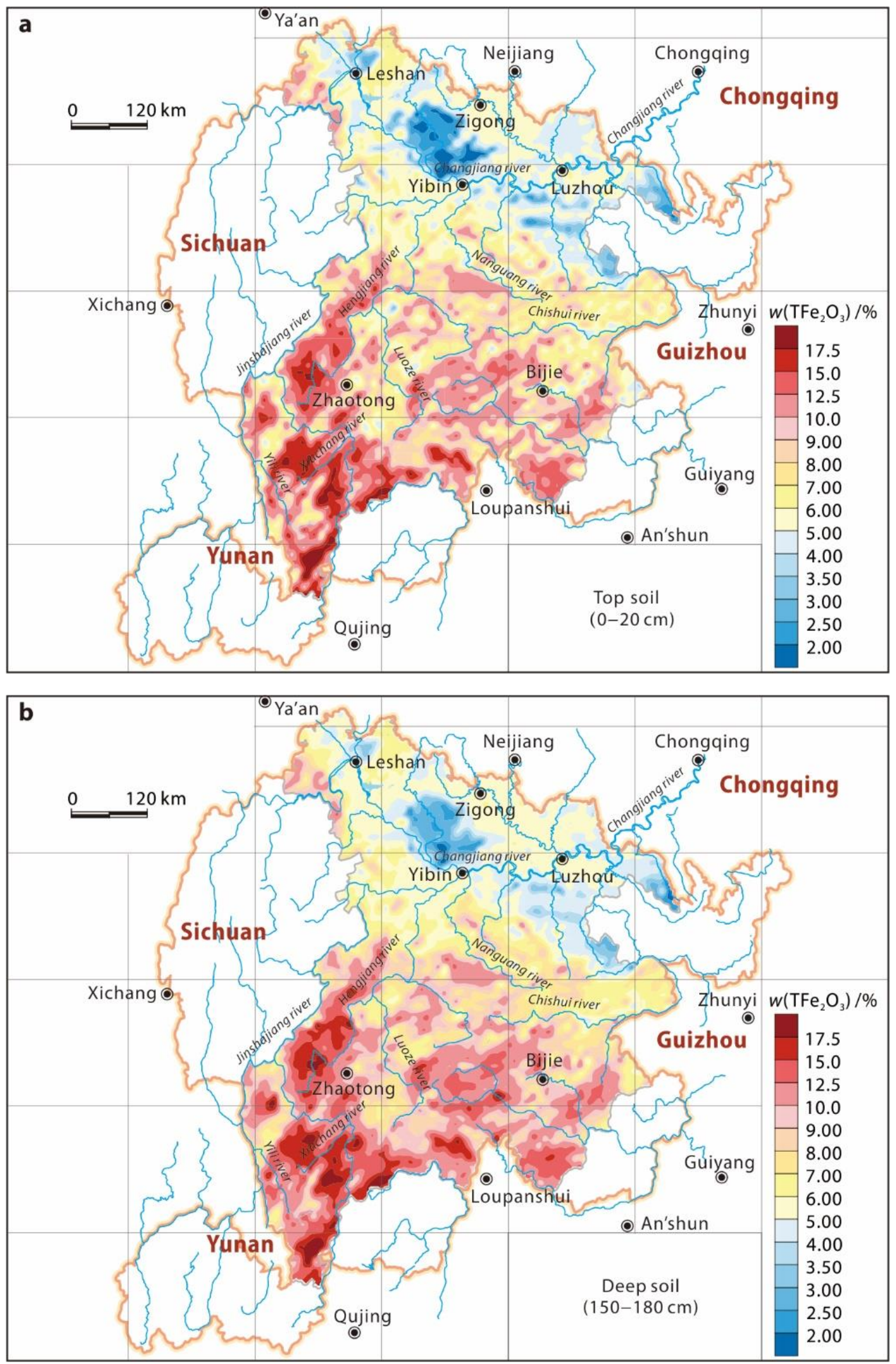

Fig. 4. The $\mathrm{TFe}_{2} \mathrm{O}_{3}$ distribution pattern in top (0-20 cm) (a) and deep $(150-180 \mathrm{~cm})$ (b) soils of the Zhaotong - Bijie - Yibin - Luzhou - Leshan area

Puc. 4. Схема распределения $\mathrm{TFe}_{2} \mathrm{O}_{3}$ в верхних (0-20 см) (a) и глубоких (150-180 см) (b) почвах района Чжаотун - Бицзе - Ибинь - Лучжоу - Лэшань 

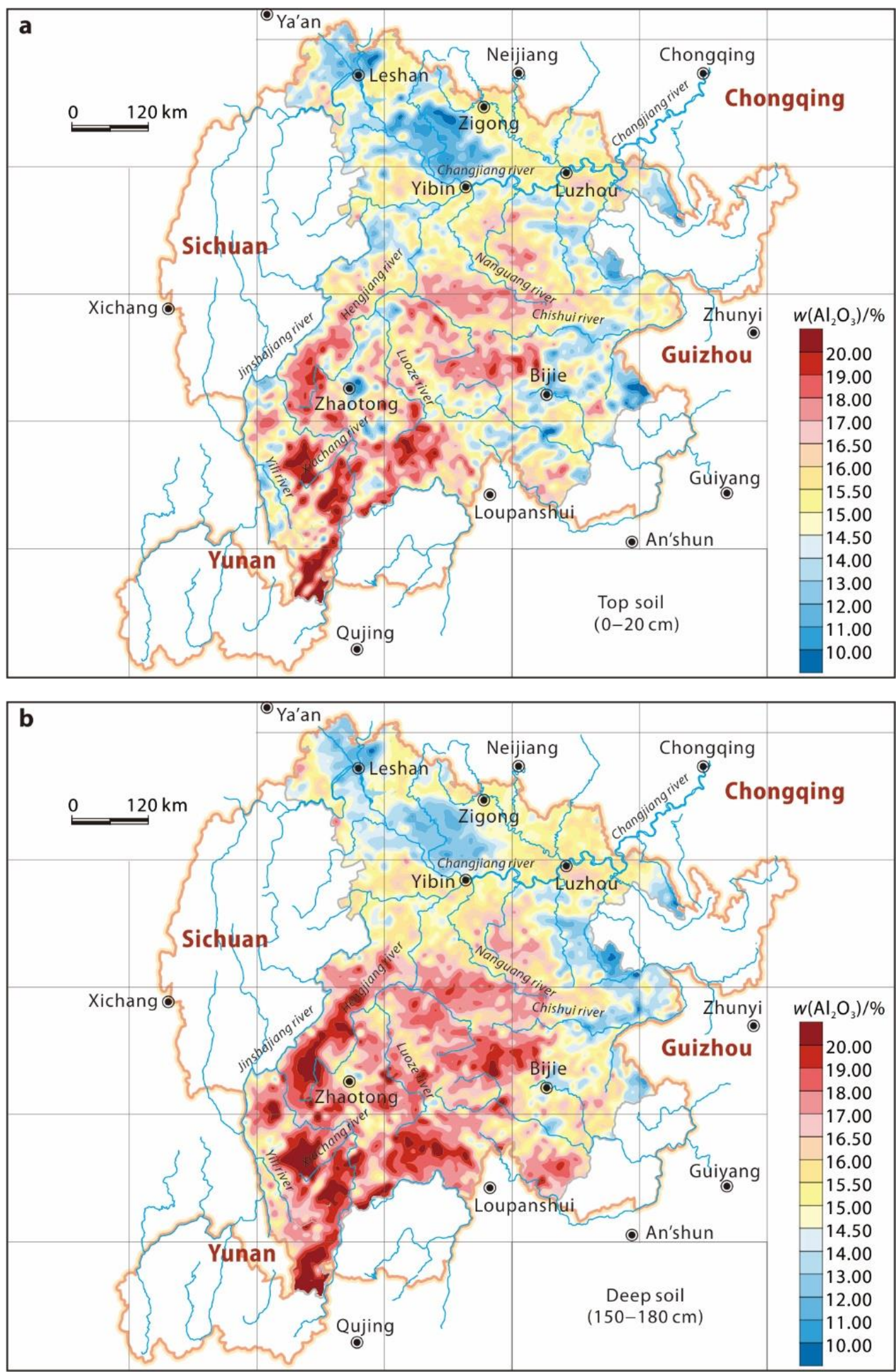

Fig. 5. The $\mathrm{Al}_{2} \mathrm{O}_{3}$ distribution pattern in top $(0-20 \mathrm{~cm})$ (a) and deep $(150-180 \mathrm{~cm})$ (b) soils of the Zhaotong - Bijie - Yibin - Luzhou - Leshan area

Puc. 5. Схема распределения $\mathrm{Al}_{2} \mathrm{O}_{3}$ в верхних (0-20 см) (a) и глубоких (150-180 cм) (b) почвах района Чжаотун - Бицзе - Ибинь - Лучжоу - Лэшань 

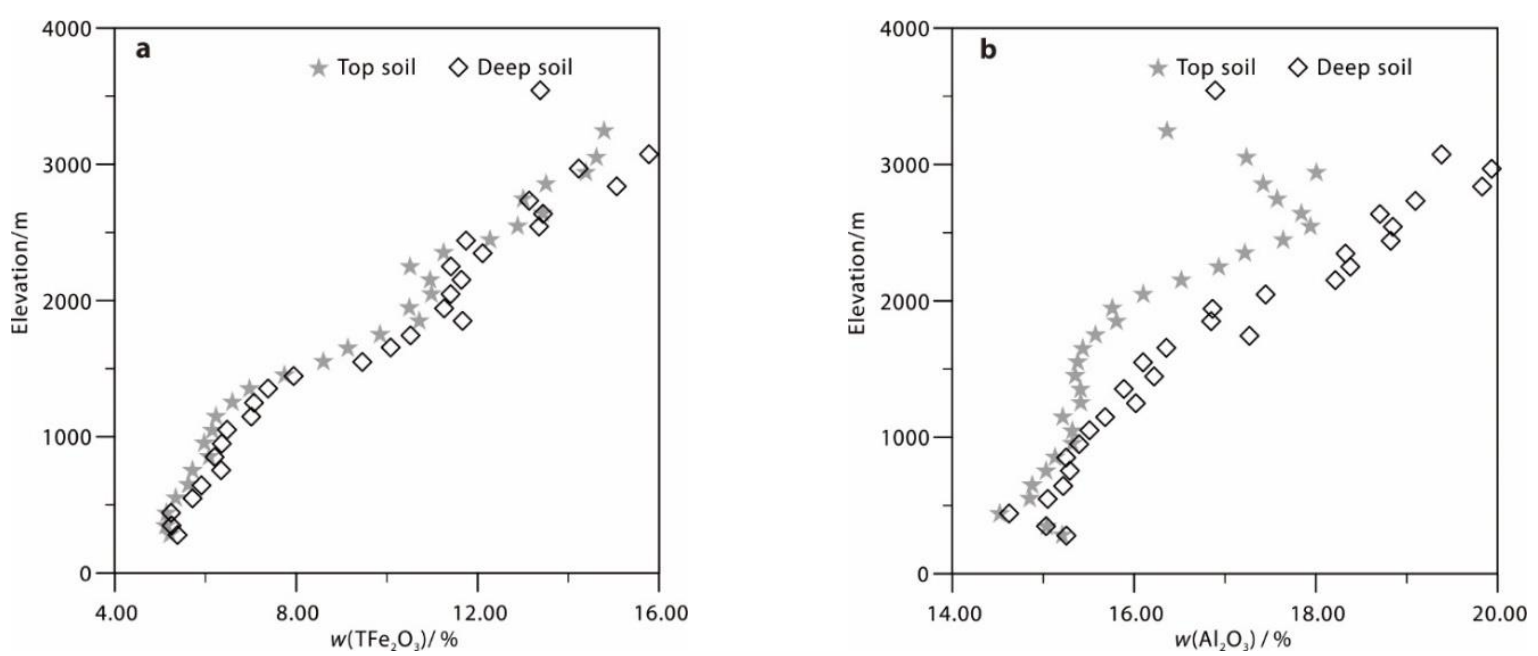

Fig. 6. Plot of $\mathrm{TFe}_{2} \mathrm{O}_{3}$ (a) and $\mathrm{Al}_{2} \mathrm{O}_{3}$ (b) contents in top and deep soils

vs. elevation in the Zhaotong - Bijie - Yibin - Luzhou - Leshan area

Puc. 6. Графиик содержания $\mathrm{TFe}_{2} \mathrm{O}_{3}$ (a) $и \mathrm{Al}_{2} \mathrm{O}_{3}$ (b) в верхних и глубоких почвах в зависимости от высоты в районе Чжаотун - Бицзе - Ибинь - Лучжоу - Лэшань
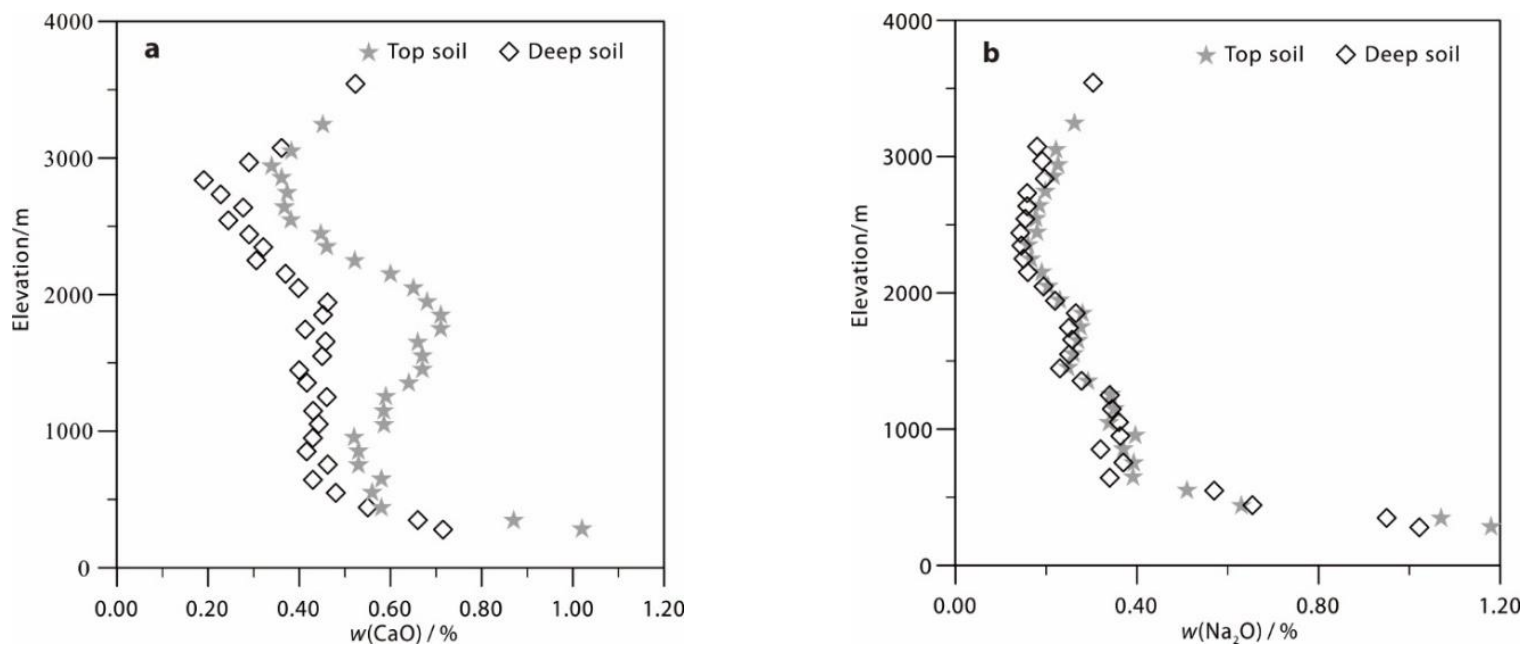

Fig. 7. Plot of $\mathrm{CaO}$ (a) and $\mathrm{Na}_{2} \mathrm{O}$ (b) contents in top and deep soils

vs. elevation in the Zhaotong - Bijie - Yibin - Luzhou - Leshan area

Puc. 7. График содержания $\mathrm{CaO}$ (a) и $\mathrm{Na}_{2} \mathrm{O}$ (b) в верхних и глубоких почвах в зависимости от высоты в районе Чжаотун - Бицзе - Ибинь - Лучжоу - Лэшань

The solubilities of sodium chloride and sodium hydroxide at room temperature were 36 $\mathrm{g} / \mathrm{NaCl}$ and $109 \mathrm{~g} / \mathrm{NaOH}$ in $100 \mathrm{~g}$ water, respectively, while that of calcium bicarbonate was 16.6 $\mathrm{g} / \mathrm{CaHCO}_{3}$ in $100 \mathrm{~g}$ water. These compounds appeared mainly in the forms of $\mathrm{Ca}^{2+}, \mathrm{Cl}^{-}, \mathrm{Na}^{+}$and $\mathrm{OH}^{-}$in natural water. As temperature rises, $\mathrm{Ca}^{2+}$ precipitates before $\mathrm{Na}^{2+}$. All $\mathrm{Na}, \mathrm{K}, \mathrm{Ca}$ and $\mathrm{Mg}$ were lost and enter into the water system during weathering and soil formation. However, due to solubility differences, $\mathrm{Ca}^{2+}$ and $\mathrm{Na}^{+}, \mathrm{Ca}$ and $\mathrm{Mg}$ (not shown) were mainly concentrated in the soils along both sides of the tributary systems, e.g, the Jinsha and Chishui Rivers, by the action of hydrodynamics (Fig. 9, a). Contrarily, Na migrated over a long distance and concentrated within the lowest-lying areas near the Yangtze River (Fig. 8, a). Potassium $\left(\mathrm{K}^{+}\right), \mathrm{Na}^{+}, \mathrm{Ca}^{2+}, \mathrm{Mg}^{2+}$ and other basic ions can all neutralize $\mathrm{H}^{+}$and prevent and regulate the acidification of water bodies and soil. Weathering and soil formation of the widely distributed basalt and carbonate rocks provide sufficient basic ions, such as $\mathrm{K}^{+}, \mathrm{Na}^{+}, \mathrm{Ca}^{2+}$ and $\mathrm{Mg}^{2+}$, to the surface water for buffering acidity and maintaining moderately alkaline conditions in the soils along both sides of the water systems. Figure $9, b$ shows that soils on both sides of the Yangtze River tributaries, including the Jinsha, Hengjiang, Nanguang and Chishui Rivers, were moderately alkaline. These regions overlap precisely with the $\mathrm{Ca}$ rich areas, a clear indication of $\mathrm{H}^{+}$neutralization by $\mathrm{Ca}^{2+}$ and other basic ions. 

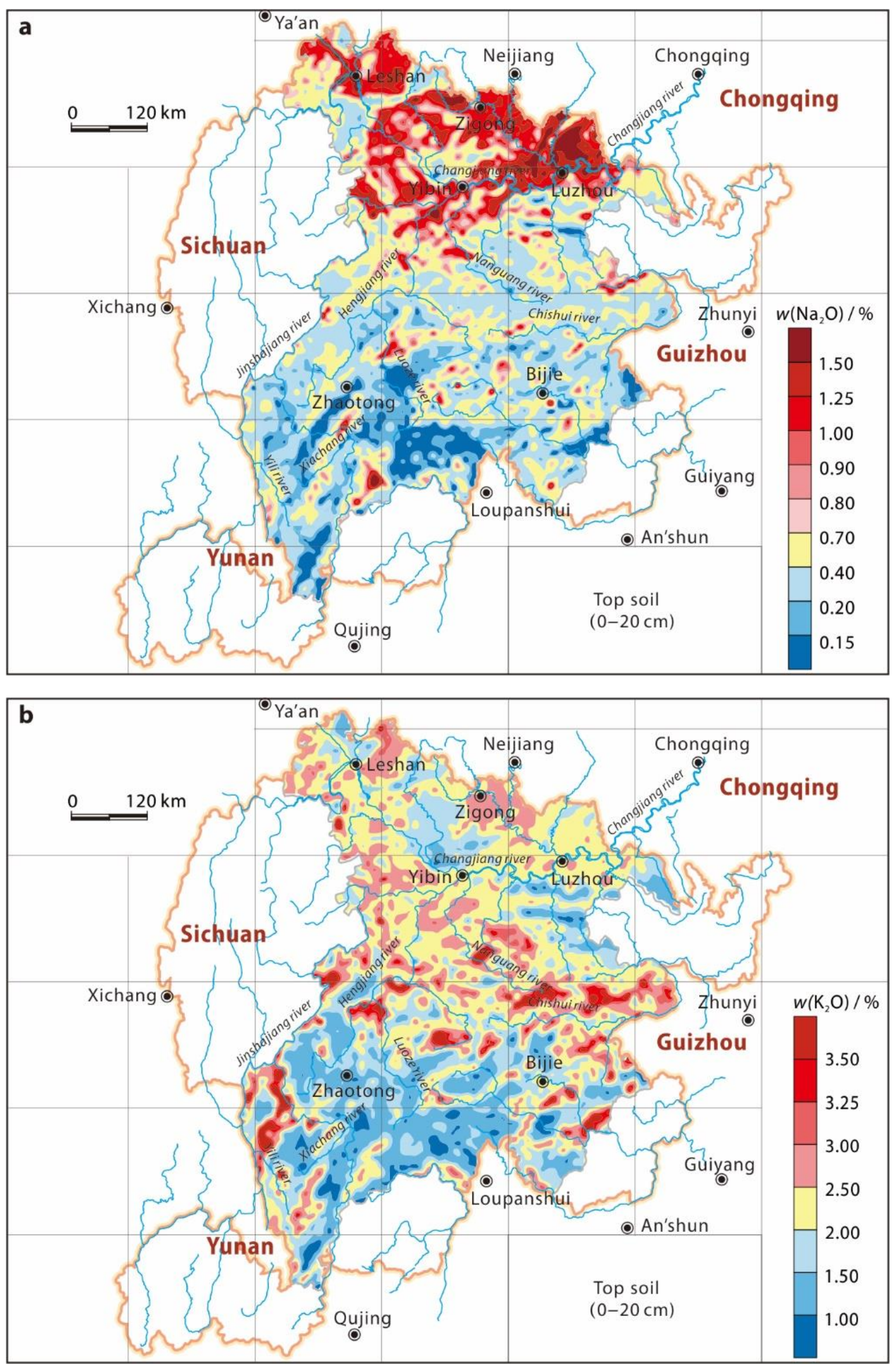

Fig. 8. Distribution pattern of $\mathrm{Na}_{2} \mathrm{O}$ (a) and $\mathrm{K}_{2} \mathrm{O}$ (b) in the top $(0-20 \mathrm{~cm})$ soil of the Zhaotong - Bijie - Yibin - Luzhou - Leshan area

Puc. 8. Схема распределения $\mathrm{Na}_{2} \mathrm{O}$ (a) и $\mathrm{K}_{2} \mathrm{O}$ (b) в верхних (0-20 см) почвах в районе Чжаотун - Бицзе - Ибинь - Лучжоу - Лэшань 

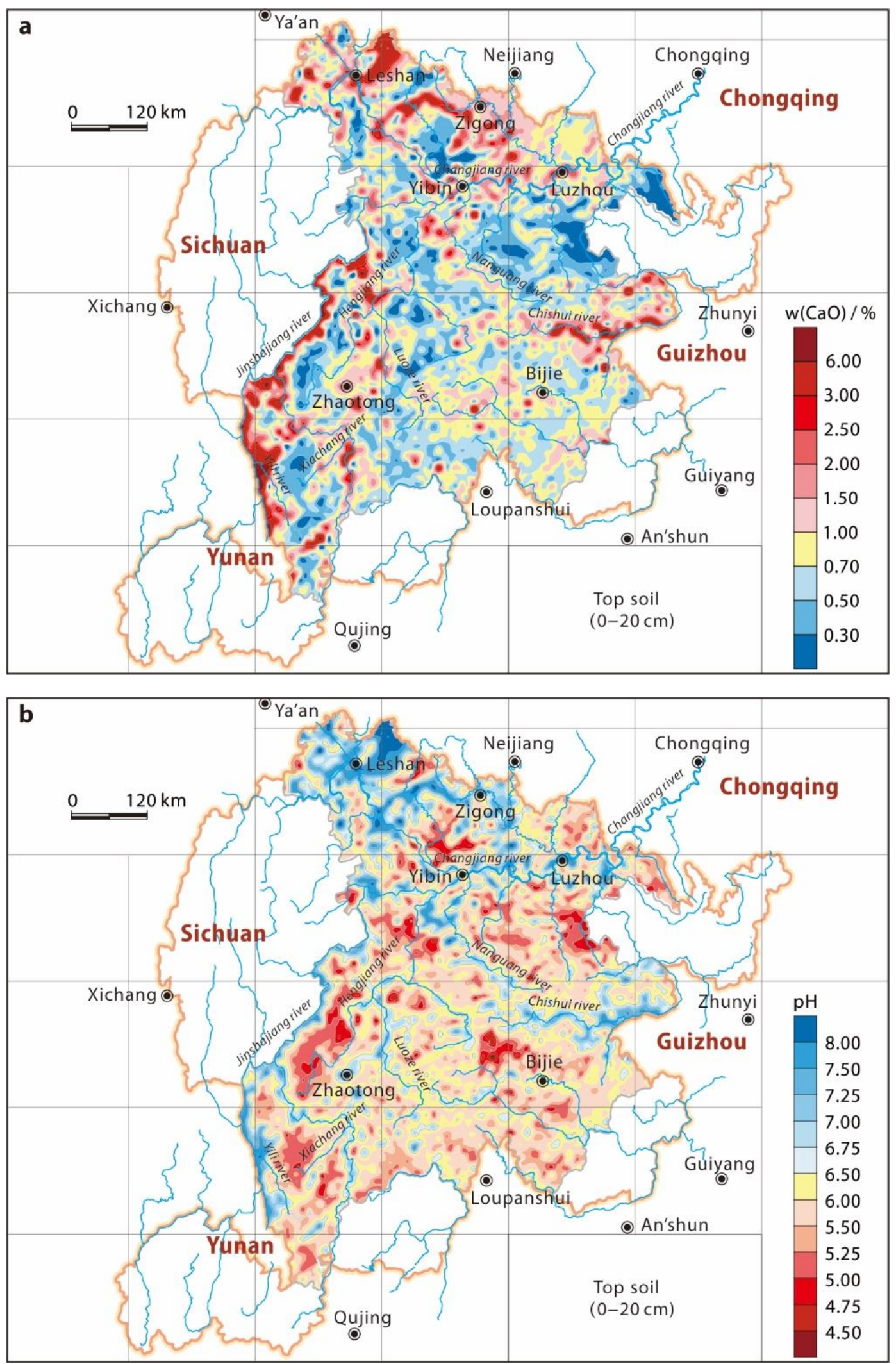

Fig. 9. Distribution pattern of $\mathrm{CaO}$ (a) and pH levels (b) in the top (0-20 cm) soil of the Zhaotong - Bijie - Yibin - Luzhou - Leshan area

Puc. 9. Схема распределения $\mathrm{CaO}$ (a) и уровней рН (b) в верхних (0-20 см) почвах района Чжаотун - Бицзе - Ибинь - Лучжоу - Лэшань 
The insoluble materials formed via weathering and soil formation from carbonate rocks mainly include extremely fine-grained quartz, feldspar and clay $[10,11]$. The study area has abundant annual rainfall, and the terrain exhibits strong undercutting. Silicone content increased rapidly as elevation decreases (Fig. 10), indicating that, under the action of epigenetic hydrodynamics, insoluble minerals, such as quartz and feldspar, migrated along the water system and deposited in the lower-lying terrain in the Leshan - Yibin - Luzhou area (Fig. 11).

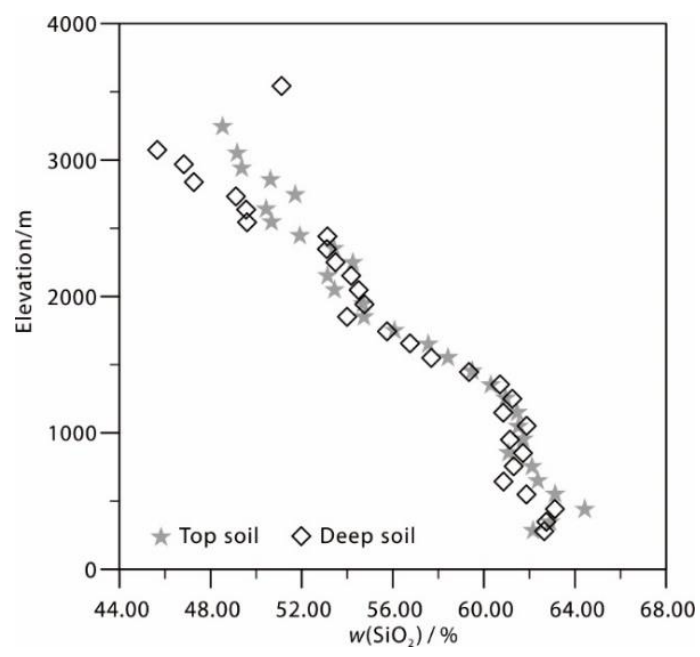

Fig. 10. Plot of $\mathrm{SiO}_{2}$ content in top and deep soils vs. elevation in the Zhaotong - Bijie - Yibin - Luzhou - Leshan area

Puc. 10. График содержания $\mathrm{SiO}_{2}$ в верхних и глубоких почвах в зависимости от глубины в районе Чжаотун - Бицзе - Ибинь - Лучжоу - Лэшань

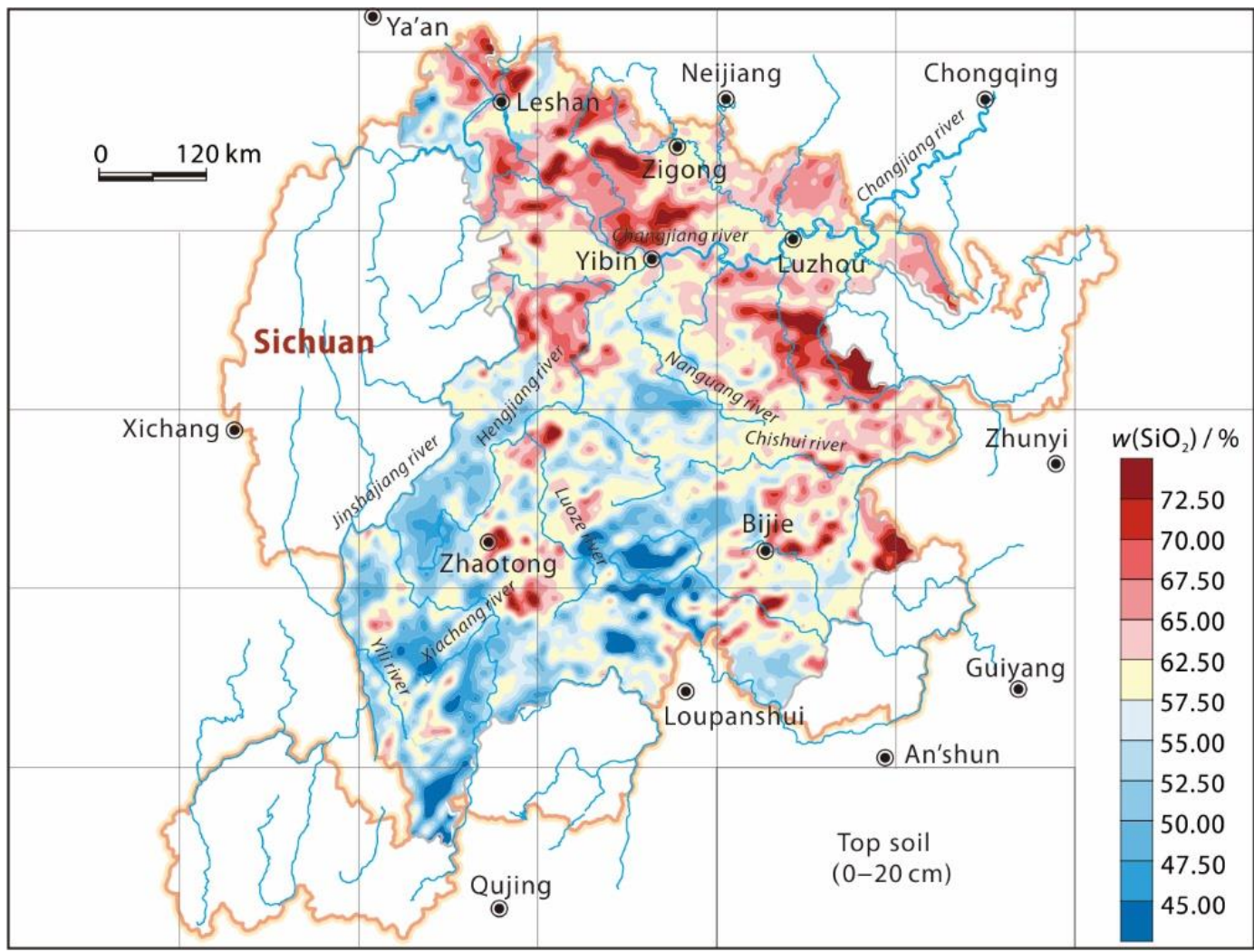

Fig. 11. Distribution pattern of $\mathrm{SiO}_{2}$ in the top $(0-20 \mathrm{~cm})$ soil in the Zhaotong - Bijie - Yibin - Luzhou - Leshan area

Puc. 11. Схема распределения $\mathrm{SiO}_{2}$ в верхних (0-20 см) почвах в районе Чжаотун - Бицзе - Ибинь - Лучжоу - Лэшань 
Mechanism driving the macroscopic distribution of Corg, $N, S$ and $P$. According to the procedures of the National Land Quality Geochemical Survey, we analyzed the levels of 52 elements, $\mathrm{pH}$ and $\mathrm{Corg}^{5}$. Thirty-five of the elements participate in biogeochemical processes and have clear biological effects. They included $\mathrm{Na}, \mathrm{K}, \mathrm{Be}, \mathrm{Mg}, \mathrm{Ca}, \mathrm{V}, \mathrm{Cr}, \mathrm{Mo}, \mathrm{W}, \mathrm{U}, \mathrm{Mn}$, $\mathrm{Fe}, \mathrm{Co}, \mathrm{Ni}, \mathrm{Cu}, \mathrm{Ag}, \mathrm{Zn}, \mathrm{Cd}, \mathrm{Hg}, \mathrm{B}, \mathrm{Al}, \mathrm{Tl}, \mathrm{C}, \mathrm{Si}$, $\mathrm{Sn}, \mathrm{Pb}, \mathrm{N}, \mathrm{P}, \mathrm{As}, \mathrm{Sb}, \mathrm{S}, \mathrm{Se}, \mathrm{F}, \mathrm{Cl}$ and I [12]. In particular, $\mathrm{C}, \mathrm{N}, \mathrm{P}$ and $\mathrm{S}$ were the main elements involved in the biogeochemical cycle.

In the study area, the Corg, N, S and P contents in the top soil were significantly greater than in the deep soil. As elevation increases, the elemental contents in both soils gradually in-

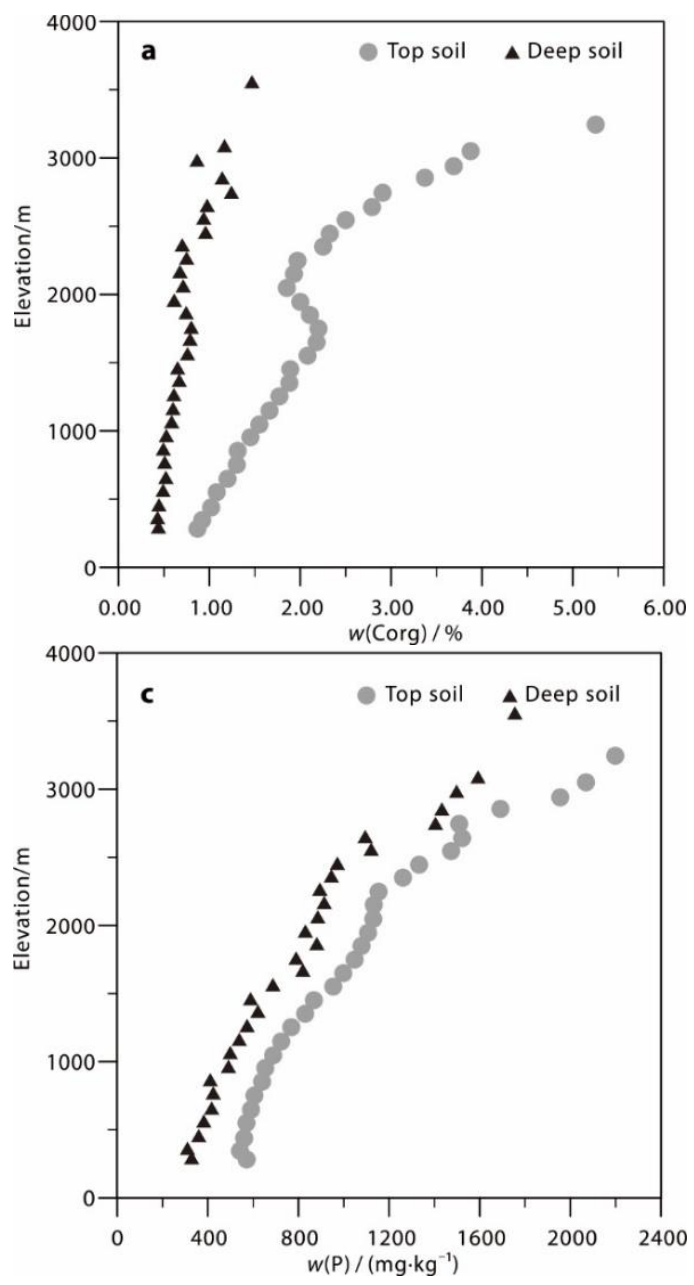

creased. The absolute increase of the four elements in the top soils of the mid- and high-elevation mountainous areas above $2,000 \mathrm{~m}$ were significantly greater than that of the low-elevation areas (Fig. 12). In the major agricultural production region, the top soil was only slightly enriched in all four elements. Organic carbon (Fig. 13), N (Fig. 14), S and $P$ (not shown) were significantly enriched in the top soils of the Zhaotong - Bijie forest and grassland areas above 2,000 m.

Carbohydrates, lipids, proteins and nucleic acids are the four basic substances essential for life; and $\mathrm{C}, \mathrm{O}, \mathrm{H}, \mathrm{N}, \mathrm{P}$ and $\mathrm{S}$ are the major elements required for the synthesis of these basic substances. In the biogeochemical process of plant growth, $\mathrm{C}$ and $\mathrm{N}$ are mainly involved in the

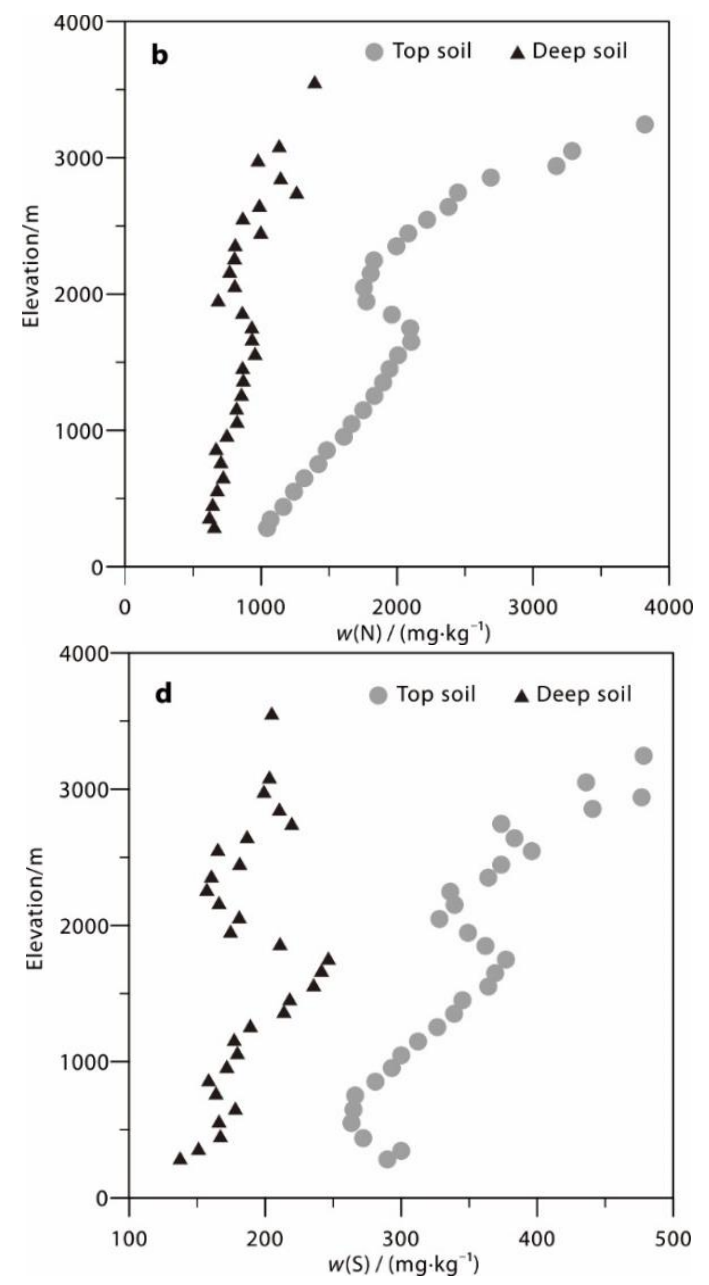

Fig. 12. Plot of $C_{\text {org }}(a), N(b), P(c)$ and $S(d)$ contents in the top and deep soils vs. elevation in the Zhaotong - Bijie - Yibin - Luzhou - Leshan area

Puc. 12. График содержания $C_{\text {org }}(a), N(b), P(c)$ u $S(d)$ в верхних и глубоких почвах в зависимости от глубины в районе Чжаотун - Бицзе - Ибинь - Лучжоу - Лэшань

\footnotetext{
${ }^{5}$ Ministry of Land and Resources of the People's Republic of China. Code for multi-target regional geochemical surveys (1:250000) (DZ/T 0258-2014). Beijing: China Standard Press, 2015. 43 p.
} 

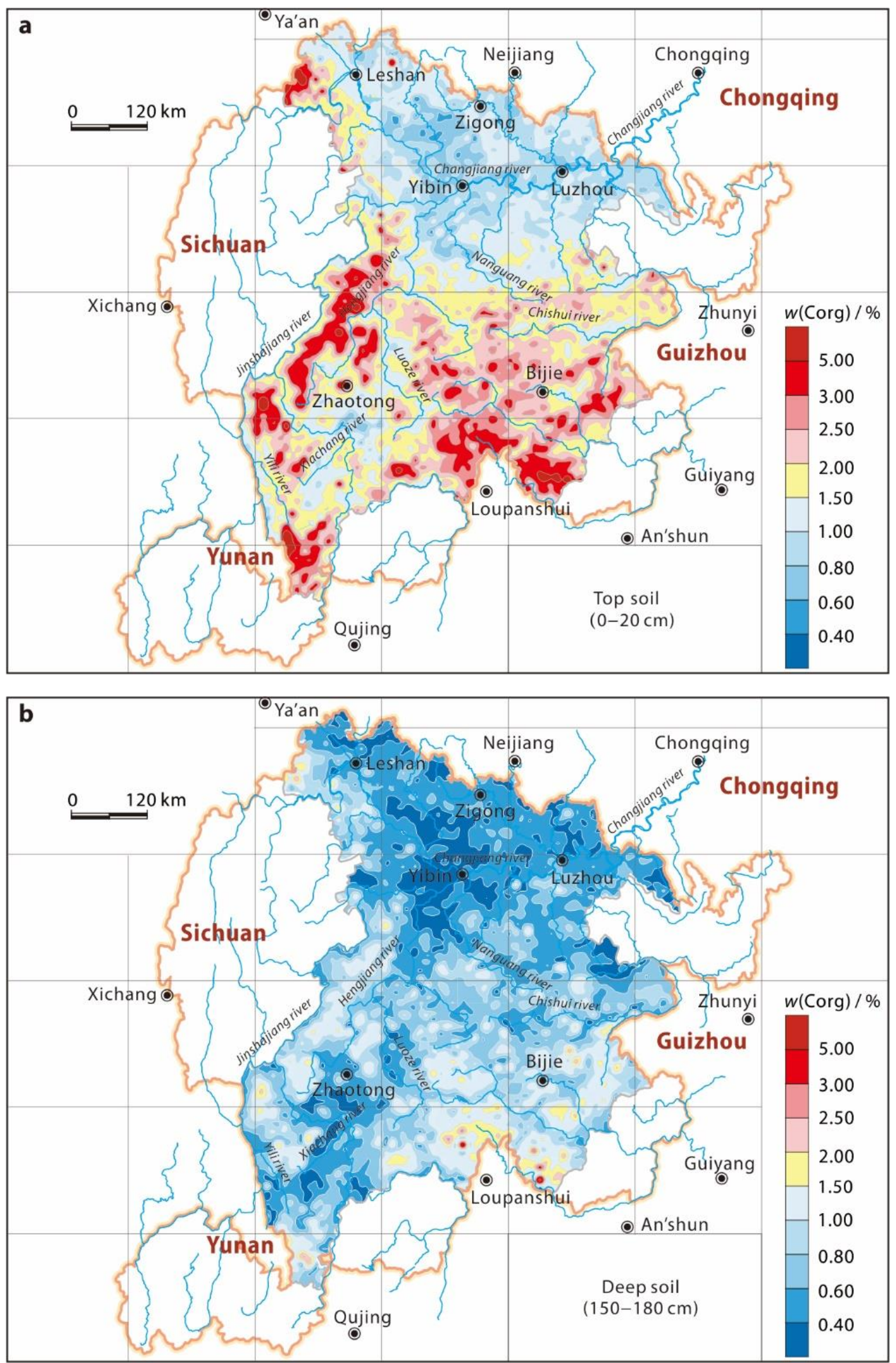

Fig. 13. Distribution pattern of $C_{\text {org }}$ in the top $(0-20 \mathrm{~cm})$ (a) and deep $(150-180 \mathrm{~cm})(\mathrm{b})$ soils of the Zhaotong - Bijie - Yibin - Luzhou - Leshan area

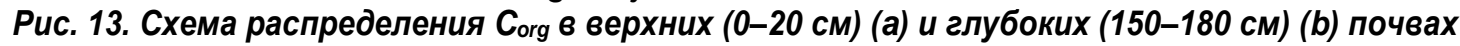
в районе Чжаотун - Бицзе - Ибинь - Лучжоу - Лэшань 

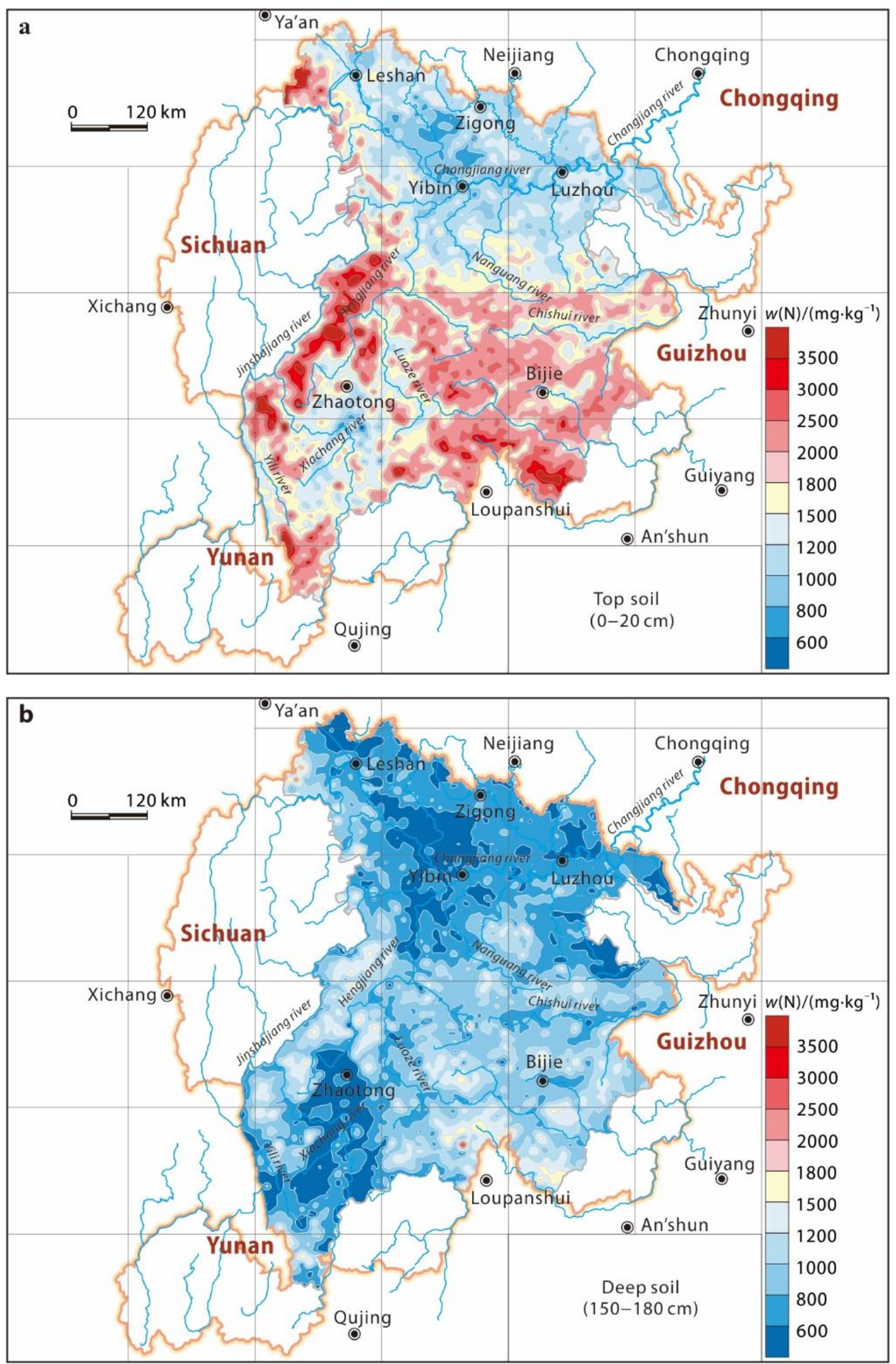

Fig. 14. Distribution pattern of $N$ in the top $(0-20 \mathrm{~cm})$ (a) and deep $(150-180 \mathrm{~cm})(\mathrm{b})$ soils of the Zhaotong - Bijie - Yibin - Luzhou - Leshan area

Puc. 14. Сема распределения $N$ в верхних (0-20 cм) (a) и глубоких (150-180 cм) (b) почвах в районе Чжаотун - Бицзе - Ибинь - Лучжоу - Лэшань 
synthesis of carbohydrates and lipids, while $S$ and $P$ are needed to synthesize proteins and nucleic acids. Thus, the $\mathrm{C} / \mathrm{N}$ ratio remains fixed in the plant body ( $\mathrm{C}: \mathrm{N}=15)$. The functions of $\mathrm{C}, \mathrm{N}$, $S$ and $P$ render them to follow nearly identical evolutionary patterns in plant production. Although a large amount of chemical fertilizers (mainly nitrogen fertilizers) have been used in agricultural production in China in the last 30 years [13], analyses clearly demonstrate that $\mathrm{C}_{\text {org }}, \mathrm{N}$, $S$ and $P$ enrichment in the top soils of the Zhaotong - Bijie - Yibin - Luzhou - Leshan area is driven by the biogeochemical processes of forest and grassland ecosystems. Despite minor cumulation of $\mathrm{C}_{\text {org }}, \mathrm{N}, \mathrm{S}$ and $\mathrm{P}$ in the top soils of the Yibin - Luzhou - Leshan agricultural area, the accumulation effects attributed to intensive agricultural activities are significantly smaller than those naturally occurring in forest and grassland ecosystems.

\section{Mechanism driving the macroscopic distribution of $\mathrm{Cl}, \mathrm{Br}$ and I}

The $\mathrm{Cl}, \mathrm{Br}$ and I concentrations in the top soils of the study area were $23.3 \%, 51.1 \%$ and $23.5 \%$, respectively, higher than that in the deep soil; however, the $\mathrm{F}$ content was slightly lower in the top soil $(-2.8 \%)$.

The combined analyses of elevation variations and the $\mathrm{F}, \mathrm{Cl}, \mathrm{Br}$ and I contents in the top and deep soils showed that the F content was basically the same at different elevations, but highest at around 1,500 $\mathrm{m}$ above sea level, indicating that $F$ does not change significantly with elevation in an epigenetic environment (Fig. 15, a). Hence, $F$ concentrations showed consistent spatial distribution patterns in both soils (not shown). Moreover, $\mathrm{F}$ rich areas coincided with the carbonate rich areas. Fluorine distribution is mainly controlled by the carbonate parent materials.

Fluorine, $\mathrm{Cl}, \mathrm{Br}$ and I are halogen elements known by their high chemical reactivity. Chlorine often exists as a monovalent anion $\left(\mathrm{Cl}^{-}\right)$as well as $\mathrm{Cl}(\mathrm{V})$ and $\mathrm{Cl}(\mathrm{VII})$ species in the natural environment. Chlorine released during soil formation is mostly in water-soluble form and eventually migrates into the ocean along with water. Therefore, the $\mathrm{Cl}$ contents in marine sediments or sedimentary rocks are relatively high. We found that $\mathrm{Cl}$, $\mathrm{Br}$ and I levels in the top soil were all significantly higher than in the deep soil. However, chlorine content increased with decreasing elevation (Fig. 15, b), indicating $\mathrm{Cl}$ migration from medium and high elevations to the low hilly areas, whereas $\mathrm{Br}$ and I contents increased with increasing elevation (Fig. 15, c, d).

The $\mathrm{Cl}$ distribution pattern showed that it had significantly enriched the top soils on both sides of the Yangtze River and in the Pd-Zn-Ag deposit in the Leshan - Yibin - Luzhou area (Fig. 16), consistent with extensive distribution of $\mathrm{Cl}$ rich carbonate rocks in the study area. Chlorine released during weathering and soil formation is concentrated along both sides of the Yangtze River, due to the action of hydrodynamic forces, and forms an ionic compound with $\mathrm{Na}$. This is the primary reason we detected abnormally high levels of $\mathrm{Cl}$ and $\mathrm{Na}$ (Fig. 8, a) on both sides of the Yangtze River.

The $\mathrm{Cl}$ anomaly region between the Luoze and Xiaochang Rivers is near a Pd-Zn-Ag mine cluster (Fig. 3). A study on the mineral composition of the deposits found that chlorargyrite exists in the oxidation zone of the large $\mathrm{Pb}-\mathrm{Zn}-\mathrm{Ag}$ deposits in Yinchangpo, Guizhou Province [14]. The high $\mathrm{Cl}$ content in chlorargyrite $(24.7 \%)$ suggested that natural weathering and mining activities might have driven the high degree of $\mathrm{Cl}$ enrichment in the deposits.

Due to the impact of the parent materials, the deep soil above the basalt and carbonate source rocks were generally enriched in $\mathrm{Br}$ and I (Figs. 17, $b$ and 18, b). In the top soil, especially in mid-alpine forests with basalt parent materials, $\mathrm{Br}$ and I exhibited distinct cumulative distribution patterns (Figs. 17, a and 18, a).

In the natural environment, $\mathrm{Br}$ and I contents in the soil are usually much higher than in the parent rocks. According to classical geochemical theories, soil $\mathrm{Br}$ and I are believed to mainly come from the atmosphere [15], while atmospheric $\mathrm{Br}$ and I originate from ocean evaporation [16]. We found the soil contents of both elements gradually increased with increasing elevation, especially above 2,000 m, indicating high mountain blockage and abundant rainfall are the main reasons for the high $\mathrm{Br}$ and I soil contents. Bromine and I in the natural environment mainly exist as compounds. Alpine terrain and precipitation scouring can enable iodine compounds to enter water 

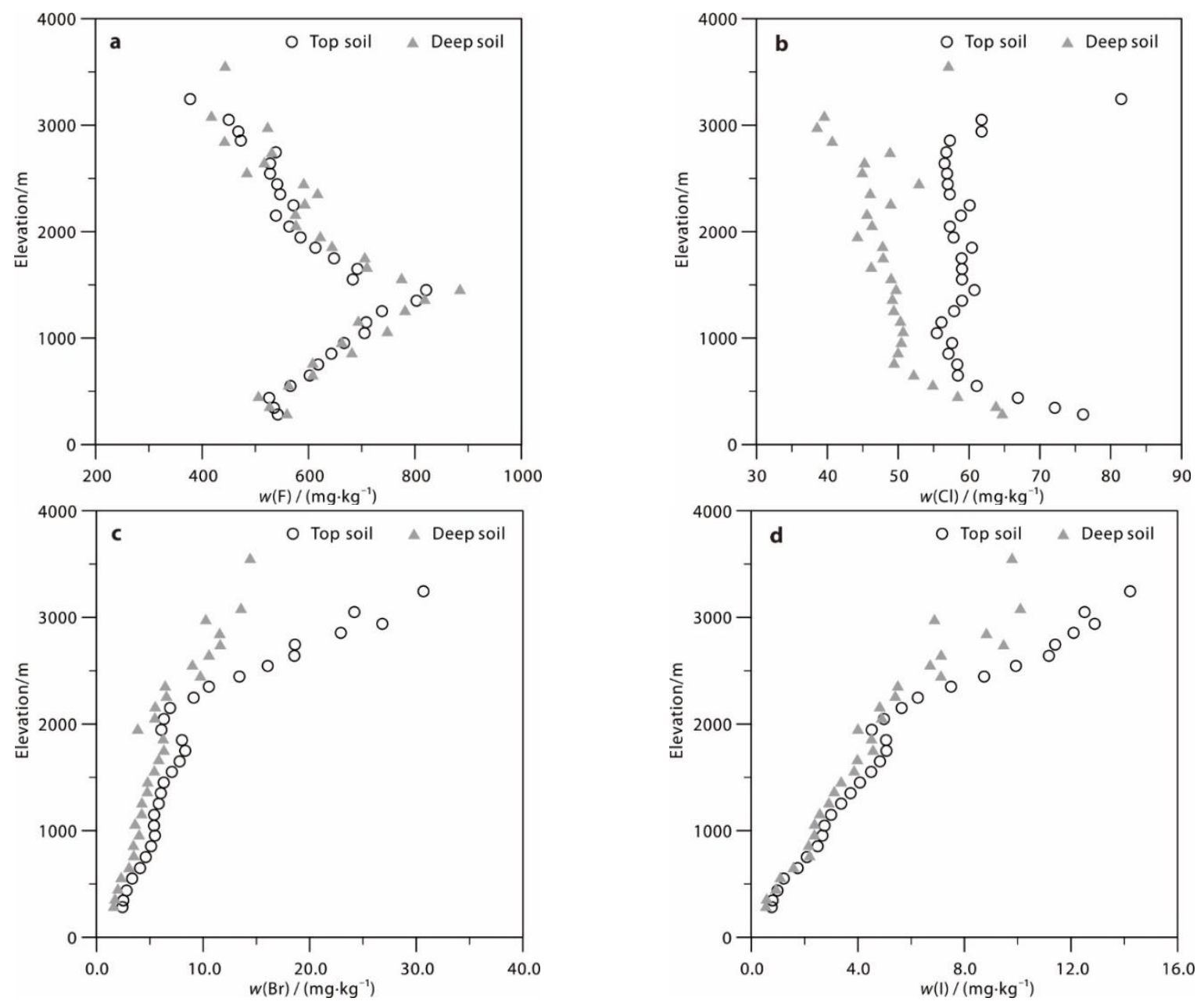

Fig. 15. Plots of $F(a), C l(b), B r(c)$ and I (d) contents in the top and deep soils vs. elevation in the Zhaotong - Bijie - Yibin - Luzhou - Leshan area

Puc. 15. График содержания $\mathrm{F}$ (a), $\mathrm{Cl}$ (b), $\mathrm{Br}$ (c) и I (d) в верхних и нижних почвах в зависимости от глубины в районе Чжаотун - Бицзе - Ибинь - Лучжоу - Лэшань

systems and flow into the ocean. However, the increasing $\mathrm{Br}$ and I contents in the top soil of the Zhaotong - Bijie alpine valley and low $\mathrm{Br}$ and I contents in the soils along the Yangtze River (Fig. 15, c,d), clearly indicated that $\mathrm{Br}$ and I do not exist as water-soluble compounds in soil.

A literature review suggests that sediments rich in organic matter are strongly enriched with iodine; such relationship can be used to determine iodine-holding ability of soils [17]. Indeed, we found positive linear correlation between $\mathrm{C}_{\text {org }}$ and $\mathrm{Br}\left(R^{2}=0.92\right)$ or I $\left(R^{2}=0.88\right)$ in the top soil of the study area, confirming $\mathrm{Br}$ and I enrichments via strong adsorption (Fig. 19). The $\mathrm{C}_{\text {org }}$ contents in mid- and high-elevation alpine forests and grasslands (Fig. 13, a) closely aligned spatially with $\mathrm{Br}$ and I enrichments, thus further suggested that $\mathrm{Br}$ and I mainly occur in their adsorbed form. lodine is restricted to the medium and high elevation areas due to soil organic matter adsorption, making it difficult to enter the piedmont basin. This is also the main reason for the local iodine deficiency in the piedmont basin [18].

\section{Mechanisms driving the macroscopic distribution of heavy metals}

Heavy metals are metal elements with a density of $4.5 \mathrm{~g} / \mathrm{cm}^{3}$ or more. Of the 60 naturally occurring metal elements with atomic numbers from $23(\mathrm{~V})$ to $92(\mathrm{U})$, fifty-four have a density greater than $4.5 \mathrm{~g} / \mathrm{cm}^{3}$. The following 10 metals are classified as heavy metals in industrial applications: $\mathrm{Cu}, \mathrm{Pb}, \mathrm{Zn}, \mathrm{Sn}, \mathrm{Ni}, \mathrm{Co}, \mathrm{Sb}, \mathrm{Hg}, \mathrm{Cd}$ and $\mathrm{Bi}$. Because arsenic has a toxicity similar to that of heavy metals and a density of $5.73 \mathrm{~g} / \mathrm{cm}^{3}$, it is also included as a heavy metal when it occurs in the environment. According to the characteristics of the parent materials in the study area, we selected $\mathrm{Pb}, \mathrm{Zn}, \mathrm{Cd}, \mathrm{Ag}, \mathrm{Cu}, \mathrm{Ni}, \mathrm{Co}$, Ti and $\mathrm{V}$ for our investigation and discussion. 


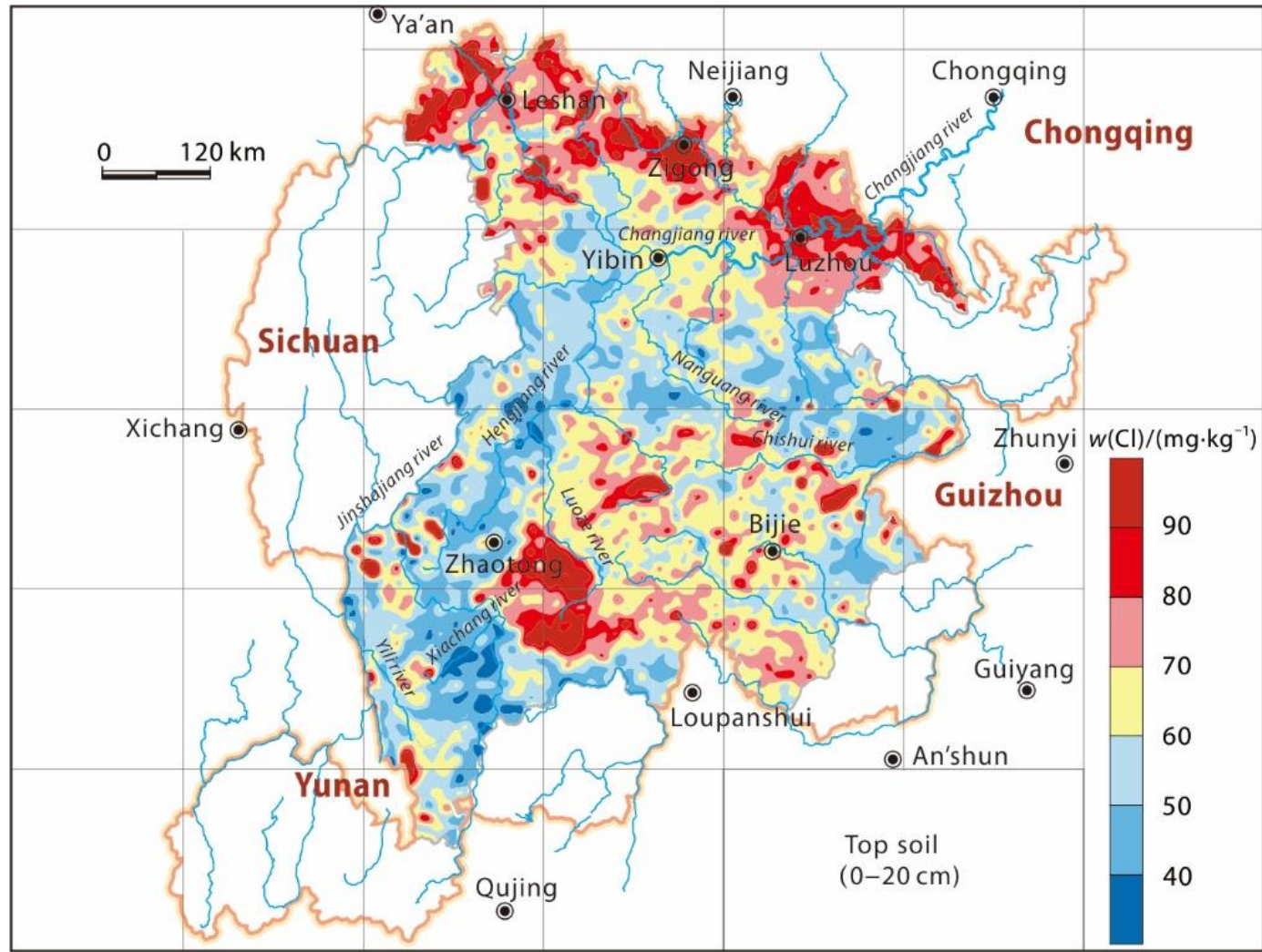

Fig. 16. Chlorine distribution pattern in the top $(0-20 \mathrm{~cm})$ soil of the Zhaotong - Bijie - Yibin - Luzhou - Leshan area

Puc. 16. Схема распределения $\mathrm{Cl}$ в верхних (0-20 см) почвах в районе Чжаотун - Бицзе - Ибинь - Лучжоу - Лэшань

Lead, $\mathrm{Zn}, \mathrm{Cd}$ and $\mathrm{Ag}$. The study area is rich in $\mathrm{Pb}, \mathrm{Zn}$ and $\mathrm{Ag}$ resources. Currently, more than $400 \mathrm{~Pb}-\mathrm{Zn}$ deposits have been discovered, including 5 large and 14 medium-size deposits. There are 14 silver deposits (including one large and three medium-size deposits). Lead, $\mathrm{Zn}$ and Ag deposits are mainly distributed in the Yiliang Hezhang, Huize - Weining and Butuo - Qiaojia mine-cluster areas. Presently, there are more than $120 \mathrm{~Pb}, \mathrm{Zn}$ and $\mathrm{Ag}$ mines, among which 42 are in operation and the rest suspended or closed.

The distributions of $\mathrm{Pb}, \mathrm{Zn}, \mathrm{Ag}$ and $\mathrm{Cd}$ showed that the concentration centers of $\mathrm{Pb}$ (Fig. 20), Zn (Fig. 21), Ag (Fig. 22) and Cd (Fig. 23) in both top and deep soils were strictly controlled by the distributions of $\mathrm{Pb}, \mathrm{Zn}$ and $\mathrm{Ag}$ deposits in the $\mathrm{Pb}-\mathrm{Zn}-\mathrm{Ag}$ mine clusters. Comparison of $\mathrm{Pb}, \mathrm{Zn}$, $\mathrm{Ag}$ and $\mathrm{Cd}$ levels in both soils revealed clear $\mathrm{cu}$ mulative distribution patterns for all elements regardless of their absolute contents. Additionally, regional $\mathrm{Pb}, \mathrm{Zn}, \mathrm{Ag}$ and $\mathrm{Cd}$ peaks occurred in the top soils of the Weining - Hezhang area in Guizhou Province.
Our analyses showed that the cumulation patterns of $\mathrm{Pb}, \mathrm{Zn}, \mathrm{Ag}$ and $\mathrm{Cd}$ in the top soils changed with elevation. Lead, $\mathrm{Zn}$ and $\mathrm{Cd}$ contents peaked at the same elevation as the $\mathrm{Pb}, \mathrm{Zn}$ and $\mathrm{Ag}$ deposits (Fig. 24, $a-C$ ), with decreasing $\mathrm{Ag}$ content as elevation declines (Fig. 24, d). Compared to deep soil, concentrations of $\mathrm{Pb}, \mathrm{Zn}$, $\mathrm{Ag}$ and $\mathrm{Cd}$ in the top soil were higher by $29.8 \%$, $6.8 \%, 18.9 \%$ and $169 \%$, respectively. The difference was more than three orders of magnitude. For $\mathrm{Cd}$, its contents in the top soil were $142 \%, 235 \%$ and $102 \%$ higher than in the deep soil at elevations below $1,800 \mathrm{~m}, 1,800-2,700 \mathrm{~m}$ and above $2,700 \mathrm{~m}$, respectively. For $\mathrm{Zn}$, meanwhile, $2,400 \mathrm{~m}$ was the point of division: at below $2,400 \mathrm{~m}$, the $\mathrm{Zn}$ content in the top soil was 6$18 \%$ higher than in the deep soil, and the difference grew as elevation decreases. At above $2,400 \mathrm{~m}$, the differences were further reduced and even became negative at above $2,800 \mathrm{~m}$. The changes in $\mathrm{Pb}$ and $\mathrm{Ag}$ concentrations in the top soil, however, were significantly different from those for $\mathrm{Zn}$ and $\mathrm{Cd}$. As elevation decreases, $\mathrm{Pb}$ and $\mathrm{Ag}$ contents in the top soil became increasingly similar to that in the deep soil. 

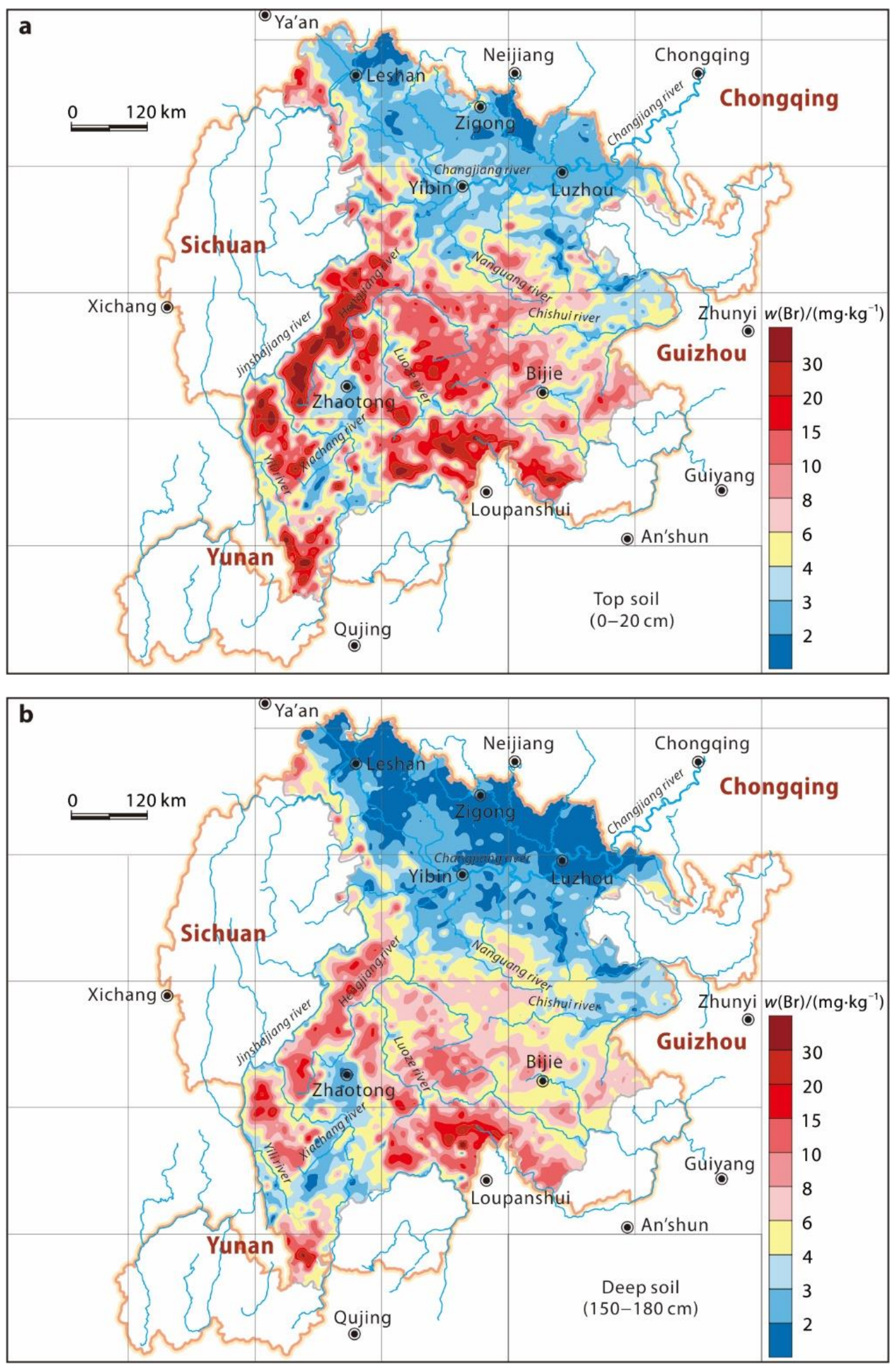

Fig. 17. Bromine distribution pattern in the top $(0-20 \mathrm{~cm})(\mathrm{a})$ and deep $(150-180 \mathrm{~cm})(\mathrm{b})$ soils of the Zhaotong - Bijie - Yibin - Luzhou - Leshan area

Puc. 17. Схема распределения $\mathrm{Br}$ в верхних (0-20 см) (a) и глубоких (150-180 cм) (b) почвах в районе Чжаотун - Бицзе - Ибинь - Лучжоу - Лэшань 

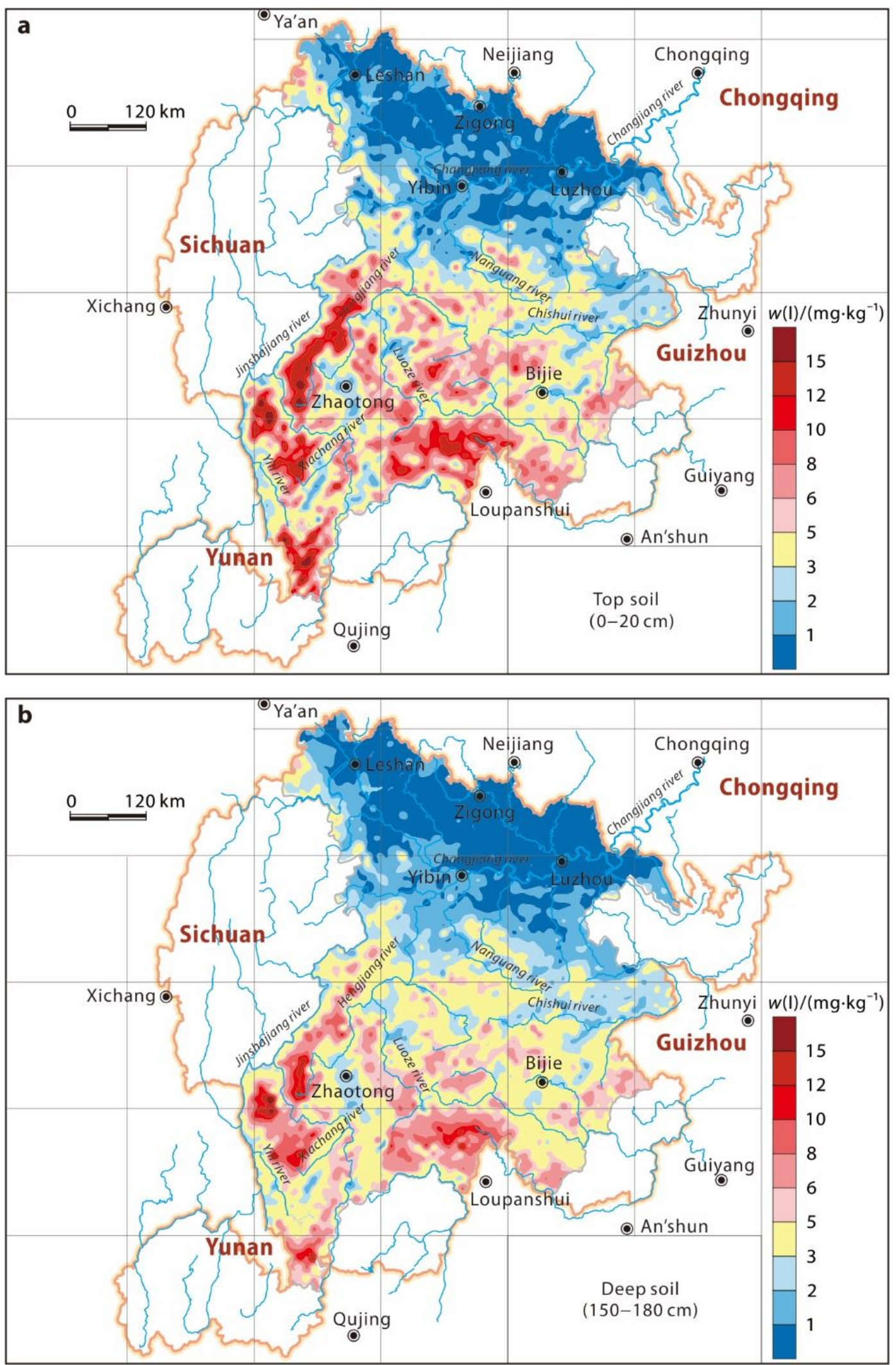

Fig. 18. lodine distribution pattern in the top $(0-20 \mathrm{~cm})$ (a) and deep $(150-180 \mathrm{~cm})(\mathrm{b})$ soils of the Zhaotong - Bijie - Yibin - Luzhou - Leshan area

Puc. 18. Схема распределения I в верхних (0-20 см) (a) и елубоких (150-180 см) (b) почвах в районе Чжаотун - Бицзе - Ибинь - Лучжоу - Лэшань 

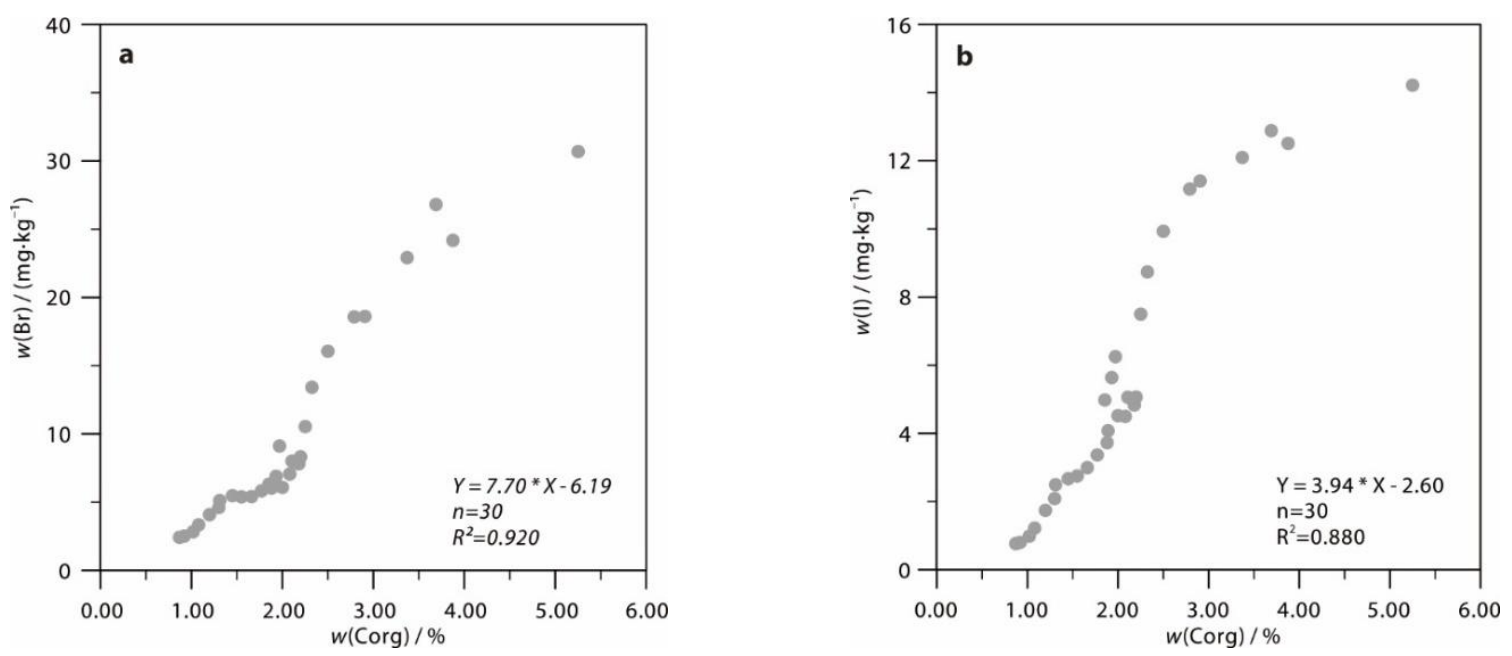

Fig. 19. Correlation between $C_{o r g}$ and $\mathrm{Br}(\mathrm{a})$ or I (b) in the top soil of the Zhaotong - Bijie - Yibin - Quzhou - Leshan area

Puc. 19. Корреляция между $\mathrm{C}_{\text {org }}$ u $\mathrm{Br}$ (a) или I (b) в верхних почвах в районе Чжаотун - Бицзе - Ибинь - Лучжоу - Лэшань

In certain geographical areas, the epigenetic geochemical behavior of elements are mainly depended on their geochemical properties and organic matters, $\mathrm{pH}$ and clay minerals in the top soil. A partial analysis of correlations between $\mathrm{Pd}$, $\mathrm{Zn}, \mathrm{Ag}$ or Cd levels in soils and organic matter or $\mathrm{pH}$ indicated that, the main driver of the geochemical behavior of $\mathrm{Ag}$ and $\mathrm{Pb}$ in an epigenetic environment is organic carbon, while that for $\mathrm{Zn}$ and $\mathrm{Cd}$ is $\mathrm{pH}$ (Table 3). Because $\mathrm{Ag}$ can be strongly adsorbed and fixed by organic matter in epigenetic environments, while $\mathrm{Zn}$ has relatively high solubility in acidic environments, Ag enrichment (Figs. 22, $a$ and 24, d) and Zn depletion (Figs. 21, $a$ and 24, b) were noted in the top soils of alpine meadows and forests.

The magnitude of increasing $\mathrm{Pb}$ and $\mathrm{Cd}$ contents in the top and deep soils at the elevation of the deposits was significantly larger than that in other areas (Fig. 24, a, C). Also, we observed Cd, $\mathrm{Pb}, \mathrm{Zn}$ and $\mathrm{Ag}$ pollution in some regions. It suggests extreme levels of human disturbance, including mining and metal extraction, at the elevation of the deposits. A detailed literature review suggested that the Hezhang - Weining region was once (over 300 years ago) a center for indigenous zinc smelting activities, in addition to the large-, medium-, and small-size $\mathrm{Pb}$ and $\mathrm{Zn}$ mines such as Tianqiao (Zhugongtang), Wuliping, Shaojiwan, Yadu and Zhushachang mines that are currently in operation or closed. The slag formed during mining has been spread throughout the region $[19,20]$ and is the main source of
$\mathrm{Cd}, \mathrm{Pb}, \mathrm{Zn}$ and $\mathrm{Ag}$ pollution (Fig. 25). In a survey of $\mathrm{Cd}$ contents in corn in the above-mentioned areas found that $12.1 \%$ of the investigated corn had $\mathrm{Pb}$ and $\mathrm{Cd}$ contents higher than the allowable amounts [21]. Such finding is rare in corngrowing areas nationwide.

Copper, Ni, Co, Ti and V. The Emeishan LIP is generally considered to be the product of a mantle-plume event $[22,23]$ and characterized by high $\mathrm{Cu}, \mathrm{Ni}, \mathrm{Co}, \mathrm{Cr}, \mathrm{Ti}$ and $\mathrm{V}$ contents. In the southwestern part of the study region, areas with high $\mathrm{Cu}, \mathrm{Ni}, \mathrm{Co}, \mathrm{Cr}$, Ti and $\mathrm{V}$ contents in the top and deep soils overlap with the Emeishan basalt area, and the same holds true for the carbonate area in the southeastern part of the study region. This indicates that the spatial distributions of $\mathrm{Cu}$, $\mathrm{Ni}, \mathrm{Co}, \mathrm{Cr}$, Ti and $\mathrm{V}$ are mainly controlled by the Emeishan basalt and carbonate rock parent materials (Figs. 26-31). We showed in a statistical analysis that the average relative change rates of $\mathrm{Cu}, \mathrm{Ni}, \mathrm{Co}, \mathrm{Cr}, \mathrm{Ti}$ and $\mathrm{V}$ contents in the top soil, with respect to that in the deep soil (defined as (content in the top soil - content in the deep soil) / content in the deep soil) $\times 100$ ) were $-5.9 \%$, $-5.31 \%,-6.09 \%,-6.52 \%,-4.8 \%$ and $-2.58 \%$, respectively, demonstrating that the concentrations of these elements were all slightly lower in the top soil. In a correlation analysis comparing elevation with elemental content, we showed that the rates of $\mathrm{Co}$ and $\mathrm{Ni}$ loss in the top soil increased with increasing elevation (Fig. 32, $a, b$ ). The average rates of change of $\mathrm{Cu}, \mathrm{Cr}, \mathrm{Ti}$ and $\mathrm{V}$ contents in the top soil at different 

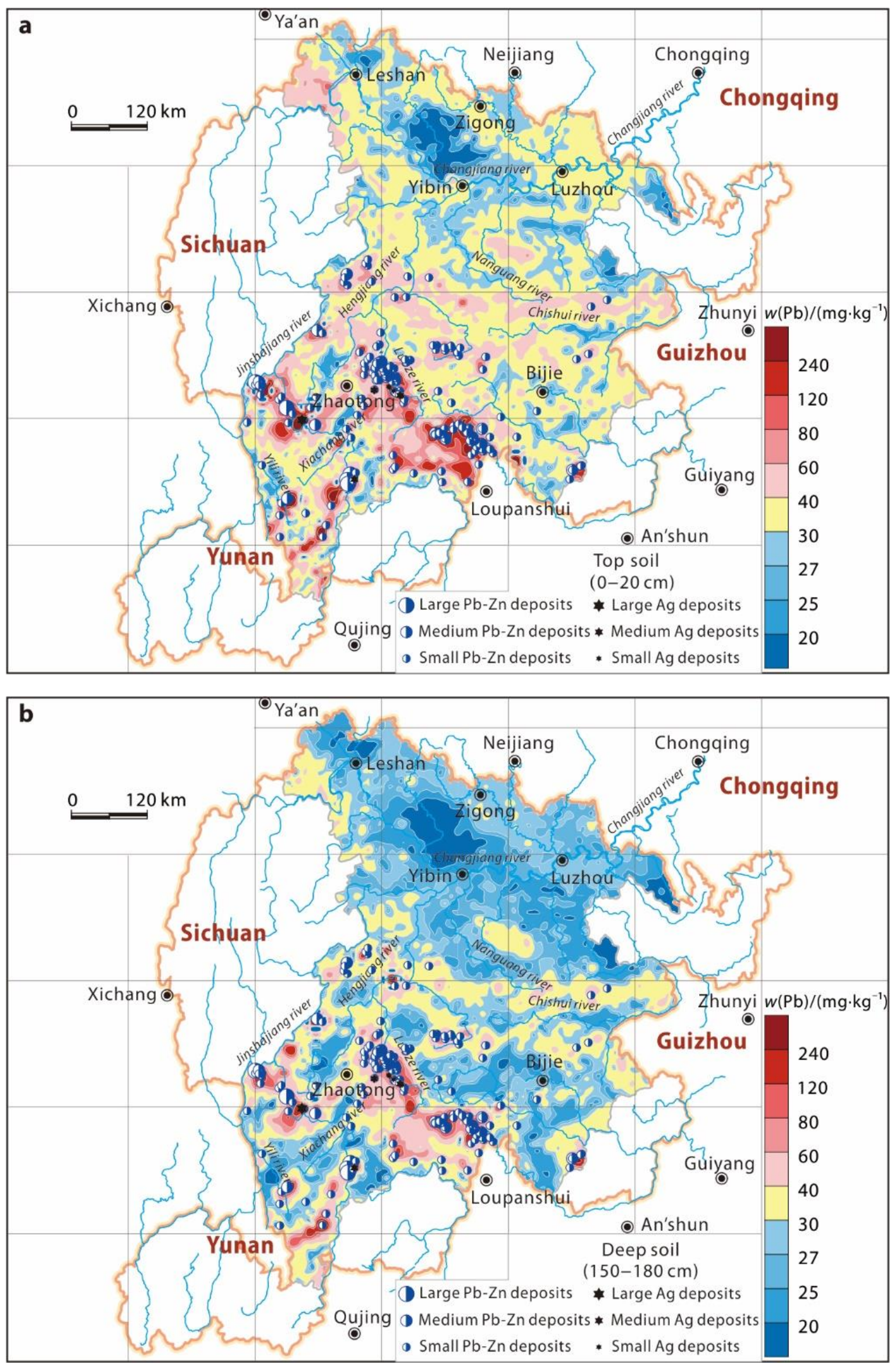

Fig. 20. Lead distribution pattern in the top $(0-20 \mathrm{~cm})$ (a) and deep $(150-180 \mathrm{~cm})(\mathrm{b})$ soils of the Zhaotong - Bijie - Yibin - Luzhou - Leshan area

Puc. 20. Схема распределения $P b$ в верхних (0-20 cм) (a) и глубоких (150-180 cм) (b) почвах в районе Чжаотун - Бицзе - Ибинь - Лучжоу - Лэшань 

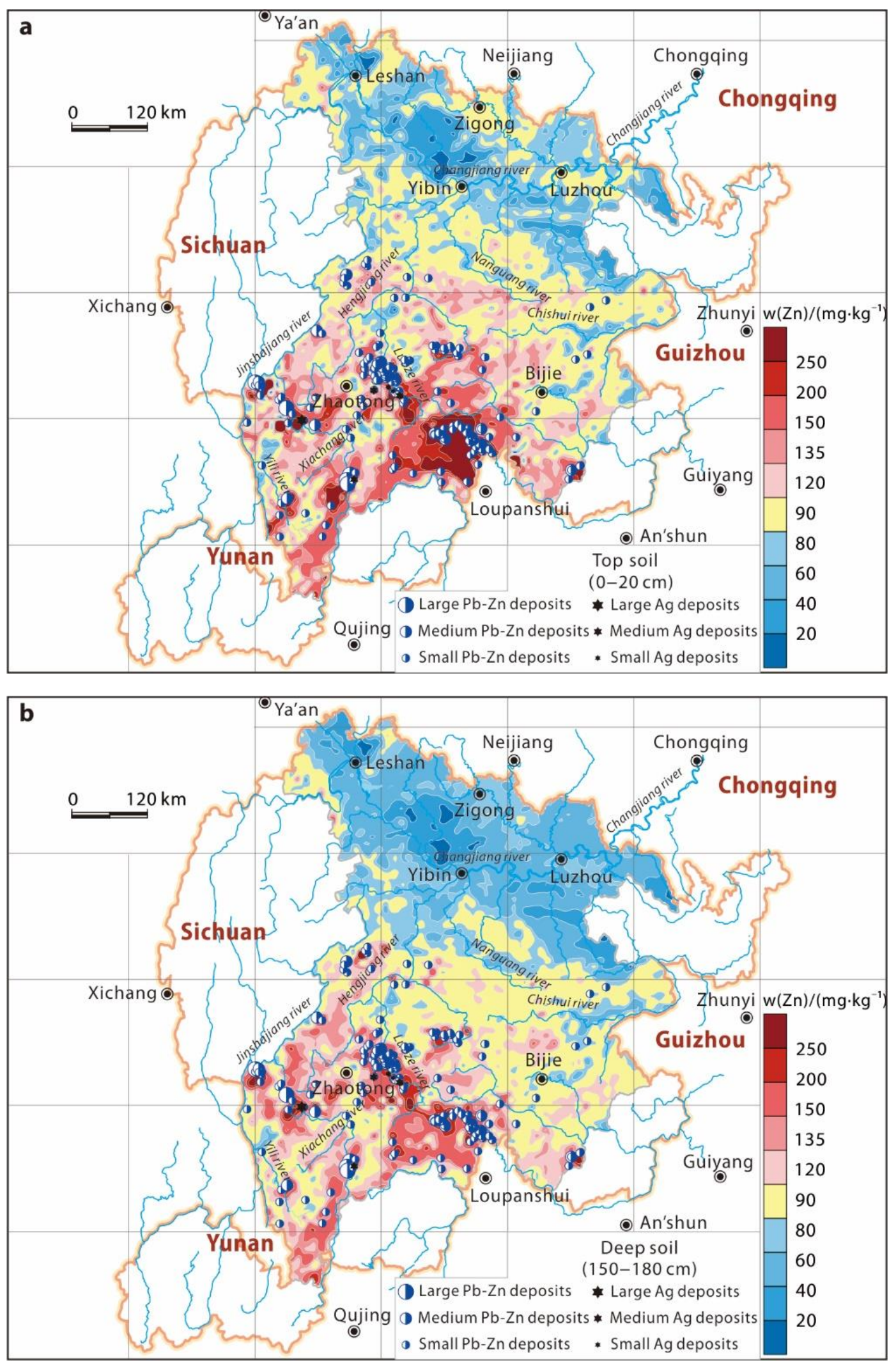

Fig. 21. Zinc distribution pattern in the top $(0-20 \mathrm{~cm})$ (a) and deep $(150-180 \mathrm{~cm})(\mathrm{b})$ soils of the Zhaotong - Bijie - Yibin - Luzhou - Leshan area

Puc. 21. Схема распределения Zn в верхних (0-20 cм) (a) и глубоких (150-180 cм) (b) почвах в районе Чжаотун - Бицзе - Ибинь - Лучжоу - Лэшань 

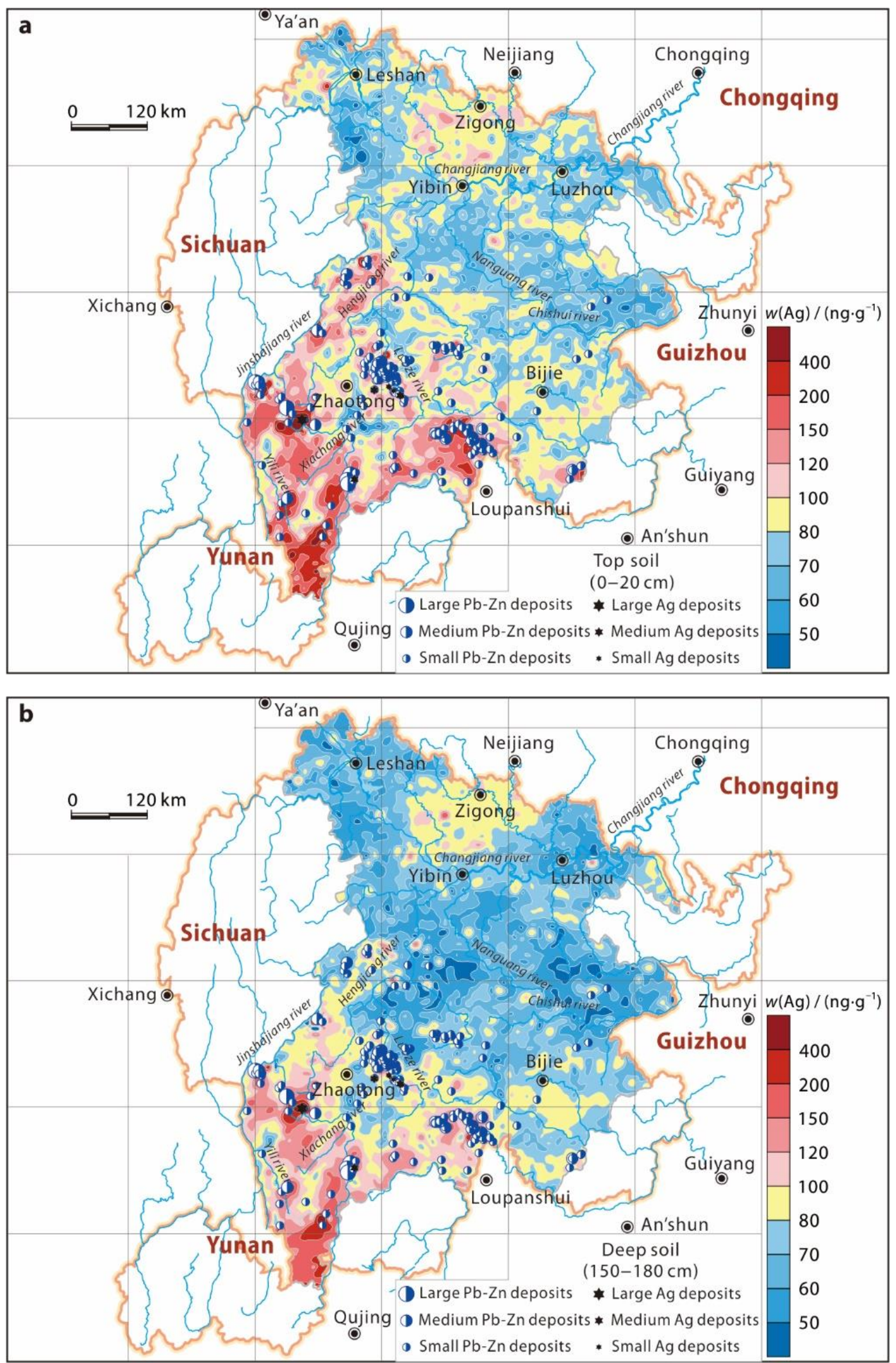

Fig. 22. Silver distribution pattern in the top $(0-20 \mathrm{~cm})$ (a) and deep $(150-180 \mathrm{~cm})(\mathrm{b})$ soils of the Zhaotong - Bijie - Yibin - Luzhou - Leshan area

Puc. 22. Схема распределения Ag в верхних (0-20 см) (a) и глубоких (150-180 см) (b) почвах в районе Чжаотун - Бицзе - Ибинь - Лучжоу - Лэшань 

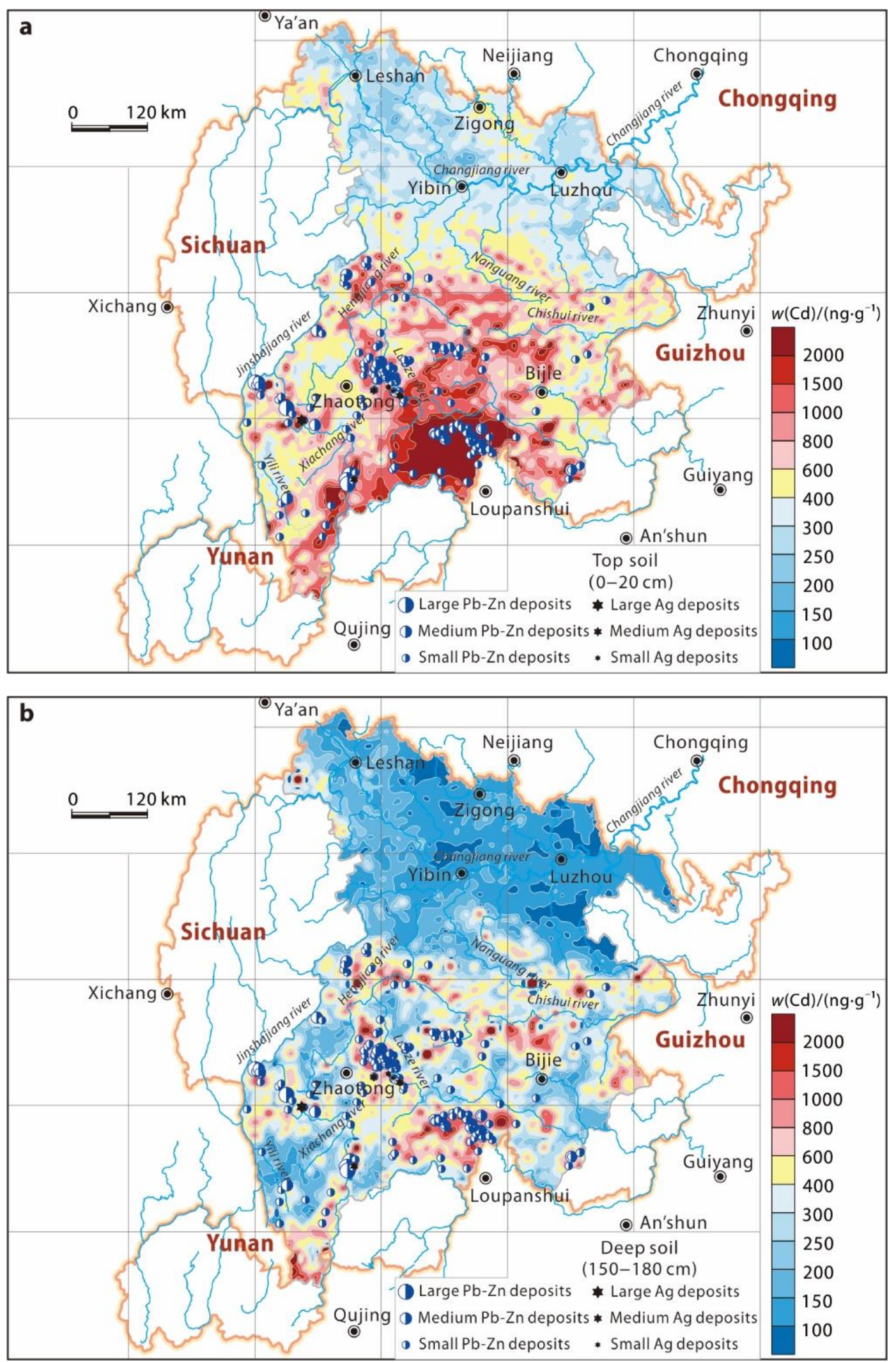

Fig. 23. Cadmium distribution pattern in the top (0-20 cm) (a) and deep $(150-180 \mathrm{~cm})(\mathrm{b})$ soil of the Zhaotong - Bijie - Yibin - Luzhou - Leshan area

Puc. 23. Схема распределения Cd в верхних (0-20 cм) (a) и глубоких (150-180 cм) (b) почвах в районе Чжаотун - Бицзе - Ибинь - Лучжоу - Лэшань 
elevations were relatively consistent (Fig. 32, $c-f$ ), indicating the change of top soil contents of
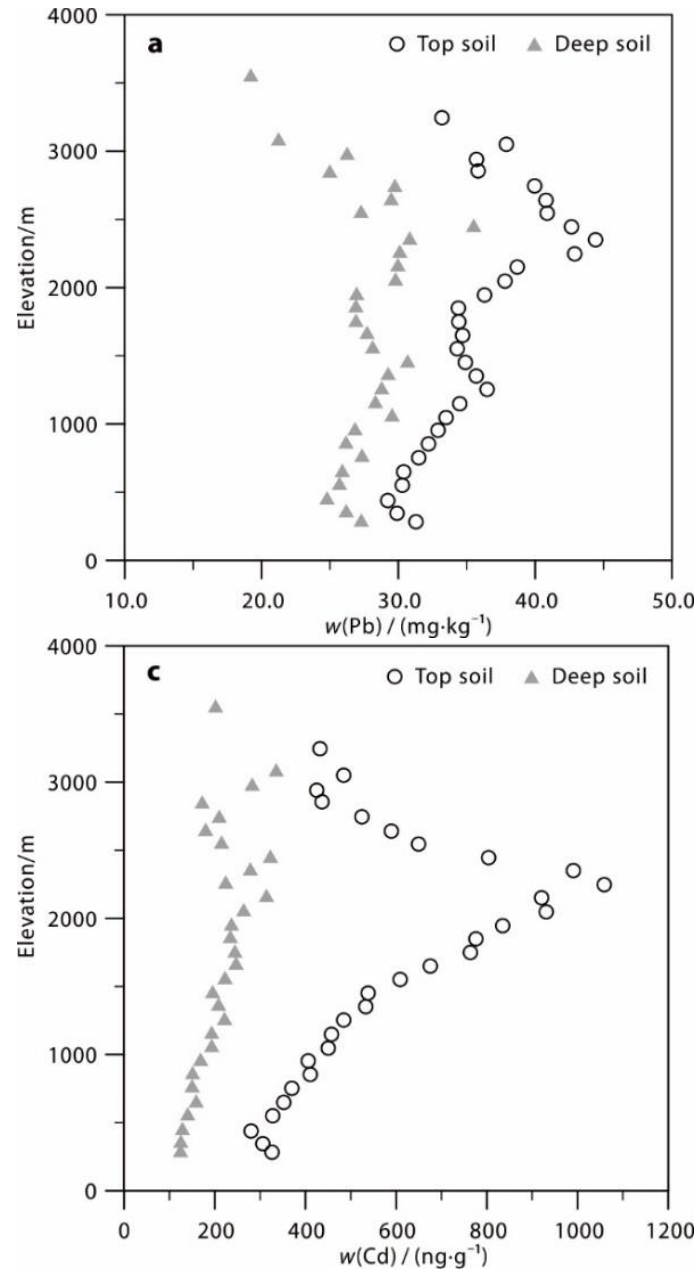

these five elements is essentially controlled by the same factors throughout the region.
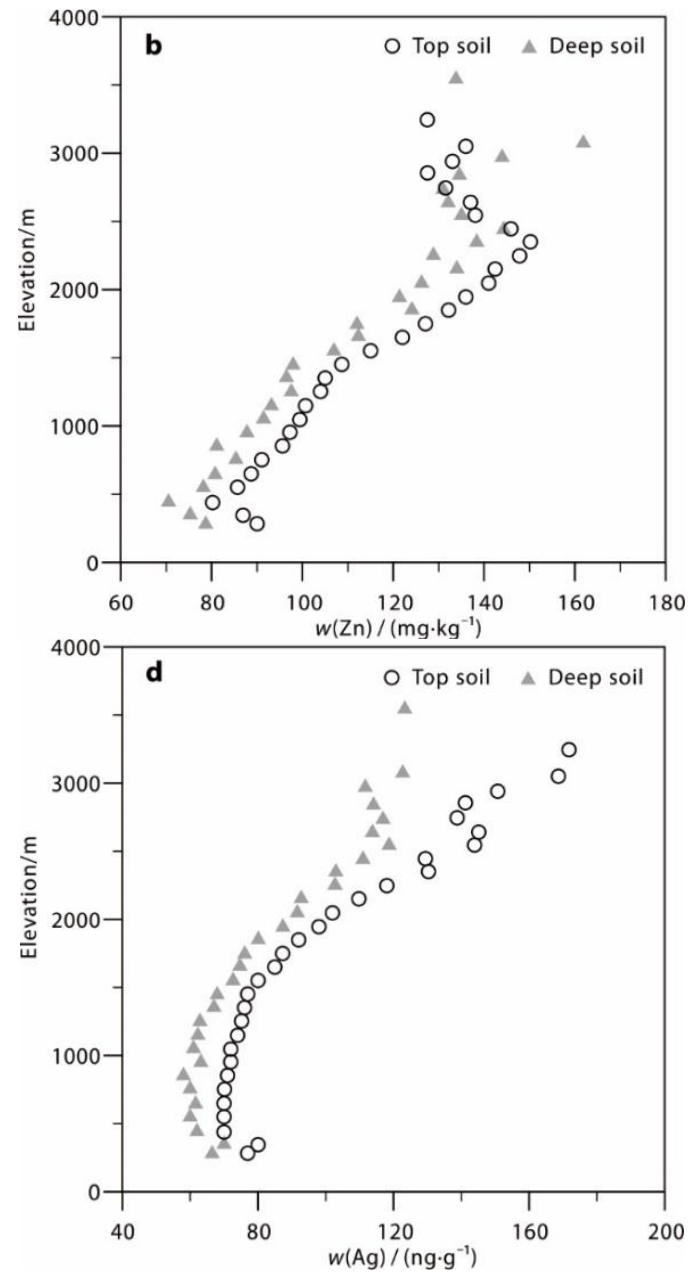

Fig. 24. Plot of $\mathrm{Pb}$ (a), $\mathrm{Zn}(\mathrm{b}), \mathrm{Cd}$ (c) and $\mathrm{Ag}$ (d) contents in the top and deep soils vs. elevation in the Zhaotong - Bijie - Yibin - Luzhou - Leshan area

Puc. 24. График содержания $\mathrm{Pb}(\mathrm{a}), \mathrm{Zn}(\mathrm{b}), \mathrm{Cd}(\mathrm{c})$ u $\mathrm{Ag}(\mathrm{d})$ в верхних и глубоких почвах в зависимости от глубины в районе Чжаотун - Бицзе - Ибинь - Лучжоу - Лэшань

Table 3. Partial correlation analysis of $\mathrm{Pb}, \mathrm{Zn}, \mathrm{Ag}$ and $\mathrm{Cd}$

with respect to $\mathrm{C}_{\text {org }}$ and $\mathrm{pH}$ in soils of the Zhaotong - Bijie - Yibin - Leshan - Luzhou area

Таблица 3. Частичный корреляционный анализ содержаний $\mathrm{Pb}, \mathrm{Zn}, \mathrm{Ag}$ и $\mathrm{Cd}$

в соответствии с содержанием $\mathrm{C}_{\text {org }}$ и pH в почвах района Чжаотун - Бицзе - Ибинь - Лучжоу - Лэшань

\begin{tabular}{|c|c|c|c|}
\hline Element & Test parameters & $\mathrm{pH}$ (constant Corg $_{\text {) }}$ & Corg (constant $\mathrm{pH}$ ) \\
\hline \multirow{3}{*}{$\mathrm{Ag}$} & Correlation & 0.055 & 0.817 \\
\cline { 2 - 4 } & Significance (two-tailed) & 0.784 & 0 \\
\cline { 2 - 4 } & $\mathrm{df}$ & 25 & 25 \\
\hline \multirow{3}{*}{$\mathrm{Cd}$} & Correlation & -0.593 & -0.323 \\
\cline { 2 - 4 } & Significance (two-tailed) & 0.001 & 0.101 \\
\cline { 2 - 4 } & $\mathrm{df}$ & 25 & 25 \\
\hline \multirow{3}{*}{$\mathrm{Pb}$} & Correlation & -0.08 & 0.655 \\
\cline { 2 - 4 } & Significance (two-tailed) & 0.692 & 0 \\
\cline { 2 - 4 } & $\mathrm{df}$ & 25 & 25 \\
\hline \multirow{3}{*}{$\mathrm{Zn}$} & Correlation & -0.583 & -0.257 \\
\cline { 2 - 4 } & Significance (two-tailed) & 0.001 & 0.195 \\
\cline { 2 - 4 } & $\mathrm{df}$ & 25 & 25 \\
\hline
\end{tabular}



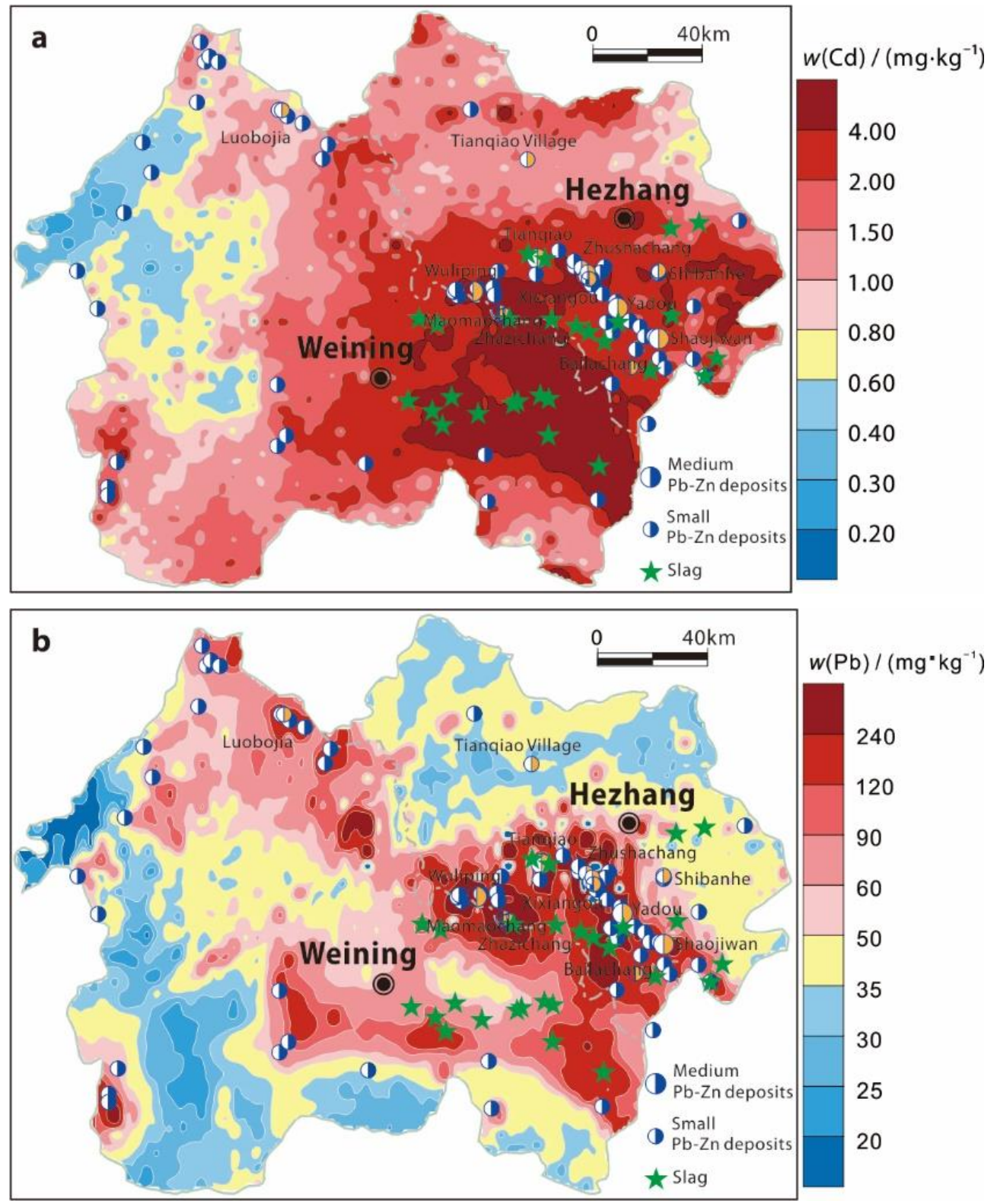

Fig. 25. Geochemical map of the Weining - Hezhang area, showing the locations of $\mathrm{Zn}$ smelting slag (adapted from [19]) and $\mathrm{Cd}$ (a) and $\mathrm{Pb}$ (b) contents in the top soils

Puc. 25. Геохимическая карта района Вейнине - Хечжан с указанием местонахождения цинкового шлака (по данным источника [19]), Cd (a) и Pb (b), содержащихся в верхних почвах

The analysis of driving factors of elemental content (Table 4) demonstrated that, the partial correlation coefficients of $\mathrm{Cu}, \mathrm{Ni}, \mathrm{Co}, \mathrm{Cr}$, Ti and $\mathrm{V}$ with respect to $\mathrm{pH}$, were greater than those to organic carbon. This suggests that the loss of these elements in epigenetic environments is mainly driven by $\mathrm{pH}$.

\section{Conclusions and implications}

Our study on driving mechanisms of the macroscopic distribution of elements in the top and deep soils of the Zhaotong - Bijie - Yibin Luzhou - Leshan region clearly showed the following: the geological environment determines the natural concentrations of chemical elements in soil; epigenetic geochemical processes reshape the microscopic distribution of elements in the top soil; biogeochemical processes drive the evolution of land quality; intensive human activities (such as mining) have disruptive impact on the natural evolution of elemental distribution. A better understanding of the dynamic geochemical processes on the Earth's surface can help to develop a theoretical framework, within which we can study the regional ecology formed through the interactions of topography, hydrology 

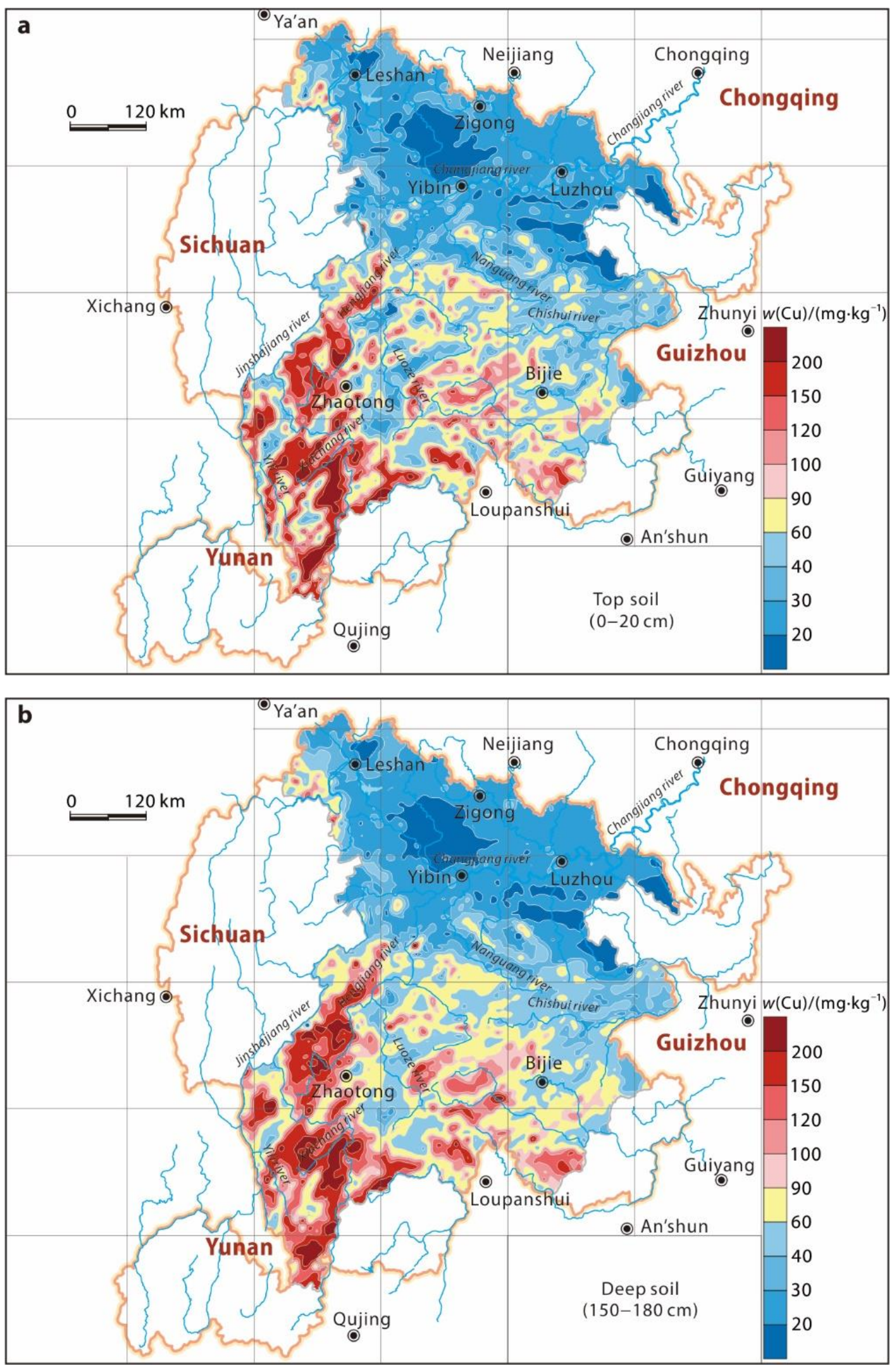

Fig. 26. Copper distribution pattern in the top $(0-20 \mathrm{~cm})(\mathrm{a})$ and deep $(150-180 \mathrm{~cm})(\mathrm{b})$ soils of the Zhaotong - Bijie - Yibin - Luzhou - Leshan area

Puc. 26. Схема распределения Си в верхних (0-20 см) (a) и глубоких (150-180 см) (b) почвах в районе Чжаотун - Бицзе - Ибинь - Лучжоу - Лэшань 

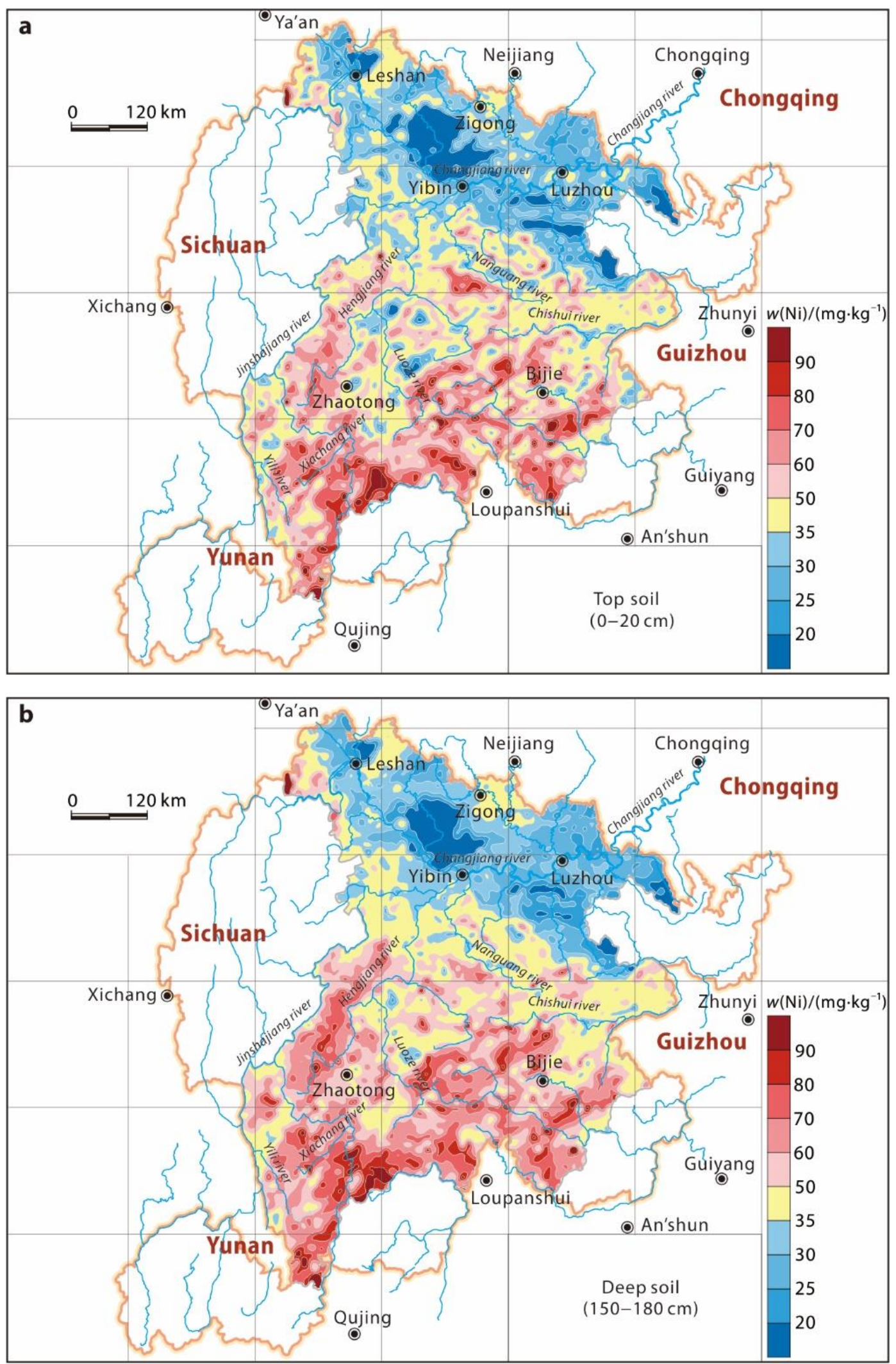

Fig. 27. Nickel distribution pattern in the top $(0-20 \mathrm{~cm})(a)$ and deep $(150-180 \mathrm{~cm})(\mathrm{b})$ soils of the Zhaotong - Bijie - Yibin - Luzhou - Leshan area

Puc. 27. Схема распределения Ni в верхних (0-20 см) (a) и глубоких (150-180 cм) (b) почвах в районе Чжаотун - Бицзе - Ибинь - Лучжоу - Лэшань 

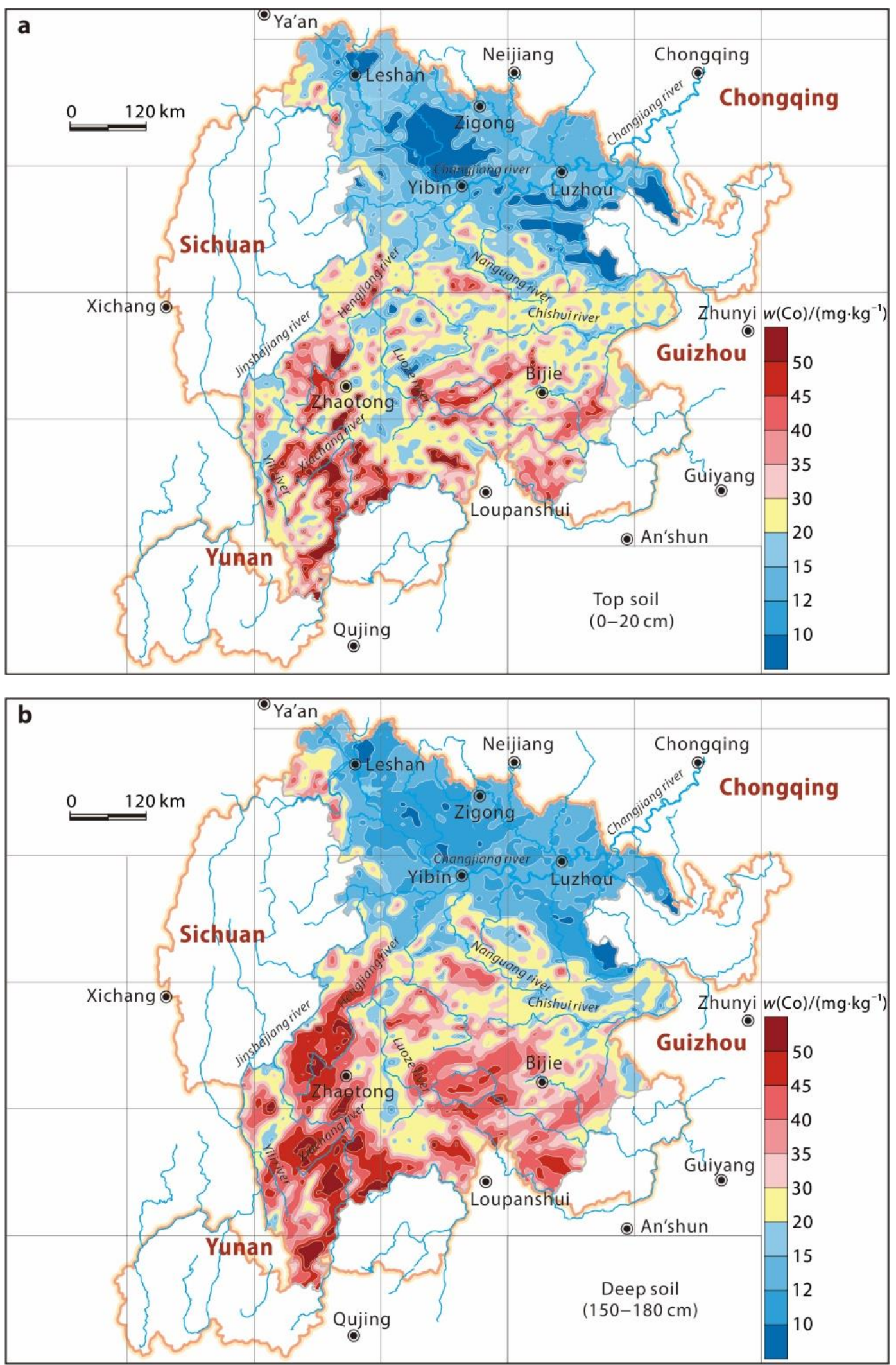

Fig. 28. Cobalt distribution pattern in the top $(0-20 \mathrm{~cm})$ (a) and deep $(150-180 \mathrm{~cm})$ (b) soils of the Zhaotong - Bijie - Yibin - Luzhou - Leshan area

Puc. 28. Схема распределения Со в верхних (0-20 см) (a) и глубоких (150-180 см) (b) почвах в районе Чжаотун - Бицзе - Ибинь - Лучжоу - Лэшань 

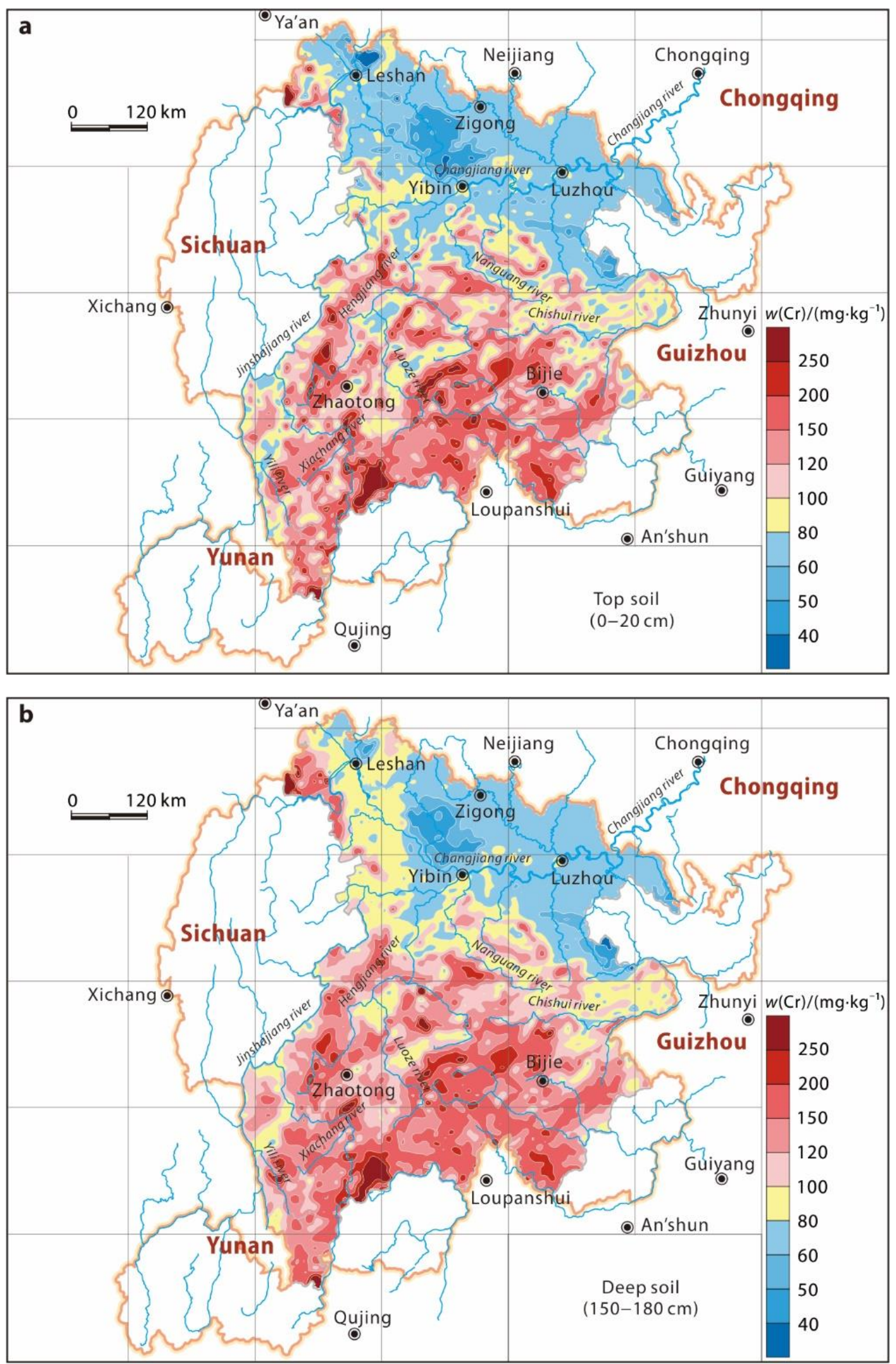

Fig. 29. Chromium distribution pattern in the top $(0-20 \mathrm{~cm})$ (a) and deep $(150-180 \mathrm{~cm})(\mathrm{b})$ soils of the Zhaotong - Bijie - Yibin - Luzhou - Leshan area

Puc. 29. Схема распределения Cr в верхних (0-20 см) (a) и глубоких (150-180 см) (b) почвах в районе Чжаотун - Бицзе - Ибинь - Лучжоу - Лэшань 

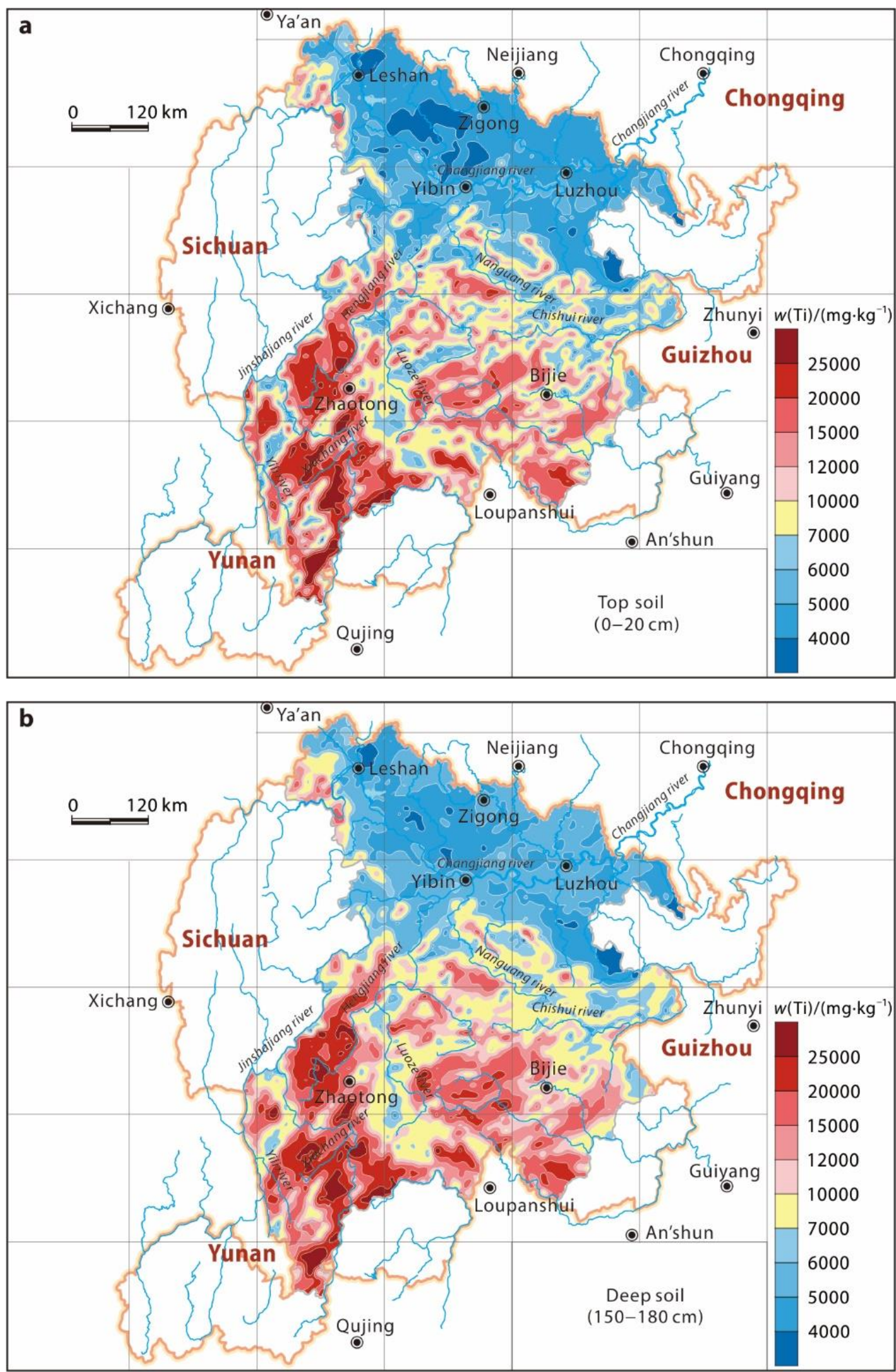

Fig. 30. Titanium distribution pattern in the top $(0-20 \mathrm{~cm})$ (a) and deep $(150-180 \mathrm{~cm})(\mathrm{b})$ soils of the Zhaotong - Bijie - Yibin - Luzhou - Leshan area

Puc. 30. Схема распределения Tі в верхних (0-20 см) (a) и глубоких (150-180 см) (b) почвах в районе Чжаотун - Бицзе - Ибинь - Лучжоу - Лэшань 

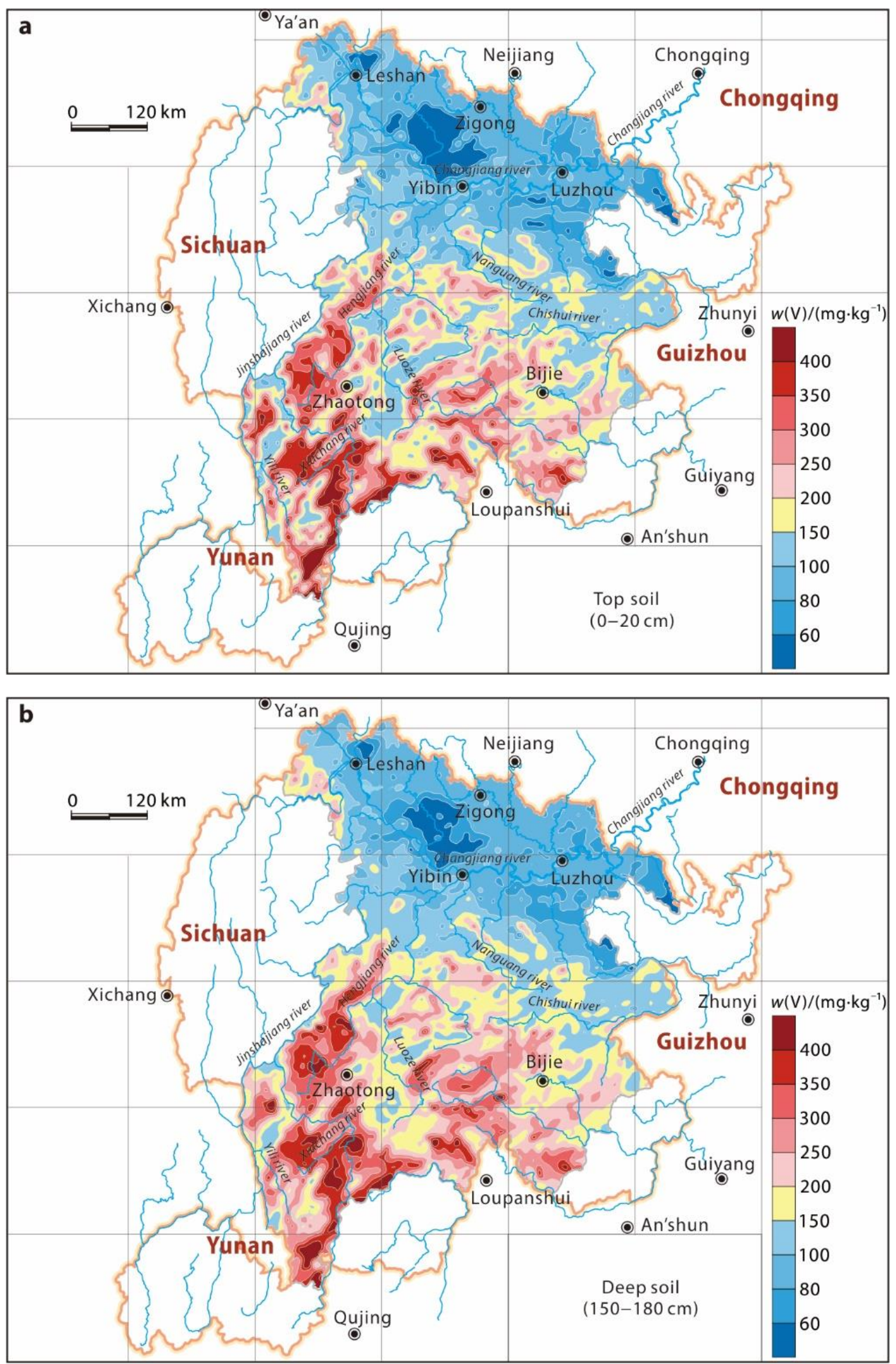

Fig. 31. Vanadium distribution pattern in the top $(0-20 \mathrm{~cm})(\mathrm{a})$ and deep $(150-180 \mathrm{~cm})(\mathrm{b})$ soils of the Zhaotong - Bijie - Yibin - Luzhou - Leshan area

Puc. 31. Схема распределения V в верхних (0-20 см) (a) и глубоких (150-180 см) (b) почвах в районе Чжаотун - Бицзе - Ибинь - Лучжоу - Лэшань 

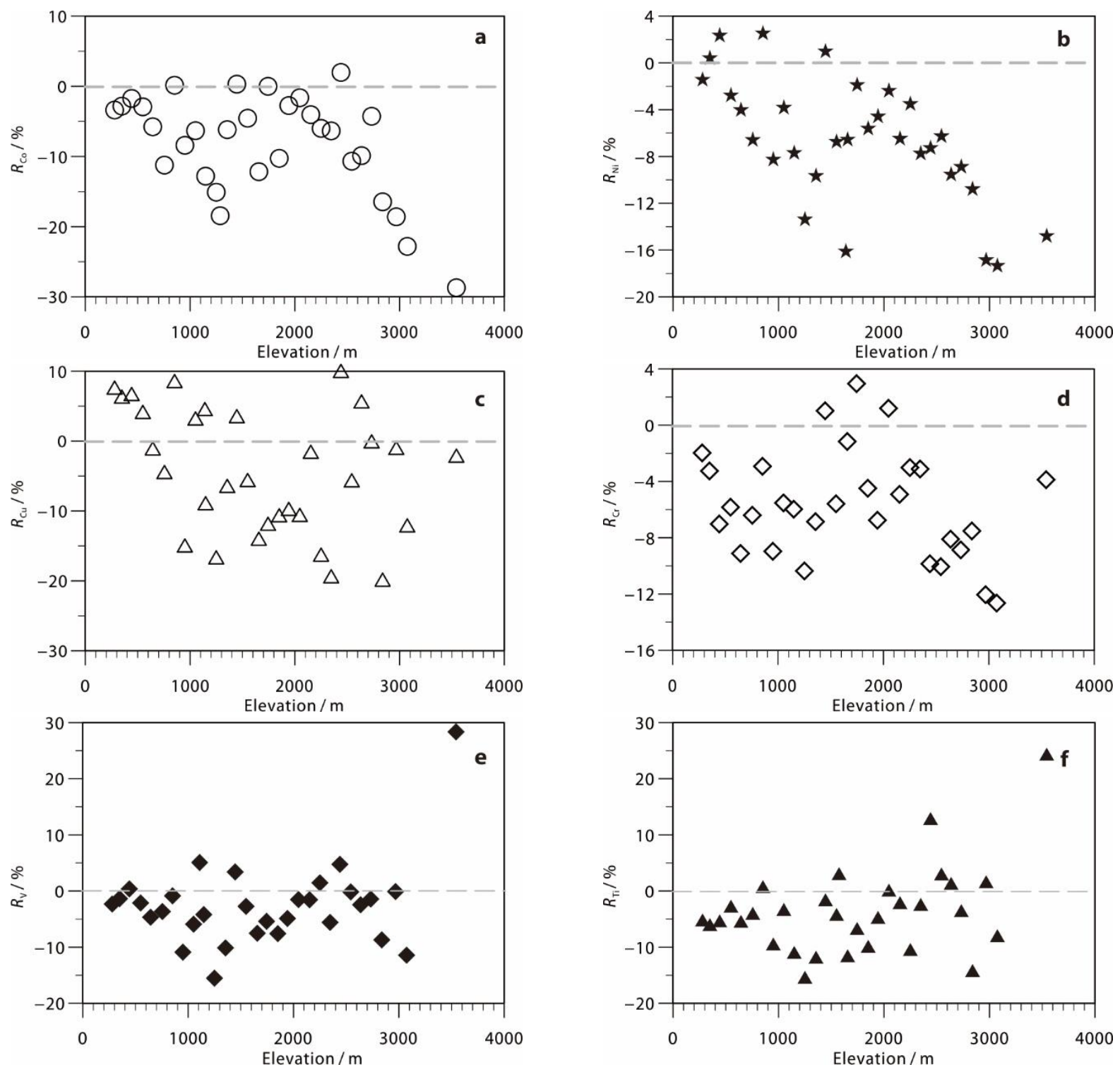

Fig. 32. Relative change rate ( $\left.R_{i}\right)$ of $\mathrm{Co}(\mathrm{a}), \mathrm{Ni}(\mathrm{b}), \mathrm{Cu}(\mathrm{c}), \mathrm{Cr}(\mathrm{d}), \mathrm{V}(\mathrm{e})$ and $\mathrm{Ti}(\mathrm{f})$ contents in the top soil compared to that in the deep soil at different elevations in the Zhaotong - Bijie - Yibin - Luzhou - Leshan area

$R_{i}=(($ content in the top soil - content in the deep soil) / content in the deep soil) $\times 100)$

Puc. 32. Относительная скорость изменения (Ri) содержания Co (a), $\mathrm{Ni}(b), \mathrm{Cu}(c), \mathrm{Cr}(d), \mathrm{V}(\mathrm{e}) \mathrm{u} \mathrm{Ti}(f)$ в верхних почвах по сравнению с глубокими почвами на разных высотах в районе Чжаотун - Бицзе - Ибинь - Лучжоу - Лэшань

$R_{i}=(($ содержание элемента в верхних почвах - содержание элемента в глубоких почвах ( содержание элемента в глубоких почвах) х 100)

and land cover. Such framework has the potential for comprehensively integrating different scientific theories of Earth's systems. To study the physical, chemical and biodynamic processes on the Earth's surface, a new comprehensive survey and monitoring system for mountains, water bodies, forests, farmlands and grasslands is required. This system could help us determine the current natural resource usage, land quality, ecological quality and natural evolution patterns, and assess land quality and future trends, so as to provide guidance for spatial planning and management nationwide.

China is a vast country with complex and diverse geographical landscapes [24]. In this study, we only analyzed the southwestern area characterized by mountains and gorges, and primarily revealed the mechanisms driving the macroscopic distribution of elements in the regional soils. Similar studies should be conducted in 
Table 4. Results of partial correlation analysis of $\mathrm{Cu}, \mathrm{Ni}, \mathrm{Co}, \mathrm{Ti}$ and $\mathrm{V}$ with respect to $\mathrm{pH}$ and $\mathrm{C}_{\text {org }}$ in soil in the Zhaotong - Bijie - Yibin - Luzhou - Leshan area Таблица 4. Результаты частичного корреляционного анализа $\mathrm{Cu}, \mathrm{Ni}, \mathrm{Co}, \mathrm{Ti}$ и V по отношению к рН и $\mathrm{C}_{\text {org }}$ в почвах в районе Чжаотун - Бицзе - Ибинь - Лучжоу - Лэшань

\begin{tabular}{|c|c|c|c|}
\hline Element & Test parameter & $\mathrm{pH}$ (constant $\left.\mathrm{C}_{\text {org }}\right)$ & $\mathrm{C}_{\text {org }}$ (constant $\mathrm{pH}$ ) \\
\hline \multirow{3}{*}{$\mathrm{Cu}$} & Correlation & -0.841 & 0.407 \\
\hline & Significance (two-tailed) & 0 & 0.035 \\
\hline & $\mathrm{df}$ & 25 & 25 \\
\hline \multirow{3}{*}{$\mathrm{Ni}$} & Correlation & -0.588 & -0.337 \\
\hline & Significance (two-tailed) & 0.001 & 0.086 \\
\hline & $\mathrm{df}$ & 25 & 25 \\
\hline \multirow{3}{*}{ Co } & Correlation & -0.741 & -0.504 \\
\hline & Significance (two-tailed) & 0 & 0.007 \\
\hline & $\mathrm{df}$ & 25 & 25 \\
\hline \multirow{3}{*}{$\mathrm{Cr}$} & Correlation & -0.58 & -0.303 \\
\hline & Significance (two-tailed) & 0.002 & 0.124 \\
\hline & $\mathrm{df}$ & 25 & 25 \\
\hline \multirow{3}{*}{$\mathrm{Ti}$} & Correlation & -0.847 & 0.403 \\
\hline & Significance (two-tailed) & 0 & 0.037 \\
\hline & $\mathrm{df}$ & 25 & 25 \\
\hline \multirow{3}{*}{ V } & Correlation & -0.769 & 0.272 \\
\hline & Significance (two-tailed) & 0 & 0.169 \\
\hline & $\mathrm{df}$ & 25 & 25 \\
\hline
\end{tabular}

future to analyze a variety of landscapes, including forests and swampy landscapes, humid and semi-humid low mountains, semi-arid hilly landscapes, alpine lakes in hilly landscapes, arid and semi-arid or humid and semi-humid alpine mountains, arid Gobi relict mountains, karst areas, alluvial plains, and colluvial deposits in the Gobi desert. Such studies would represent considerable advances in epigenetic geochemical dynamics and help us to establish a solid foundation for the development of scientific theories of the Earth's systems [25, 26].

Currently, surveys on the quantity, quality and ecological status of various natural resources in China are disconnected rather than combined in a single system. Presently, the Ministry of Natural Resources is responsible for all natural resource assets. It formulates land use regulations and conducts ecological protection and restoration. However, a comprehensive survey and monitoring system, integrating the quantity, quality and ecological conditions of all natural resources based on their various transport patterns, remains to be developed. Moreover, chemical elements are the basic components of natural resources. For example, our findings on the epigenetic geochemical dynamic processes and mutual interactions of resources components, in the southwestern mountain and gorge regions, suggest that changes in chemical elemental contents in the environment are extremely sensitive indicators of environmental changes. Hence, we recommend that the chemical compositions of natural resources should also be included in the procedures during the development of future survey and monitoring systems.

\section{References}

1. Hou Z. Support unified management and system restoration of natural resources based on earth system science. China Natural Resources News. 12.06.2018.

2. Li K, Peng M, Zhao C, et al. Twenty years of geochemical survey of national land quality. Earth Science Frontiers. 2019;26(5):1-37.

3. Yang $X$, Wang $P$, Gao D. Climate change characteristics of Wumengshan National Nature Reserve from 1971 to 2015. Journal of Northeast Forestry University. 2019;47(9):71-75.

4. Ji Z, Huang Z, Xie G. Dry and wet climate changes in Yunnan from 1961 to 2010. Meteorological Science and Technology. 2013;41(6):1073-1079.

5. Xiao K, Xing S, Ding J, et al. Division of key mineralization zones of important solid minerals and characteristics of resource potential in China. Acta Geologica Sinica. 2016;90(7):1269-1280. 
6. He L, Wu D, Zhao F, et al. Geological characteristics and ore prospecting model and ore prospecting direction of Hezhang Zhugongtang ultra-large lead-zinc deposit. Guizhou Geology. 2019;36(2):106-109.

7. Xu Y, Zhong Y, Wei X, Chen J., Liu H., Xie W., et al. Evolution of Permian mantle plumes and surface systems. Bulletin of Mineralogy, Petrology and Geochemistry. 2017;36(3):359-373.

8. Lin J. Spatiotemporal distribution and geological characteristics of the Permian basalt in the three provinces of Southwest China. Chinese Science Bulletin. 1985;30(12):929-932.

9. Ye J, Yao L. Discussions on the quality control method of regional geochemical survey sample analysis. Rock and Mineral Analysis. 2004;23(2):137-142.

10. Wang S, Ji H, Ouyang Z, et al. Preliminary study on the weathering of carbonate rocks. Science in China. Series D. 1999;29(5):441-449.

11. Zhu L, Li J. Weathering of carbonate rocks and its environmental effects. Beijing: Geological Publishing House; 2004. $131 \mathrm{p}$.

12. Darnley AG, Björklund A, Bølviken B, Gustavsson N., Koval P.V., Plant J.A., et al. A global geochemical database for environmental and resource management. Paris: UNESCO Publishing; 1995. $122 \mathrm{p}$.

13. Cui Z, Zhang $H$, Chen $X$, Zhang $C$, Ma W, Huang $C$, et al. Pursuing sustainable productivity with millions of smallholder farmers. Nature. 2018;555(7696):363-366. https://doi.org/10.1038/nature25785

14. Hu Y, Li C, Wen H, et al. Characteristics of silver minerals in the lead-zinc-silver deposits at the junction of Sichuan, Yunnan, and Guizhou. Bulletin of Mineralogy, Petrology and Geochemistry. 2000;19(4):318-320.

15. Fuge R, Johnson $C$. The geochemistry of iodine: a review. Environmental Geochemistry and Health. 1986;8(2):31-54. https://doi.org/10.1007/BF02311063

16. Muramatsu Y, Yoshida S, Fehn U, Amachi S, Ohmomo Y. Studies with natural and anthropogenic iodine isotopes: iodine distribution and cycling in the global environment. Journal of Environmental Radioactivity. 2004;74(1-3):221-232. https://doi.org/10.1016/J.JENVRAD. 2004.01.011
17. Yamaguchi N, Nakano M, Takamatsu R, Tanida H. Inorganic iodine incorporation into soil organic matter: evidence from iodine K-edge X-ray absorption near-edge structure. Journal of Environmental Radioactivity. 2010;101(6):451-457. https://doi.org/10.1016/j.jenvrad. 2008.06.003

18. Fuge R. Soils and lodine Deficiency. In: Selinus $O$ (eds.). Essentials of medical geology: impacts of the natural environment on public health. Dordrecht: Springer Netherlands; 2013. p.417-432.

19. Peng Y. Study on the distribution and migration of heavy metals in slag, soil and plants in the indigenous zinc smelting district of Northwest Guizhou. Guiyang: Guizhou University; 2018.

20. Li Z, Feng X, Bi X, et al. Pollution status of heavy metals in soil on an indigenous zinc smelting site in Guizhou Province. Chinese Journal of Ecology. 2011;30(5):55-59.

21. Chen F, Dong Z, Wang C, et al. Pollution status and risk assessment of heavy metals in cultivated soil and crops in zinc smelting area. Environmental Science. 2017;38(10):376-385.

22. Li J, Zhong H, Zhu WG, Bai ZJ, Hu W. Elemental and $\mathrm{Sr}-\mathrm{Nd}$ isotopic geochemistry of Permian Emeishan flood basalts in Zhaotong, Yunnan Province, SW China. International Journal of Earth Science. 2017;106(2):617630. https://doi.org/10.1007/s00531-016-1326-z

23. Chung SL, Jahn BM. Plume-lithosphere interaction in generation of the Emeishan flood basalts at the Permian-Triassic boundary. Geology. 1995;23(10):889-892. https://doi.org/10.1130/0091-7613(1995)023<0889:PLIIGO> 2.3.CO;2

24. Xie X, Ren T. National geochemical mapping and environmental geochemistry - progress in China. Journal of Geochemical Exploration. 1993;49(1-2):15-34. https://doi.org/10.1016/0375-6742(93)90037-M

25. Lawton J. Earth system science. Science. 2001;292(5524):1965. https://doi.org/10.1126/science. 292.5524 .1965

26. Bockheim JG, Gennadiyev AN. Soil-factorial models and earth-system science: a review. Geoderma. 2010;159(3-4):243-251.

\section{Библиографический список}

1. Hou Z. Support unified management and system restoration of natural resources based on earth system science // China Natural Resources News. 12.06.2018.

2. Li K., Peng M., Zhao C., et al. Twenty years of geochemical survey of national land quality // Earth Science Frontiers. 2019. Vol. 26. Iss. 5. P. 1-37.

3. Yang X., Wang P., Gao D. Climate change characteristics of Wumengshan National Nature Reserve from 1971 to 2015 // Journal of Northeast Forestry University. 2019. Vol. 47. Iss. 9. P. 71-75.

4. Ji Z., Huang Z., Xie G. Dry and wet climate changes in Yunnan from 1961 to 2010 // Meteorological Science and Technology. 2013. Vol. 41. Iss. 6. P. 1073-1079.

5. Xiao K., Xing S., Ding J., et al. Division of key mineralization zones of important solid minerals and characteristics of resource potential in China // Acta Geologica Sinica. 2016. Vol. 90. Iss. 7. P. 1269-1280.

6. He L., Wu D., Zhao F., et al. Geological characteristics and ore prospecting model and ore prospecting direction of Hezhang Zhugongtang ultra-large lead-zinc deposit // Guizhou Geology. 2019. Vol. 36. Iss. 2. P. 106-109.

7. Xu Y., Zhong Y., Wei X., Chen J., Liu H., Xie W., et al. Evolution of Permian mantle plumes and surface systems // Bulletin of Mineralogy, Petrology and Geochemistry. 2017. Vol. 36. Iss. 3. P. 359-373.

8. Lin J. Spatiotemporal distribution and geological characteristics of the Permian basalt in the three provinces of Southwest China // Chinese Science Bulletin. 1985. Vol. 30. Iss. 12. P. 929-932. 
9. Ye J., Yao L. Discussions on the quality control method of regional geochemical survey sample analysis. Rock and Mineral Analysis. 2004;23(2):137-142.

10. Wang S., Ji H., Ouyang Z., et al. Preliminary study on the weathering of carbonate rocks // Science in China. Series D. 1999. Vol. 29. Iss. 5. P. 441-449.

11. Zhu L., Li J. Weathering of carbonate rocks and its environmental effects. Beijing: Geological Publishing House, 2004. $131 \mathrm{p}$.

12. Darnley A.G., Björklund A., Bølviken B., Gustavsson N., Koval P.V., Plant J.A., et al. A global geochemical database for environmental and resource management. Paris: UNESCO Publishing, 1995. $122 \mathrm{p}$.

13. Cui Z., Zhang H., Chen X., Zhang C., Ma W., Huang C., et al. Pursuing sustainable productivity with millions of smallholder farmers // Nature. 2018. Vol. 555. Iss. 7696. P. 363-366. https://doi.org/10.1038/nature25785

14. Hu Y., Li C., Wen H., et al. Characteristics of silver minerals in the lead-zinc-silver deposits at the junction of Sichuan, Yunnan, and Guizhou // Bulletin of Mineralogy, Petrology and Geochemistry. 2000. Vol. 19. Iss. 4. P. 318-320.

15. Fuge R., Johnson C. The geochemistry of iodine: a review // Environmental Geochemistry and Health. 1986. Vol. 8. Iss. 2. P. 31-54. https://doi.org/10.1007/BF02311063

16. Muramatsu Y., Yoshida S., Fehn U., Amachi S., Ohmomo Y. Studies with natural and anthropogenic iodine isotopes: iodine distribution and cycling in the global environment // Journal of Environmental Radioactivity. 2004. Vol. 74. Iss. 1-3. P. 221-232. https://doi.org/10.1016/ J.JENVRAD.2004.01.011

17. Yamaguchi N., Nakano M., Takamatsu R., Tanida $\mathrm{H}$. Inorganic iodine incorporation into soil organic matter: evidence from iodine K-edge X-ray absorption near-edge structure // Journal of Environmental Radioactivity. 2010. Vol. 101. Iss. 6. P. 451-457. https://doi.org/10.1016/ j.jenvrad.2008.06.003
18. Fuge R. Soils and lodine Deficiency // Essentials of medical geology: impacts of the natural environment on public health / eds. O. Selinus. Dordrecht: Springer Netherlands, 2013. P. 417-432.

19. Peng Y. Study on the distribution and migration of heavy metals in slag, soil and plants in the indigenous zinc smelting district of Northwest Guizhou. Guiyang: Guizhou University, 2018.

20. Li Z., Feng X., Bi X., et al. Pollution status of heavy metals in soil on an indigenous zinc smelting site in Guizhou Province // Chinese Journal of Ecology. 2011. Vol. 30. Iss. 5. P. 55-59.

21. Chen F., Dong Z., Wang C., et al. Pollution status and risk assessment of heavy metals in cultivated soil and crops in zinc smelting area // Environmental Science. 2017. Vol. 38. Iss. 10. P. 376-385.

22. Li J., Zhong H., Zhu W.G., Bai Z.J., Hu W. Elemental and Sr-Nd isotopic geochemistry of Permian Emeishan flood basalts in Zhaotong, Yunnan Province, SW China // International Journal of Earth Science. 2017. Vol. 106. Iss. 2. P. 617-630. https://doi.org/10.1007/s00531016-1326-z

23. Chung S.L., Jahn B.M. Plume-lithosphere interaction in generation of the Emeishan flood basalts at the Permian-Triassic boundary // Geology. 1995. Vol. 23. Iss. 10. P. 889-892. https://doi.org/10.1130/00917613(1995)023<0889:PLIIGO>2.3.CO;2

24. Xie X., Ren T. National geochemical mapping and environmental geochemistry - progress in China // Journal of Geochemical Exploration. 1993. Vol. 49. Iss. 1-2. P. 15-34. https://doi.org/10.1016/0375-6742(93)90037-M

25. Lawton J. Earth system science // Science. 2001. Vol. 292. Iss. 5524. P. 1965. https://doi.org/10.1126/science.292.5524.1965

26. Bockheim J.G., Gennadiyev A.N. Soil-factorial models and earth-system science: a review /I Geoderma. 2010. Vol. 159. Iss. 3-4. P. 243-251. https://doi.org/10.1016/j.geoderma.2010.09.005

\section{Authorship criteria / Критерии авторства}

Hangxin Cheng, Min Peng, Chuandong Zhao, Wei Han, Huiyan Wang, Qiaolin Wang, Fan Yang, Fugui Zhang, Chengwen Wang, Fei Liu, Yalong Zhou, Shiqi Tang, Kuo Li, Ke Yang, Zheng Yang, Xiaomeng Cheng, Ziwan Chen, Hua Zhang, Chunhu Mo are the authors of the article, hold equal copyright and bear equal responsibility for plagiarism.

Чэн Хансинь, Пэн Минь, Чжао Чуаньдун, Хань Вэй, Ван Хуйянь, Ван Цяолинь, Ян Фань, Чжан Фугуй, Ван Чэнвэнь, Лю Фэй, Чжоу Ялун, Тан Шици, Ли Ко, Ян Кэ, Ян Чжэн, Чэн Сяомэн, Чэнь Цзывань, Чжан Хуа, Мо Чуньху написали статью, имеют равные авторские права и несут одинаковую ответственность за плагиат.

\section{Responsibility for plagiarism / Конфликт интересов}

The authors declare that there is no conflict of interest regarding the publication of this article.

Авторы заявляют об отсутствии конфрликта интересов.

All authors have read and approved the final version of this manuscript.

Bсе авторы прочитали и одобрили окончательный вариант рукописи. 


\section{Information about the authors / Сведения об авторах}

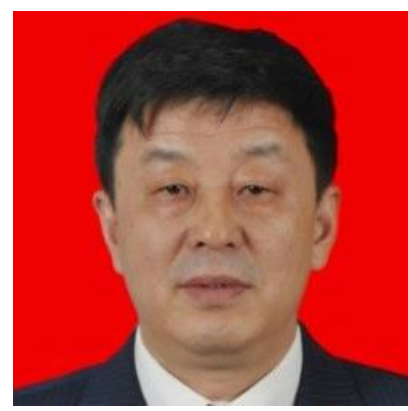

Hangxin Cheng,

Doctor's Degree,

Professor,

Institute of Geophysical \& Geochemical Exploration,

Chinese Academy of Geological Sciences,

84 Jinguang Road, Langfang 065000, China,

$\triangle$ e-mail: 916679036@qq.com

\section{Чэн Хансинь,}

\section{доктор,}

профресcop,

Институт геофизических и геохимических исследований

Китайской академии геологических наук,

065000, г. Ланфан, ул. Цзиньгуан Роуд, 84, Китай,

$\triangle$ e-mail:916679036@qq.com

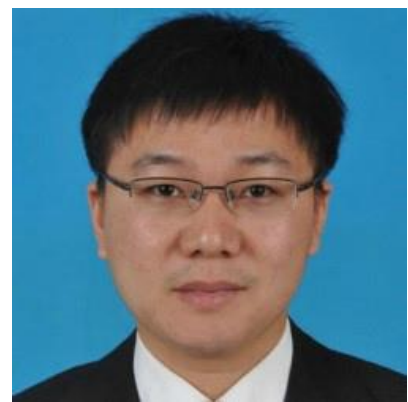

\section{Min Peng,}

Master's Degree,

Engineer,

Institute of Geophysical \& Geochemical Exploration,

Chinese Academy of Geological Sciences,

84 Jinguang Road, Langfang 065000, China,

School of Geosciences and Resources,

China University of Geosciences (Beijing),

29 Xueyuan Road, Beijing 100083, China,

e-mail:pm-ant@qq.com

\section{Пэн Минь,}

\section{магистр,}

инженер,

Институт геофизических и геохимических исследований

Китайской академии геологических наук,

065000, г. Ланфан, ул. Цзиньгуан Роуд, 84, Китай,

Школа геологических наук и природных ресурсов,

Китайский геологический университет (Пекин),

100083, г. Пекин, ул. Сюеюань Роуд, 29, Китай,

e-mail:pm-ant@qq.com

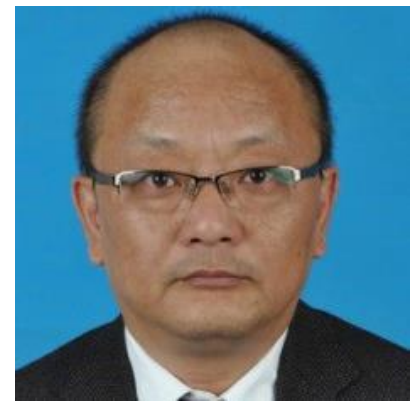

\section{Chuandong Zhao,}

Doctor's Degree,

Professor,

Institute of Geophysical \& Geochemical Exploration,

Chinese Academy of Geological Sciences,

84 Jinguang Road, Langfang 065000, China,

e-mail: Zhaochuandong@igge.cn

Чжао Чуаньдун,

доктор,

профресcop,

Институт геофизических и геохимических исследований

Китайской академии геологических наук,

065000, г. Ланфан, ул. Цзиньгуан Роуд, 84, Китай,

e-mail: Zhaochuandong@igge.cn

\section{Wei Han,}

Master's Degree,

Engineer,

Institute of Geophysical \& Geochemical Exploration, Chinese Academy of Geological Sciences,

84 Jinguang Road, Langfang 065000, China,

e-mail:331224192@qq.com 
Хань Вэй,

магистр,

инженер,

Институт геофизических и геохимических исследований Китайской академии геологических наук, 065000 , г. Ланфран, ул. Цзиньгуан Роуд, 84, Китай,

e-mail: 331224192@qq.com

\section{Huiyan Wang,}

Master's Degree,

Engineer,

Institute of Geophysical \& Geochemical Exploration, Chinese Academy of Geological Sciences,

84 Jinguang Road, Langfang 065000, China,

e-mail: wanghuiyan@igge.cn

\section{Ван Хуйянь,}

магистр,

инженер,

Институт геофизических и геохимических исследований Китайской академии геологических наук, 065000 , г. Ланфран, ул. Цзиньгуан Роуд, 84, Китай,

e-mail: wanghuiyan@igge.cn

\section{Qiaolin Wang,}

Master's Degree,

Engineer,

Institute of Geophysical \& Geochemical Exploration, Chinese Academy of Geological Sciences,

84 Jinguang Road, Langfang 065000, China,

e-mail: 408409647@qq.com

\section{Ван Цяолинь,}

магистр,

инженер,

Институт геофизических и геохимических исследований Китайской академии геологических наук, 065000, г. Ланфран, ул. Цзиньгуан Роуд, 84, Китай,

e-mail: 408409647@qq.com

\section{Fan Yang,}

Doctor's Degree,

Senior Engineer,

Institute of Geophysical \& Geochemical Exploration, Chinese Academy of Geological Sciences,

84 Jinguang Road, Langfang 065000, China,

e-mail: yangfan@igge.cn

\section{Ян Фань,}

доктор,

старший инженер,

Институт геофизических и геохимических исследований Китайской академии геологических наук, 065000, г. Ланфран, ул. Цзиньгуан Роуд, 84, Китай,

e-mail: yangfan@igge.cn

\section{Fugui Zhang,}

Master's Degree,

Senior Engineer,

Institute of Geophysical \& Geochemical Exploration, Chinese Academy of Geological Sciences,

84 Jinguang Road, Langfang 065000, China,

e-mail: zhangfugui@igge.cn

\section{Чжан Фугуй,}

магистр,

старший инженер,

Институт геофизических и геохимических исследований Китайской академии геологических наук, 065000, г. Ланфран, ул. Цзиньгуан Роуд, 84, Китай,

e-mail: zhangfugui@igge.cn 


\section{Chengwen Wang,}

Master's Degree,

Engineer,

Institute of Geophysical \& Geochemical Exploration, Chinese Academy of Geological Sciences,

84 Jinguang Road, Langfang 065000, China,

e-mail: 187311220@qq.com

\section{Ван Чэнвэнь,}

магистр,

инженер,

Институт геофизических и геохимических исследований Китайской академии геологических наук, 065000, г. Ланфран, ул. Цзиньгуан Роуд, 84, Китай,

e-mail:187311220@qq.com

\section{Fei Liu,}

Doctor's Degree,

Senior Engineer,

Institute of Geophysical \& Geochemical Exploration, Chinese Academy of Geological Sciences,

84 Jinguang Road, Langfang 065000, China,

e-mail:29619105@qq.com

Лю Фэй,

доктор,

старший инженер,

Институт геофизических и геохимических исследований Китайской академии геологических наук, 065000, г. Ланфан, ул. Цзиньгуан Роуд, 84, Китай,

e-mail:29619105@qq.com

\section{Yalong Zhou,}

Master's Degree,

Senior Engineer,

Institute of Geophysical \& Geochemical Exploration, Chinese Academy of Geological Sciences,

84 Jinguang Road, Langfang 065000, China,

e-mail: zhouyalong@igge.cn

Чжоу Ялун,

магистр,

старший инженер,

Институт геофизических и геохимических исследований Китайской академии геологических наук, 065000, г. Ланфан, ул. Цзиньгуан Роуд, 84, Китай,

e-mail: zhouyalong@igge.cn

\section{Shiqi Tang,}

Master's Degree,

Assistant Engineer,

Institute of Geophysical \& Geochemical Exploration, Chinese Academy of Geological Sciences,

84 Jinguang Road, Langfang 065000, China,

e-mail: 642191779@qq.com

Тан Шици,

магистр,

ассистент инженера,

Институт геофизических и геохимических исследований Китайской академии геологических наук, 065000, г. Ланфан, ул. Цзиньгуан Роуд, 84, Китай,

e-mail:642191779@qq.com

\section{Kuo Li,}

Master's Degree,

Engineer,

Institute of Geophysical \& Geochemical Exploration, Chinese Academy of Geological Sciences,

84 Jinguang Road, Langfang 065000, China,

e-mail: likuo@igge.cn 


\section{Ли Ко,}

магистр,

инженер,

Институт геофизических и геохимических исследований Китайской академии геологических наук, 065000, г. Ланфан, ул. Цзиньгуан Роуд, 84, Китай,

e-mail: likuo@igge.cn

\section{Ke Yang,}

Doctor's Degree,

Senior Engineer,

Institute of Geophysical \& Geochemical Exploration, Chinese Academy of Geological Sciences,

84 Jinguang Road, Langfang 065000, China,

e-mail: 47384668@qq.com

\section{Ян Кэ,}

доктор,

старший инженер,

Институт геофизических и геохимических исследований Китайской академии геологических наук, 065000 , г. Ланфан, ул. Цзиньгуан Роуд, 84, Китай,

e-mail: 47384668@qq.com

\section{Zheng Yang,}

Master's Degree,

Assistant Engineer,

Institute of Geophysical \& Geochemical Exploration, Chinese Academy of Geological Sciences,

84 Jinguang Road, Langfang 065000, China,

e-mail: yangzheng@igge.cn

\section{Ян Чжэн,}

магистр,

ассистент инженера,

Институт геофизических и геохимических исследований Китайской академии геологических наук, 065000, г. Ланфран, ул. Цзиньгуан Роуд, 84, Китай,

e-mail: yangzheng@igge.cn

\section{Xiaomeng Cheng,}

Master's Degree,

Assistant Engineer,

Institute of Geophysical \& Geochemical Exploration, Chinese Academy of Geological Sciences,

84 Jinguang Road, Langfang 065000, China,

e-mail:309498905@qq.com

Чэн Сяомэн,

магистр,

ассистент инженера,

Институт геофизических и геохимических исследований Китайской академии геологических наук, 065000, г. Ланфран, ул. Цзиньгуан Роуд, 84, Китай,

e-mail: 309498905@qq.com

\section{Ziwan Chen,}

Master's Degree,

Senior Engineer,

Yunnan Institute of Geological Survey,

84 Renmin East Road, Kunming 650216, China,

e-mail: ChenZW_cdut@outlook.com

Чэнь Цзывань,

магистр,

старший инженер,

Юньнаньский институт Геологической службы,

650216 , г. Куньмин, ул. Жэньминь Ист Роуд, 84, Китай,

e-mail: ChenZW_cdut@outlook.com 


\section{Hua Zhang,}

Bachelor's Degree,

Senior Engineer,

Sichuan Geological Survey,

25 Renming Road, Chengdu 610081, China,

e-mail: 258155276@qq.com

Чжан Хуа,

бакалавр,

старший инженер,

Сычуаньская геологическая служба,

610081 , г. Чэнду, ул. Жэньминь Ист Роуд, 25, Китай, e-mail:258155276@qq.com

\section{Chunhu Mo,}

Bachelor's Degree,

Senior Engineer,

Guizhou Geological Survey,

171 Shilin West Road, Guiyang 550081, China,

e-mail:196189077@qq.com

\section{Мо Чуньху,}

бакалавр,

старший инженер,

Геологическая служба Гуйчжоу,

550081, г. Гуйян, ул. Шилинь Вест Роуд, 171, Китай, e-mail: 196189077@qq.com 